Prepared in Cooperation with the Great Lakes Commission

\title{
Uncertainty in the Great Lakes Water Balance
}

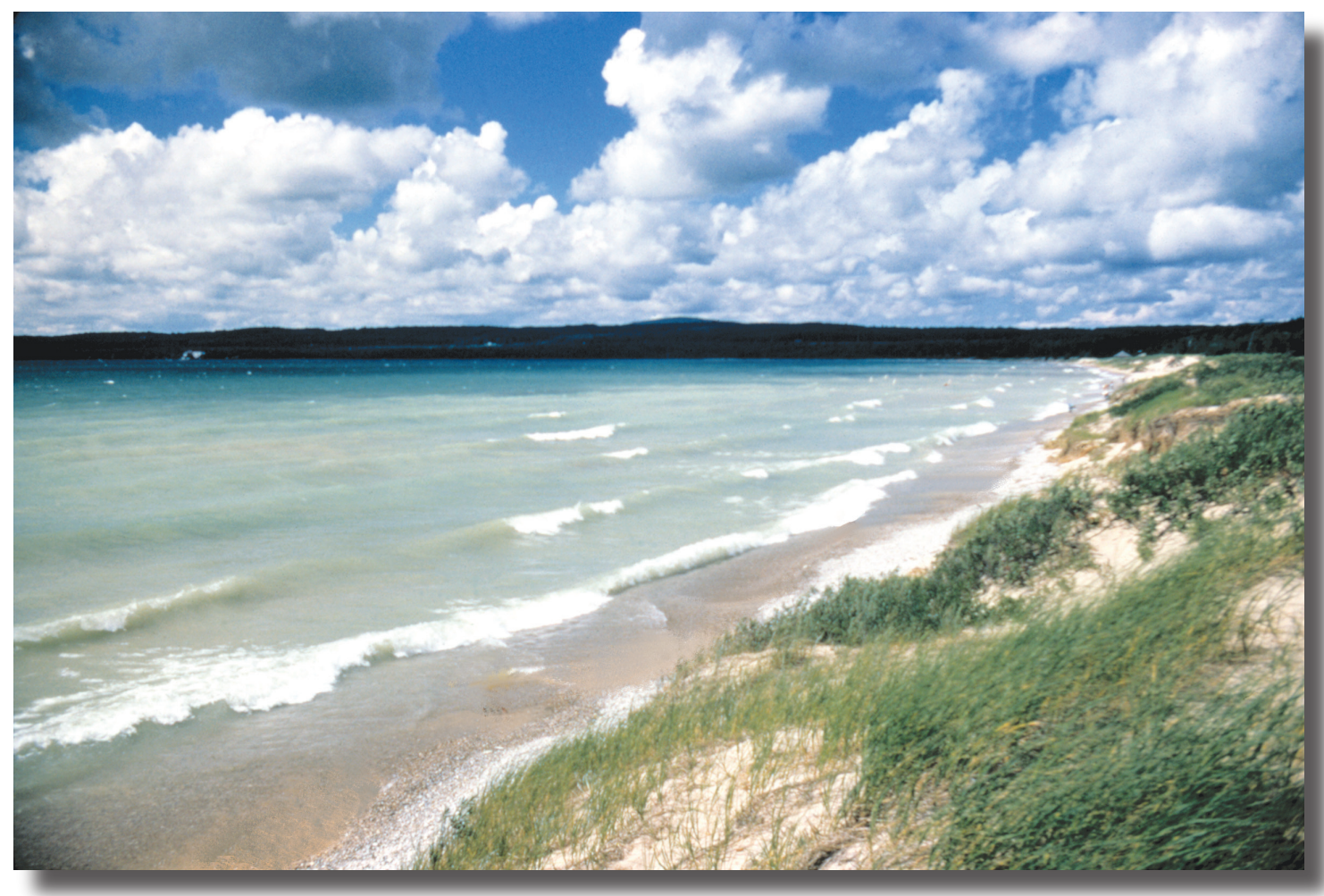

Scientific Investigations Report 2004-5100 
Cover Photograph. Lake Michigan beach near Petoskey, Michigan. (Photograph courtesy of Travel Michigan.) 


\section{Uncertainty in the Great Lakes Water Balance}

By Brian P. Neff and J.R. Nicholas

Prepared in cooperation with the Great Lakes Commission

Scientific Investigations Report 2004-5100

U.S. Department of the Interior

U.S. Geological Survey 


\title{
U.S. Department of the Interior \\ Gale A. Norton, Secretary \\ U.S. Geological Survey \\ Charles G. Groat, Director
}

U.S. Geological Survey, Reston, Virginia: 2005

For sale by U.S. Geological Survey, Information Services
Box 25286, Denver Federal Center
Denver, CO 80225
For more information about the USGS and its products:
Telephone: 1-888-ASK-USGS
World Wide Web: http://www.usgs.gov/

\author{
Any use of trade, product, or firm names in this publication is for descriptive purposes only and does not imply \\ endorsement by the U.S. Government. \\ Although this report is in the public domain, permission must be secured from the individual copyright owners to \\ reproduce any copyrighted materials contained within this report. \\ Suggested citation: \\ Neff, Brian P. , and Nicholas, J.R., 2005, Uncertainty in the Great Lakes Water Balance: \\ U.S. Geological Survey Scientific Investigations Report 2004-5100, 42 p.
}




\section{Contents}

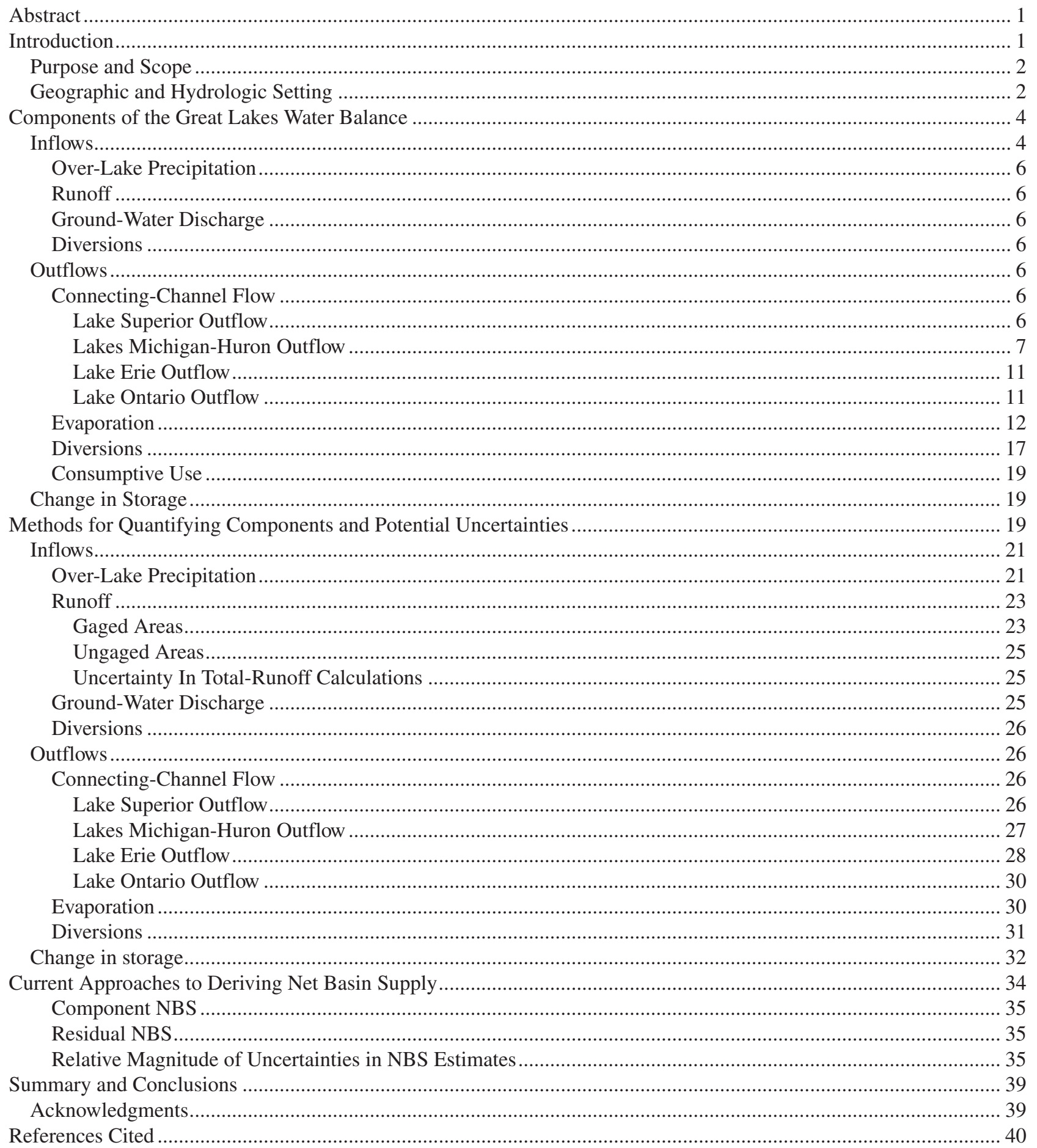




\section{Figures}

1-2. Maps showing:

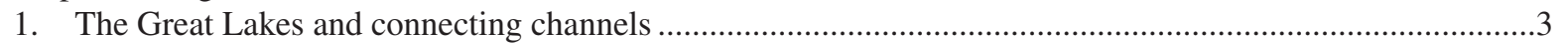

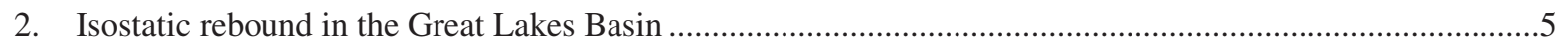

3. Graph showing:

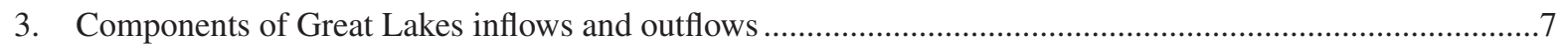

4-12. Maps showing:

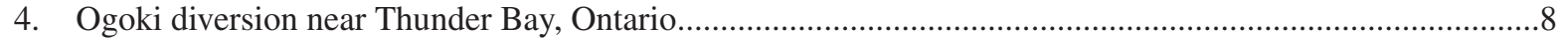

5. Long Lac diversion near Terrace Bay, Ontario ............................................................................................

6. St. Marys River near the twin cities of Sault Ste. Marie, Ontario, and Michigan .........................................10

7. Soo Navigation Locks at Sault Ste. Marie, Ontario, and Michigan ...........................................................11

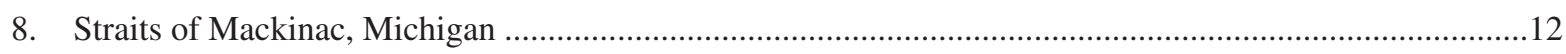

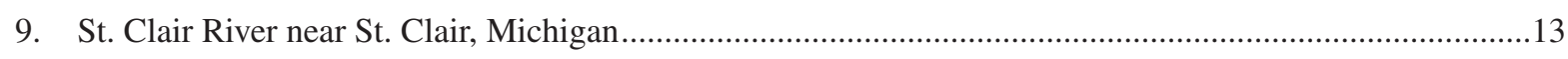

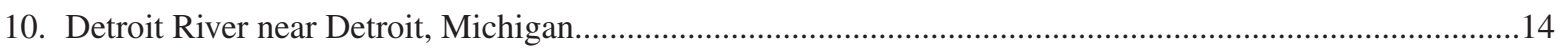

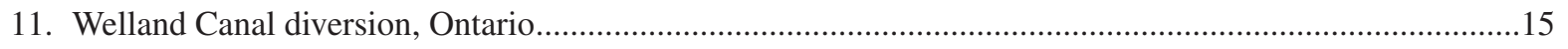

12. The New York State Barge Canal near Buffalo, New York........................................................................16

13. Diagram showing:

13. Flow pattern from Lake Erie to Lake Ontario ……..........................................................................17

14. Map showing:

14. St. Lawrence River downstream from Kingston, Ontario, to Lake St. Francis ............................................18

15. Graph showing:

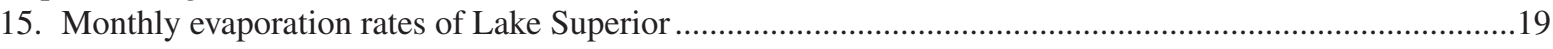

16-19. Maps showing:

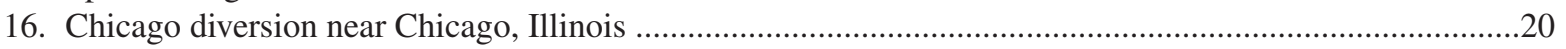

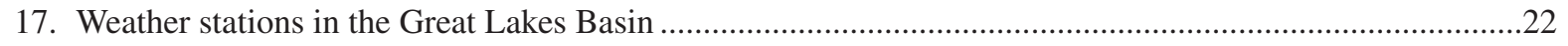

18. Stream-gage locations in the Great Lakes Basin ..................................................................................

19. Locations of lake level gages in the Great Lakes Basin.......................................................................3

20-21. Graphs showing:

20. Total uncertainty in monthly net basin supply estimates for each method and each Great Lake, expressed as flow rate

21. Potential range of percentage uncertainty in monthly net basin supply estimates for each method and each Great Lake. 


\section{Tables}

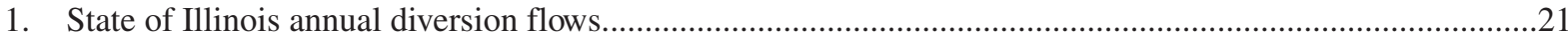

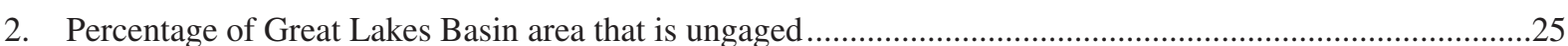

3. Summary of monthly component and net basin supply (NBS) uncertainty for Lake Superior......................36

4. Summary of monthly component and net basin supply (NBS) uncertainty for Lakes Michigan-Huron ........36

5. Summary of monthly component and net basin supply (NBS) uncertainty for Lake Erie..........................37

6. Summary of monthly component and net basin supply (NBS) uncertainty for Lake Ontario.....................37

7a. Summary of net basin supply (NBS) uncertainty, expressed as a percent of long term average monthly NBS

7b. Summary of net basin supply (NBS) uncertainty, expressed in cubic feet per second

\section{Conversion Factors}

\section{Inch/Pound to SI}

\begin{tabular}{|c|c|c|}
\hline Multiply & By & To obtain \\
\hline \multicolumn{3}{|c|}{ Length } \\
\hline foot $(\mathrm{ft})$ & 0.3048 & meter $(\mathrm{m})$ \\
\hline foot $(\mathrm{ft})$ & 304.8 & millimeter (mm) \\
\hline mile (mi) & 1.609 & kilometer (km) \\
\hline \multicolumn{3}{|c|}{ Area } \\
\hline square mile $\left(\mathrm{mi}^{2}\right)$ & 2.590 & square kilometer $\left(\mathrm{km}^{2}\right)$ \\
\hline \multicolumn{3}{|c|}{ Volume } \\
\hline cubic mile $\left(\mathrm{mi}^{3}\right)$ & 4.168 & cubic kilometer $\left(\mathrm{km}^{3}\right)$ \\
\hline \multicolumn{3}{|c|}{ Flow rate } \\
\hline cubic foot per second $\left(\mathrm{ft}^{3} / \mathrm{s}\right)$ & 0.02832 & cubic meter per second $\left(\mathrm{m}^{3} / \mathrm{s}\right)$ \\
\hline
\end{tabular}

Temperature in degrees Celsius $\left({ }^{\circ} \mathrm{C}\right)$ may be converted to degrees Fahrenheit $\left({ }^{\circ} \mathrm{F}\right)$ as follows:

${ }^{\circ} \mathrm{F}=\left(1.8 \times{ }^{\circ} \mathrm{C}\right)+32$

Temperature in degrees Fahrenheit $\left({ }^{\circ} \mathrm{F}\right)$ may be converted to degrees Celsius $\left({ }^{\circ} \mathrm{C}\right)$ as follows:

${ }^{\circ} \mathrm{C}=\left({ }^{\circ} \mathrm{F}-32\right) / 1.8$ 


\section{Abbreviations and Acronyms}

ADCP - Acoustic Doppler Current Profiler

AVM - Acoustic Velocity Meter

BOM - Beginning-of-Month

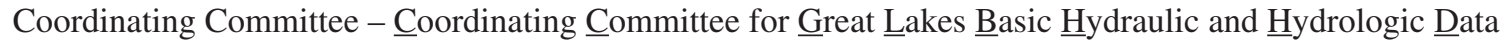
(CCGLBHHD)

CSSC - Chicago Sanitary and Ship Canal

IJC - International Joint Commission

MEDS - Marine Environmental Data Service

MRCC - Midwestern Regional Climate Center

MSC - Meteorological Survey of Canada (formerly known as the Water Survey of Canada)

NBS - Net Basin Supply

NOAA - National Oceanic and Atmospheric Administration

NOS - U.S. National Ocean Service (a division of NOAA)

NWS - U.S. National Weather Service

NYPA - New York Power Authority

OPG - Ontario Power Generation

TSC2 - Technical Subcommittee 2

WRMDSS - Water Resources Management Decision Support System 


\title{
Uncertainty in the Great Lakes Water Balance
}

\author{
By Brian P. Neff and J. R. Nicholas
}

\section{Abstract}

This report describes the Great Lakes hydrologic system and methods used to quantify individual components of the water balance. Potential sources of uncertainty are identified and, where appropriate, alternate or additional data, models, and estimation methods suitable for reducing uncertainties are discussed. Finally, approximate uncertainties of all components are identified, compared, and assessed within the context of net basin supply. Results indicate that average uncertainties in monthly estimates of individual water-balance components may range from 1.5 percent to 45 percent. These uncertainties may cause uncertainties in monthly net basin supply estimates of approximately $2,600 \mathrm{ft}^{3} / \mathrm{s}$ to $33,500 \mathrm{ft}^{3} / \mathrm{s}$ for individual Great Lakes.

\section{Introduction}

The Great Lakes are a profound element of the North American continent. Resources within and around these lakes are important to the cultural heritage of the continent, are esthetically pleasing, and support thriving economies based largely on recreation and manufacturing. Additionally, the Great Lakes and their connecting channels are essential watersupply and power-generating resources that support extensive economic and urban development throughout the region.

The Great Lakes are an immense hydrologic system. To gain some perspective of their size, consider that the water contained in the Great Lakes could cover the continents of North America, South America, and Africa to a depth of more than $1 \mathrm{ft}$. Additionally, the bottom of Lake Superior is $731 \mathrm{ft}$ below sea level. Water entering Lake Superior will take an estimated 191 years to travel to Lake Huron (Government of Canada and U.S. Environmental Protection Agency, 1995, p. 3). The surface of the Great Lakes spans approximately 7.5 degrees of latitude, or nearly $575 \mathrm{mi}$. This is roughly equal to the same latitudinal change between the cities of Cleveland, Ohio, and Atlanta, Georgia. Longitudinally, the Great Lakes extend 16 degrees, or approximately $900 \mathrm{mi}$. The volume and surface size of the lakes have significant implications with regard to variability in the hydrologic system throughout the Great Lakes region.

Coping with fluctuating lake levels is an unavoidable facet of living and working on or near the Great Lakes. Rising and falling lake levels affect shipping, recreational boating, and water supply, and damage coastline through flooding and erosion. To minimize the damage resulting from fluctuating lake levels, decision makers must understand the processes that cause these fluctuations and manage activities accordingly. One way to evaluate these processes is to study the water balance of the Great Lakes.

A water balance is an accounting of all water entering and leaving a given body of water, for a given period of time. Mathematically, this can be expressed as "inflow equals outflow plus change in storage". A water balance is quantified through the evaluation and accounting of these three components. Researchers have quantified water balances for many decades, and hundreds of water-balance studies have been done. However, uncertainties vary dramatically in water balances and are not addressed in most studies. For a review of recent literature on the subject, the reader is directed to $\mathrm{Xu}$ and Singh (1998).

One useful application of the water-balance approach is to quantify net basin supply (NBS) - the net amount of water entering each Great Lake, not counting the supply of water from upstream Great Lakes. One feature of NBS is that it can be computed two ways, by the component method or the residual method (Croley and others, 2001; Lee, 1992). Each method allows the researcher some freedom to evaluate select hydrologic parameters to derive NBS, an important feature for assessing uncertainty in current Great Lakes NBS estimates.

Flows into and out of the Great Lakes and the levels of the lakes are measured or calculated at hundreds of locations throughout the basin. Although lake levels are measured directly, most flows are based on estimates or measurements of other parameters and are computed using simple equations. Many agencies maintain a current understanding of the Great Lakes-St. Lawrence System through continuous and long-term monitoring. Funding sources for monitoring are diverse, ranging from federal governments to state, provincial, and municipal agencies and the private sector.

In this study, the term "uncertainty" is used qualitatively to describe errors and biases associated with measurements, calculations, and estimates. All measurements and calculations have uncertainty associated with them. Uncertainty does not necessarily indicate errors or flaws in monitoring. In some cases, uncertainty in a measurement or calculation may be present despite state-of-the-art instrumentation or estimation 
methods. In other cases, uncertainty may be reduced by additional monitoring or by application of more advanced instrumentation and estimation methods. The degree of uncertainty can vary as a function of the magnitude of physical process being measured, calculated, or estimated.

In June 2001, eight U.S. state governors and two Canadian province premiers signed an Annex to the 1985 Great Lakes Charter. Annex 2001 calls for, among other things, hydrologic data and information to support a new decision standard regarding proposals to withdraw water from the Great Lakes Basin. Uncertainty in calculations of flows and levels is closely linked to Great Lakes Charter Annex issues. If part of the system is poorly understood-has high uncertainty-then predicting the effects of a proposed withdrawal on flows, levels, and the ecosystem will be difficult. Conversely, if part of the system is well understood, then effects of a withdrawal on levels or flows can be predicted and used to evaluate ecological impacts. Current (2004) monitoring networks were not designed for the specific purpose of providing such decision support. The U.S. Geological Survey, in cooperation with the Great Lakes Commission, conducted a study to assess uncertainty in the Great Lakes water balance and address important questions regarding the status of existing hydrologic monitoring networks. Information from the study can help managers determine the usefulness of existing monitoring networks to Annex 2001 issues.

\section{Purpose and Scope}

The purpose of this report is to describe uncertainty in the Great Lakes water balance. Specifically, this report

- describes the Great Lakes hydrologic system,

- describes how water-balance components are quantified,

- identifies potential sources of uncertainty in these estimates,

- determines the approximate uncertainty in estimates of individual components,

- compares uncertainties of each component, and

- evaluates how these uncertainties affect the reliability of NBS estimates.

There are no published uncertainty calculations associated with most of the flows and levels of the Great Lakes. Therefore, TSC 2 used its best professional judgment to estimate ranges of uncertainty for flows and levels. These ranges are presented for the purpose of illustrating how well the hydrology of the Great Lakes-St. Lawrence System is understood.

Throughout this report, uncertainties are discussed within the context of monthly data and monthly NBS estimates. This context is used because the Great Lakes water balance is most commonly described on a monthly time scale, to calculate NBS. It is not known if monthly data, or if the concept of NBS, is well suited to the information needs of Annex 2001.

This report is a product of Technical Subcommittee 2 (TSC2) of the Water Resources Management Decision Support System (WRMDSS) project supported by the Great Lakes Protection Fund. TSC2 was charged with providing a status assessment of water-resources information and availability. Most of the work of TSC2 was designed to evaluate the quantity and quality of water-resources data and information on a lakewide or systemwide scale. Specifically, the work and other publications resulting from TSC2 focused on flows and levels in the context of net basin supplies to each Great Lake. Additional information is available from two other project reports: "The Great Lakes Water Balance: Data Availability and Annotated Bibliography of Selected References" (Neff and Killian, 2003) and "Great Lakes Monthly Hydrologic Data" (Croley and others, 2001).

\section{Geographic and Hydrologic Setting}

The Great Lakes-St. Lawrence System comprises (1) Lakes Superior, Michigan, Huron, Erie, and Ontario, (2) their connecting channels, St. Marys River, St. Clair River, Lake St. Clair, Detroit River, and Niagara River, and (3) the St. Lawrence River, which carries the waters of the Great Lakes to the Atlantic Ocean (fig. 1). The system also includes several constructed canals and control structures that either interconnect Great Lakes or connect the Great Lakes to other river systems. The Great Lakes Basin, including the international section of the St. Lawrence River upstream from Cornwall, Ontario/Massena, New York, covers about 295,000 $\mathrm{mi}^{2}$. The basin includes parts of eight U.S. states and one Canadian province: Minnesota, Wisconsin, Illinois, Indiana, Michigan, Ohio, Pennsylvania, New York, and Ontario. Fifty-nine percent of the basin is in the United States; 41 percent is in Canada. The basin is about $700 \mathrm{mi}$ long measured north to south and about $900 \mathrm{mi}$ long measured west to east, at the outlet of Lake Ontario at Cornwall, Ontario/Massena, New York. The St. Lawrence River downstream from Cornwall, Ontario/Massena, New York, is about $540 \mathrm{mi}$ long and flows through the state of New York and provinces of Ontario and Quebec.

In 1990, the population of the Great Lakes Basin was about 33 million, not including Chicago. About 52 percent of the basin is forested; 35 percent is in agricultural uses; 7 percent is urban/ suburban; and 6 percent is in other uses. Major commerce and industries in the Great Lakes Basin are manufacturing, tourism, and agriculture, at about $\$ 308$ billion, $\$ 82$ billion, and $\$ 48$ billion U.S. per year, respectively (Great Lakes Commission, 2003, p. 28).

Dredging, control structures, locks, dams, hydroelectric facilities, canals, and diversions have altered the hydrology of the Great Lakes-St. Lawrence System. Dredging and control structures have had the largest impacts. For instance, the dredging of the St. Clair River from 1880 to 1965 permanently lowered Lake Michigan and Lake Huron by 15.8 in (International Joint Commission, 1999). Control structures at the outlets of Lake 


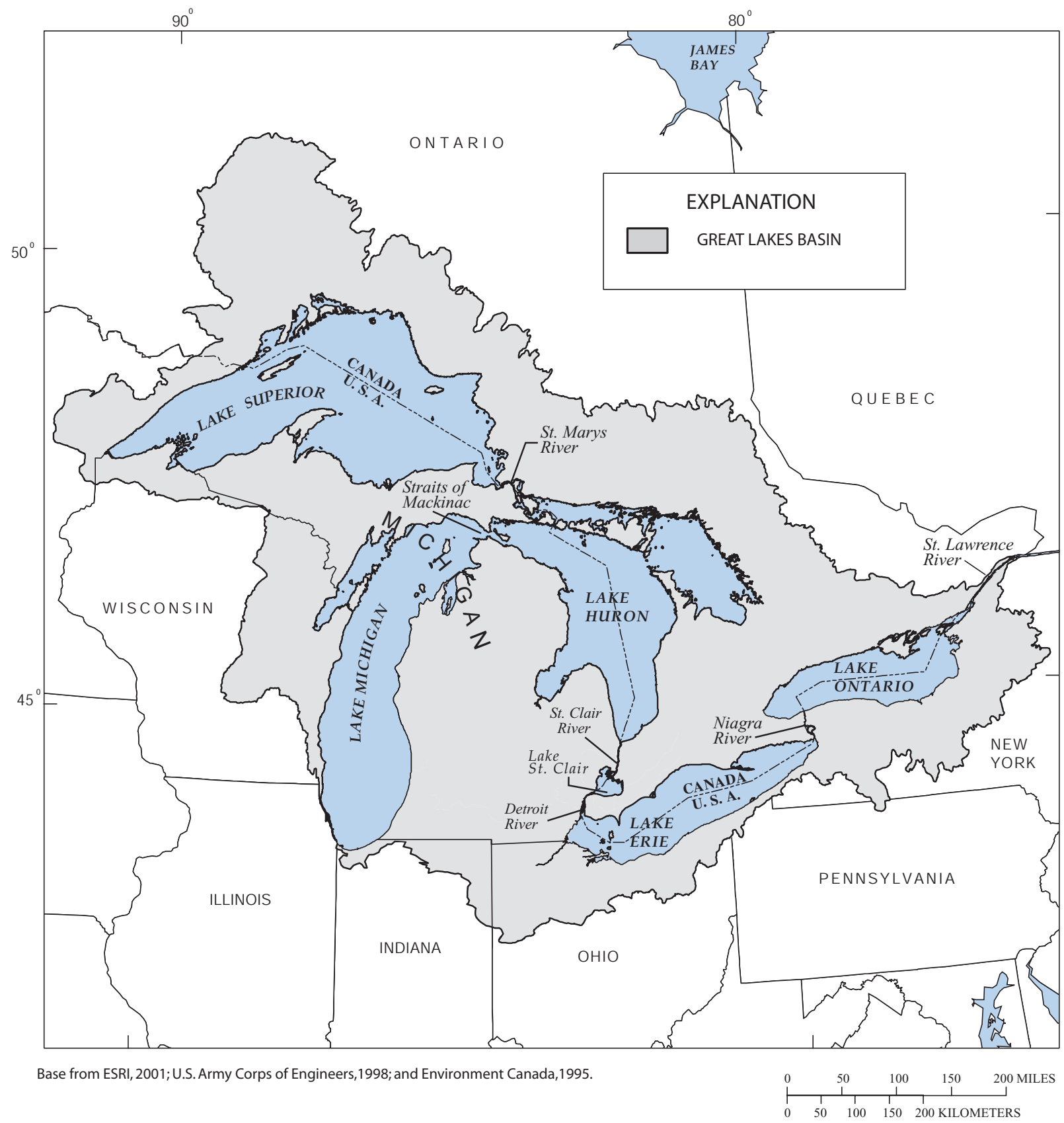

Figure 1. The Great Lakes and connecting channels. 
Superior and Lake Ontario keep the levels of these lakes regulated within a range that is smaller than the range of levels that would occur under natural outflow conditions.

The Great Lakes and their connecting channels cover approximately 32 percent of the entire Great Lakes-St. Lawrence River Basin upstream from Cornwall/Massena. The volume of each Great Lake and the land and water area of their individual basins are varied. For example, total area of the Lake Superior Basin is $81,000 \mathrm{mi}^{2}$. Surface area of Lake Superior is $31,700 \mathrm{mi}^{2}$, or 39 percent of its entire basin area. In contrast, surface area of Lake Ontario, 7,340 $\mathrm{mi}^{2}$, is only 23 percent of the Lake Ontario Basin (Coordinating Committee on Great Lakes Basic Hydraulic and Hydrologic Data, ${ }^{1}$ 1977). The proportion of a lake's basin that consists of lake surface directly affects the amount and timing of over-lake precipitation and runoff from the basin's tributary streams, as well as the amount of water lost from the lake surface through evaporation.

The climate of the Great Lakes Basin varies widely according to its long north-south extent and the effects of the Great Lakes on nearshore temperatures and precipitation. Precipitation is distributed relatively uniformly throughout the year, but it is variable from west to east across the basin. Mean annual snowfall is much more variable because of temperature differences from north to south and in snowbelt areas near the east side of the Great Lakes. Also, wind is an important component of the Great Lakes climate. During all seasons, the predominant wind direction has a westerly component. In fall and winter, very strong winds are common in nearshore areas, driven in part by temperature difference between the lakes and the air moving over them.

Fluctuations in Great Lakes water levels result from several natural factors and human influences. Levels of the Great Lakes depend on their storage capacity, outflow characteristics of the outlet channels, operating procedures of the regulatory structures, and the amount of water supply received by each lake. The primary natural factors affecting lake levels are over-lake precipitation, runoff from the drainage basin, evaporation from the lake surface, inflow from upstream lakes, and outflow to downstream lakes. Human factors include diversions into or out of the basin, consumption of water, dredging of outlet channels, and regulation of outflows.

There are three types of water-level fluctuations on the Great Lakes. First are long-term fluctuations, occurring on a time scale of many years, which result from persistent low or high water supplies. Second are seasonal fluctuations of the Great Lakes levels, occurring on a sub-annual time scale, which reflect variation in the annual hydrologic cycle. Seasonal waterlevel fluctuations are characterized by higher NBS during spring and early summer and lower NBS during the remainder of the year. Third are short-term fluctuations in water-level (lasting from a less than an hour to several days) that happen as water levels rise (set-up), fall (set-down), or oscillate (seiche) due to

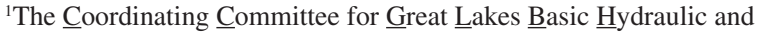
Hydrologic $\underline{\text { Data }}$ (CCGLBHHD) will be referred to hereafter as simply the "Coordinating Committee."
}

effects of wind and differences in barometric pressure over the lake surface.

Short-term changes in outflows can result from storm surge or seiches. Storm surge, or wind set-up, is the phenomenon of a local rise in water level caused by winds pushing water to the downwind side of a lake. Seiche is a distinct phenomenon resulting when water levels of the lake oscillate as water rushes back and forth across the lake in response to sudden weather changes, such as in wind direction and barometric pressure (Manninen and Gauthier, 1999; Government of Canada and U.S. Environmental Protection Agency, 1995). If water levels increase at the outlet end of the lake, outflows can temporarily increase. In contrast, if levels decline at the outlet end of the lake, outflows can be reduced.

Ice formation and ice jams slow streamflow in outlet rivers of the lakes during winter. These conditions are not predictable for any specific winter, either as to severity or exact timing of their occurrence. Aquatic plant growth in the rivers during summer also slows outflow. This process varies from river to river.

Over time, water levels throughout the Great Lakes also are affected by isostatic rebound. Isostatic rebound is a gradual rising of the Earth's crust caused by the removal of relatively heavy glaciers that once covered the Great Lakes-St. Lawrence River region. Rates of isostatic rebound are not uniform; generally, rates of rebound around Lakes Superior and Ontario are greater than those around Lakes Michigan-Huron and Erie. Water levels are affected as lake basins tilt by a gradual rising of their northeastern rims. As time progresses, water levels along shores south and west of a lake's outlet are rising with respect to overall average lake level, whereas water levels along shores north and east of the outlet are receding with respect to land (fig. 2).

\section{Components of the Great Lakes Water Balance}

Before beginning a detailed discussion on quantification of water-balance components and their potential uncertainties, a thorough qualitative description of each component of the water balance is in order.

\section{Inflows}

In this report, the term "inflows" refers to water entering each Great Lake. Inflows include (1) over-lake precipitation, (2) runoff, (3) ground-water seepage into the Great Lakes, (4) diversion of water into the Great Lakes, and (5) flow from the connecting channels. As expressed mathematically,

$$
\text { Inflows }=P+R+G W_{i n}+D_{i n}+C C_{i n},
$$

where $P$ is precipitation falling directly on the lake, $R$ is runoff, $G W_{\text {in }}$ is ground-water inflow (net discharge), $D_{\text {in }}$ is diversions into the Great Lakes, and $C C_{i n}$ is connecting-channel inflow. Connecting-channel inflow is discussed in the outflows section. 


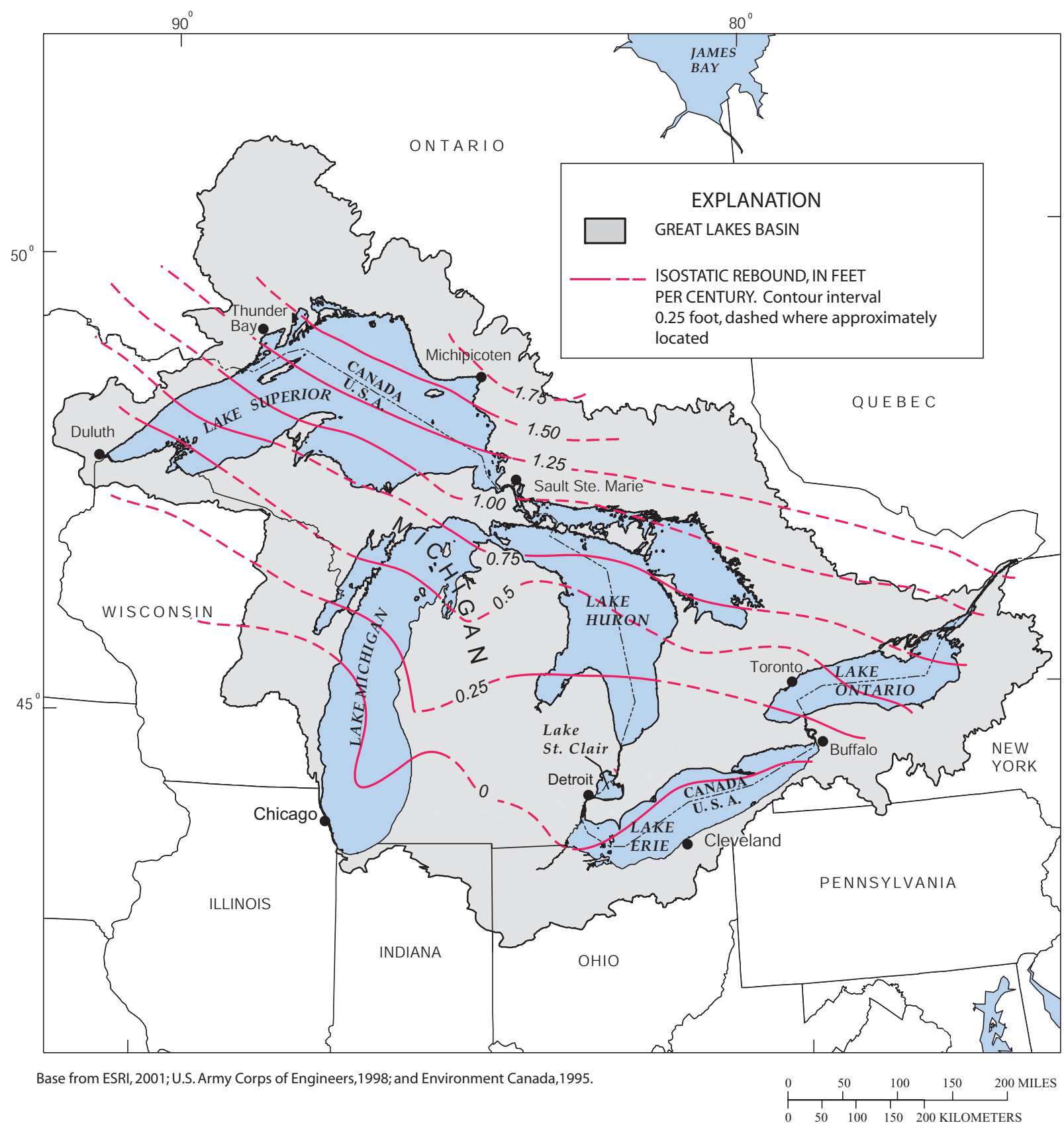

Figure 2. Isostatic rebound in the Great Lakes Basin. (Adapted from Clark and Persoage, 1970, Larsen, 1987.) 


\section{Over-Lake Precipitation}

In many water-balance studies, precipitation falling directly on the surface of a water body is a negligible component of the hydrologic cycle. However, the Great Lakes cover an area of approximately $94,250 \mathrm{mi}^{2}$, about one-third of the total area of the Great Lakes Basin (Coordinating Committee, 1977). According to data presented by Croley and others (2001), the amount of water that falls directly on the surface of the Great Lakes is greater than all of the water that enters the lakes through runoff (fig. 3 ).

\section{Runoff}

Much of the precipitation that falls in the Great Lakes Basin drains into streams that discharge into the lakes. Thousands of streams drain approximately $200,000 \mathrm{mi}^{2}$ of land area and feed directly into the Great Lakes. Direct overland flow to the Great Lakes also is a component of runoff. According to data presented by Croley and others (2001), the amount of water that enters the Great Lakes as runoff is slightly less than the amount of water that enters the lakes through over-lake precipitation (fig. 3).

\section{Ground-Water Discharge}

Some of the precipitation that falls on the Great Lakes Basin land area infiltrates the soil and becomes ground water. Most ground water flows to and discharges into the many tributary streams to the Great Lakes. Some of this ground water, however, discharges directly into the Great Lakes through the lakebed. A few estimates of ground-water discharge into the Great Lakes have been made, and these are summarized by Grannemann and Weaver (1999).

\section{Diversions}

Two large diversions of water into the Great Lakes constitute a significant part of the water balance. The Ogoki and Long Lac diversions redirect water that would normally flow into Hudson Bay by way of the Albany River to the Lake Superior Basin (figs. 4 and 5). The Ogoki diversion moves water through the Little Jackfish River, Lake Nipigon, and the Nipigon River into Lake Superior at a point $60 \mathrm{mi}$ east of Thunder Bay. Three hydroelectric plants on the Nipigon River use this diverted water to generate power. The Long Lac diversion redirects water through Long Lake and the Aguasabon River into Lake Superior near Terrace Bay. The Long Lac diversion provides water for a hydroelectric plant near Terrace Bay and for pulpwood-log conveyance down the river. The Ogoki diversion redirects a drainage basin more than 3 times larger than that of the Long Lac diversion. Together, the Long Lac and Ogoki diversions increase water supply to the Lake Superior Basin by about $5,580 \mathrm{ft}^{3} / \mathrm{s}$. These two diversions into the Great Lakes Basin are more than 60 percent greater than all current diversions out of the Great Lakes Basin (International Joint Commission, 1999, p. 10). Other diversions of water into the Great Lakes Basin are relatively small and not discussed herein (International Joint Commission, 1999, p. 10).

\section{Outflows}

In this report, "outflows" refers to water leaving each Great Lake by way of (1) evaporation, (2) flow through connecting channels, (3) diversion of water away from the Great Lakes, and (4) consumptive use of Great Lakes water. Consumptive use is water withdrawn or withheld from the Great Lakes Basin and not returned. As expressed mathematically,

$$
\text { Outflows }=C C_{\text {out }}+E+D_{\text {out }}+C_{\text {use }}
$$

Where $\mathrm{CC}_{\text {out }}$ is connecting-channel outflow, $\mathrm{E}$ is evaporation from the lake surface, $\mathrm{D}_{\text {out }}$ is diversions away from the Great Lakes, and $\mathrm{C}_{\text {use }}$ is consumptive use of Great Lakes water.

\section{Connecting-Channel Flow}

Connecting channels are large, short rivers that flow from lake to lake, and to the Atlantic Ocean. Flow through each connecting channel increases as the water level rises in the upstream lake, but the size and position of each connecting channel restricts flow out of a lake as its water level rises. This constraint limits the outflow from the Great Lakes, allowing the lakes to store large amounts of water in times of above-average water supply and then release that water much later when supplies are likely to be lower. This results in a hydrologic system that is naturally resistant to large variation in river flows. The maximum St. Lawrence River flow (at Massena) of $356,700 \mathrm{ft}^{3} / \mathrm{s}$ is only 2.3 times the all-time minimum flow of $154,000 \mathrm{ft}^{3} / \mathrm{s}$. In contrast, the historical peak flow of the Mississippi River at Arkansas City, Arkansas, is approximately 25 times the all-time minimum flow of $88,200 \mathrm{ft}^{3} / \mathrm{s}$.

As a component of the water balance, connecting-channel flows vary in magnitude from lake to lake (fig. 3). According to data reported by Croley and others (2001), connecting-channel flow represented 59 percent of all water outflows (and 0 percent of all water inflows) from Lake Superior for 1948-98. In contrast, connecting-channel flow represented 95 percent of all water outflows (and 77 percent of all water inflows) from Lake Ontario for the same period.

The influence of evaporation and runoff on connecting-channel flow is quite small in comparison to total volume of flow. For this reason, flows are commonly defined at one point on each connecting channel and not distinguished between outflow of one lake and inflow of the next lake.

\section{Lake Superior Outflow}

Water flows out of Lake Superior and into Lake Huron through the St. Marys River (fig. 6). Lake Superior outflows are regulated at the twin cities of Sault Ste. Marie, Ontario and Michi- 


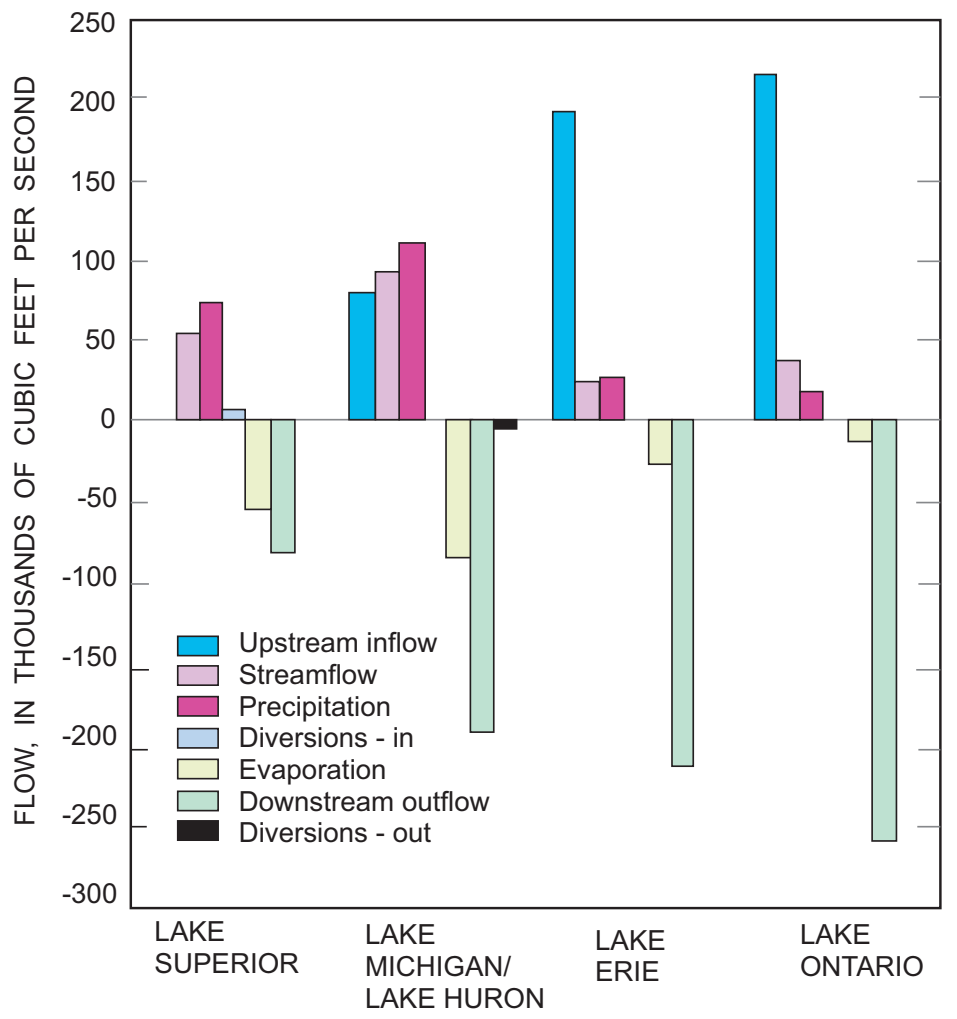

Figure 3. Components of Great Lakes inflows and outflows. (Modified from Great Lakes Commission, 2003.) Positive values denote inflows, and negative values denote outflows for each lake.

gan, by the International Joint Commission (IJC) International Lake Superior Board of Control. Actual outflow is a combination of flows through three hydropowerplants, the Soo Navigation Locks, the international dam known as the Compensating Works, and minor amounts of water used for wildlife, domestic, and commercial use (fig. 7; Neff and Killian, 2003). The Board of Control sets Lake Superior outflow each month according to IJC Regulation Plan 1977A. This plan takes into consideration water levels of Lake Superior and Lakes Michigan-Huron. The objective in adjusting flows is to help maintain lake levels near their long-term seasonal averages. Since records have been kept, monthly Lake Superior outflows have averaged 75,000 ft $3 / \mathrm{s}$.

Average monthly flows have been as high as $132,000 \mathrm{ft}^{3} / \mathrm{s}$ and as low as $41,000 \mathrm{ft}^{3} / \mathrm{s}$ (according to data presented by Croley and others, 2001).

\section{Lakes Michigan-Huron Outflow}

Lakes Michigan and Huron are connected hydraulically by the wide and deep Straits of Mackinac (fig. 8). The water level of both lakes is virtually identical because of this connection. As yet, few data describe direct measurements of flow through the
Straits of Mackinac, and the three-dimensional pattern of flow through this connection between the lakes is possibly complex. Evaluation of the water balances of the two lakes shows that net flow direction is from Lake Michigan to Lake Huron in most years. For 1948-99, average flow from Lake Michigan to Lake Huron was approximately $49,000 \mathrm{ft}^{3} / \mathrm{s}$, based on water-balance data reported by Croley and others (2001). Typically, flow through the St. Clair River is considered to be outflow of both Lake Michigan and Lake Huron.

Water flows out of Lakes Michigan-Huron through the St. Clair-Detroit River waterway (figs. 9 and 10). Flows through the two rivers are determined primarily by size and dimensions of their channels and by levels of Lakes Michigan-Huron, St. Clair, and Erie. The St. Clair and Detroit River channels are wide and deep enough to permit shipping in their upper reaches, but they have been dredged to a depth of $27 \mathrm{ft}$ in their lower reaches to improve navigation through the Great Lakes waterway. Lake St. Clair has an average depth of $11 \mathrm{ft}$ and a maximum depth of $21 \mathrm{ft}$, except for a 27-ft-deep channel that has been dredged across this body of water (Coordinating Committee, 1988, p. 9). 


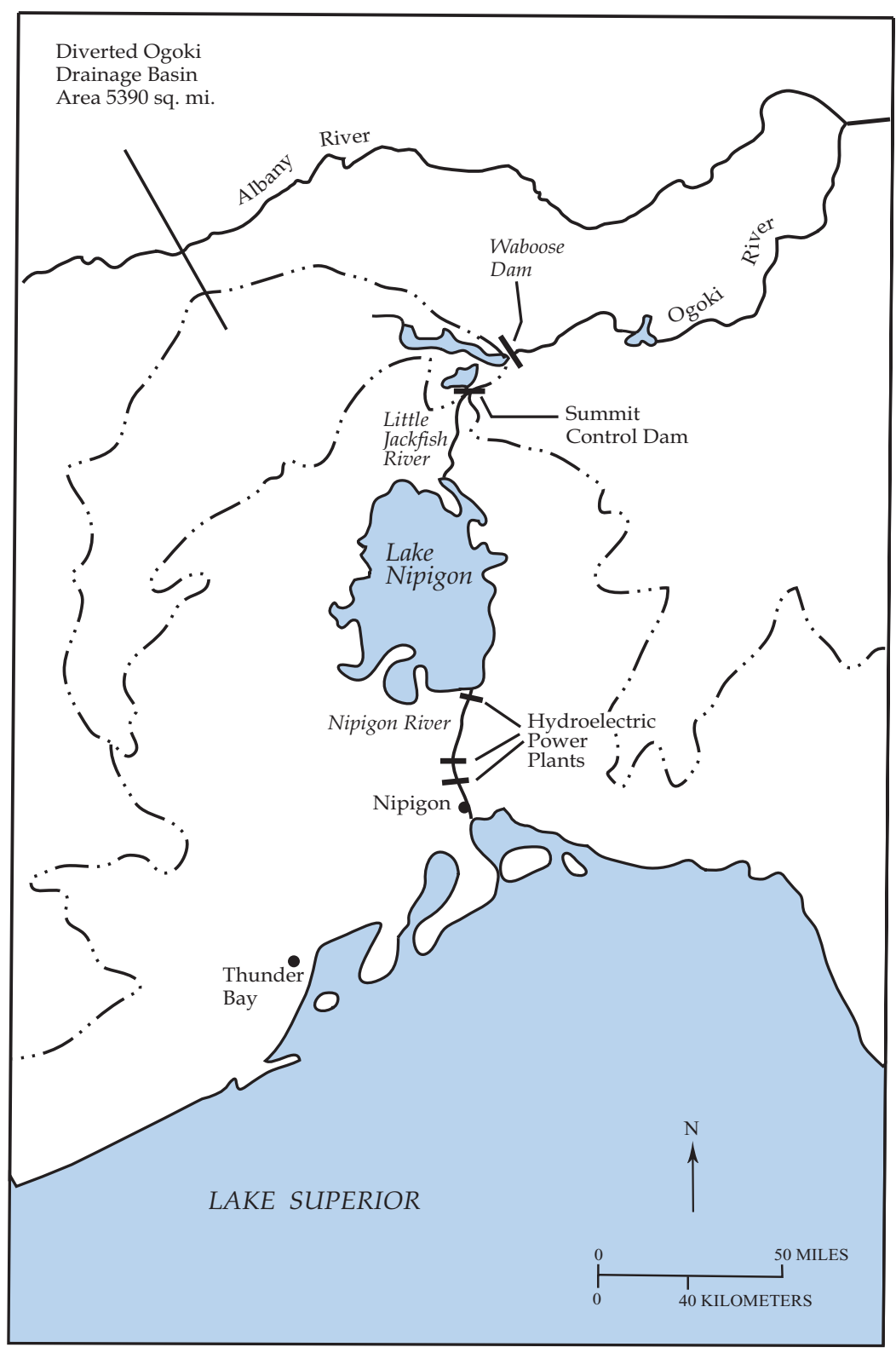

Base from the International Joint Commission, 1985.

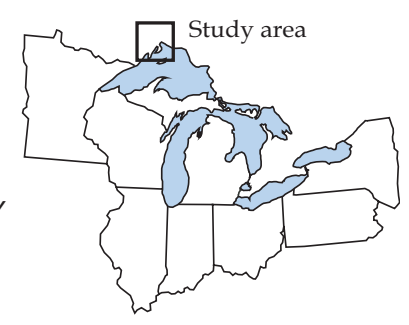

Figure 4. Ogoki diversion near Thunder Bay, Ontario. 


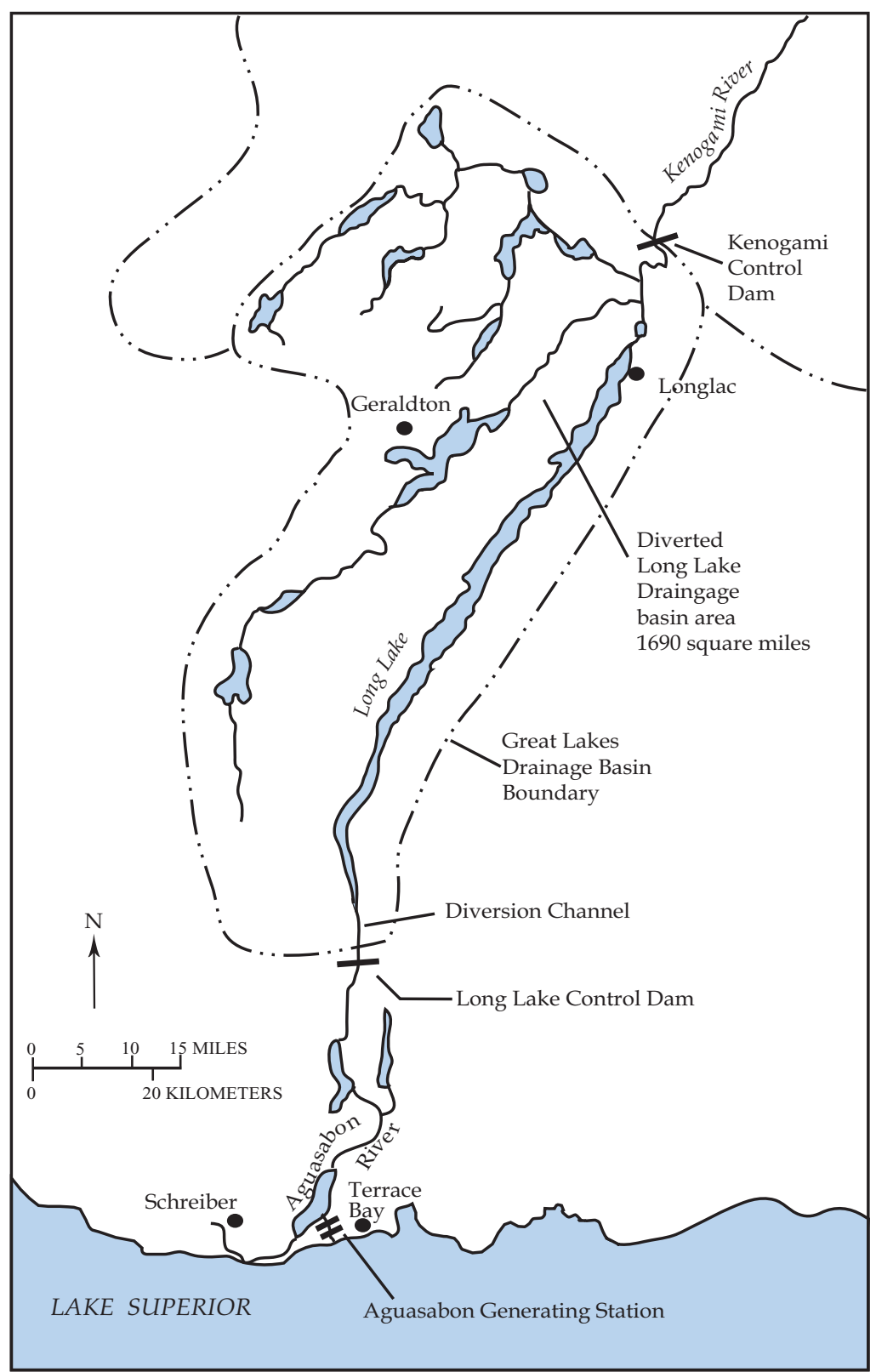

Base from the International Joint Commission, 1985.

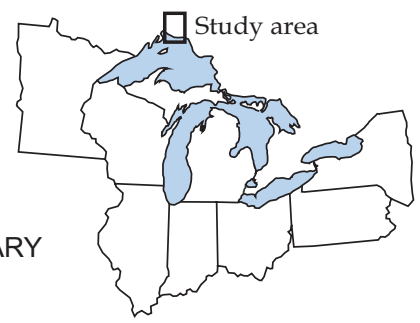

Figure 5. Long Lac diversion near Terrace Bay, Ontario. 


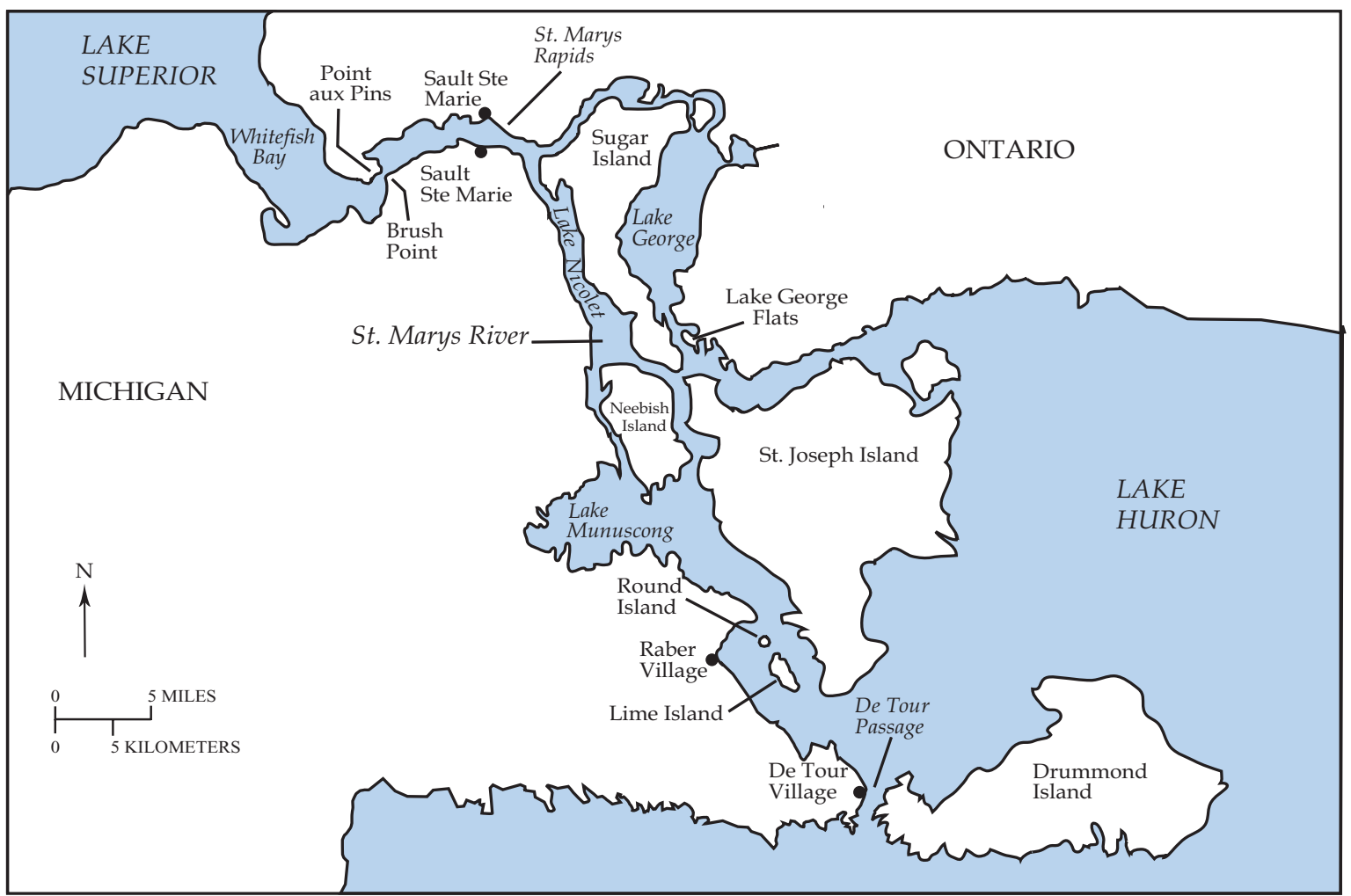

Base from Coordinating Committee on Great Lakes Basic Hydraulic and Hydrologic Data, 1994.

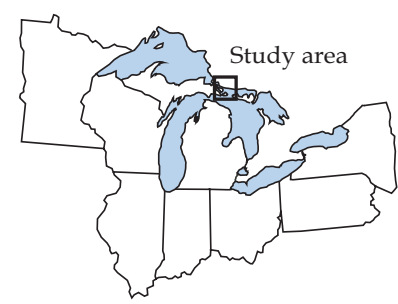

Figure 6. St. Marys River near the twin cities of Sault Ste. Marie, Ontario, and Michigan.

Two hydrologic phenomena can significantly affect Lakes Michigan-Huron outflow for short periods. First, the presence of ice affects St. Clair and Detroit River flows directly by slowing flow of water. Ice floes also can accumulate and form an ice jam, which retards river flow for a few hours or days to as much as several weeks or more. Ice jams are especially common to the St. Clair River delta and can reduce flows by as much as 65 percent (Derecki and Quinn, 1986). Compared to the pre-1930 flow regime, ice retardation of river flows has been reduced significantly by dredging (Coordinating Committee, 1988, p. 8).

Second, wind set-up and seiche on Lake Erie significantly affect the timing of Detroit River flows. Wind set up on Lake Erie causing water levels 3-4 ft higher than normal at one end is not uncommon. The Detroit River descends only about
$3 \mathrm{ft}$ in the $32 \mathrm{mi}$ it flows from Lake St. Clair to Lake Erie. This makes Detroit River flows particularly sensitive to wind set-up and seiche on Lake Erie. When wind set-up occurs in conjunction with ice jams on the St. Clair River, flow of the Detroit River can, and actually does, reverse direction (Quinn, 1988; Quinn and Derecki, 1990). Since records have been kept, monthly St. Clair and Detroit River flows have averaged $188,000 \mathrm{ft}^{3} / \mathrm{s}$. Average monthly flows have been as high as $272,000 \mathrm{ft}^{3} / \mathrm{s}$ and $250,000 \mathrm{ft}^{3} / \mathrm{s}$ and as low as $106,000 \mathrm{ft}^{3} / \mathrm{s}$ and $112,000 \mathrm{ft}^{3} / \mathrm{s}$, respectively (according to data reported by Croley and others, 2001). 


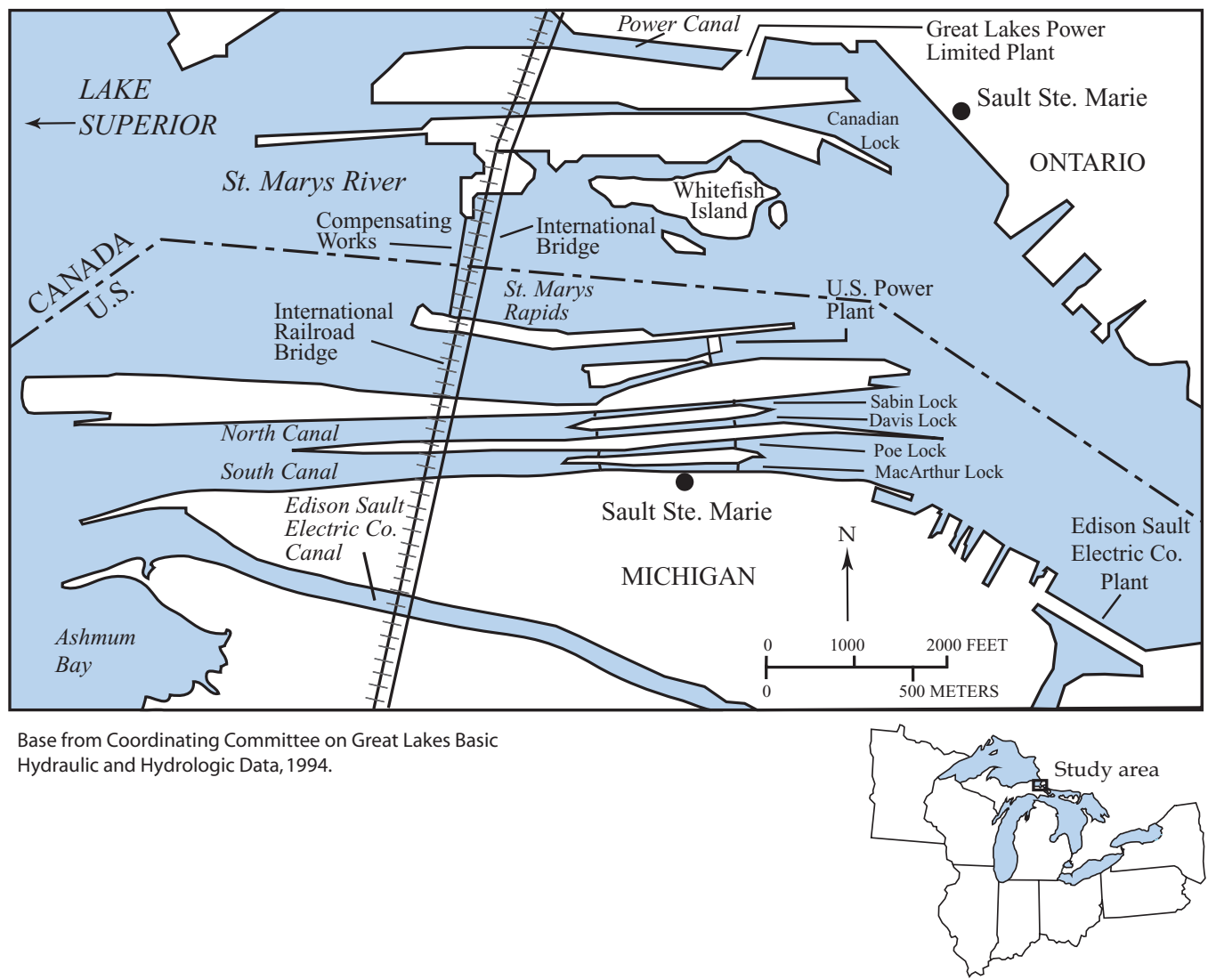

Figure 7. Soo Navigation Locks at Sault Ste. Marie, Ontario, and Michigan.

\section{Lake Erie Outflow}

Water flows north out of Lake Erie and into Lake Ontario through the Niagara River and the Welland Canal (fig. 11). The Niagara River is about $36 \mathrm{mi}$ long and drops $326 \mathrm{ft}$ between Lakes Erie and Ontario, including the 167-ft drop at Niagara Falls (Coordinating Committee, 1976, p. 5). The Welland Canal flows roughly parallel to the Niagara River and permits shipping to bypass the Niagara River.

Several phenomena affect Lake Erie outflow. Wind set-up and seiche on Lake Erie, ice floes and jams, frazil ice (also frequently called anchor ice), and summertime aquatic plant growth in the Niagara River channel all affect Lake Erie outflow. Installation of the Lake Erie Ice Boom has reduced ice floes and has eliminated almost all of the once-common ice jams (International Niagara Working Committee, 2001).
There are many diversions of flow from and between the Niagara River and Welland Canal, including flows through the New York State Barge Canal and numerous hydropower related diversions. The complexity of this system is shown in figures 11, 12, and 13. Since records have been kept, monthly Lake Erie outflow has averaged approximately 210,000 $\mathrm{ft}^{3} / \mathrm{s}$. Maximum monthly average flows have been as high as $268,000 \mathrm{ft}^{3} / \mathrm{s}$ and as low as $118,000 \mathrm{ft}^{3} / \mathrm{s}$ (according to data reported by Croley and others, 2001).

\section{Lake Ontario Outflow}

The St. Lawrence River flows northeast out of Lake Ontario at Kingston, Ontario. Several control structures that make up the St. Lawrence-Franklin D. Roosevelt Power Project (fig. 14) have been constructed for safety, to regulate Lake Ontario water levels and outflow, and to permit shipping. 


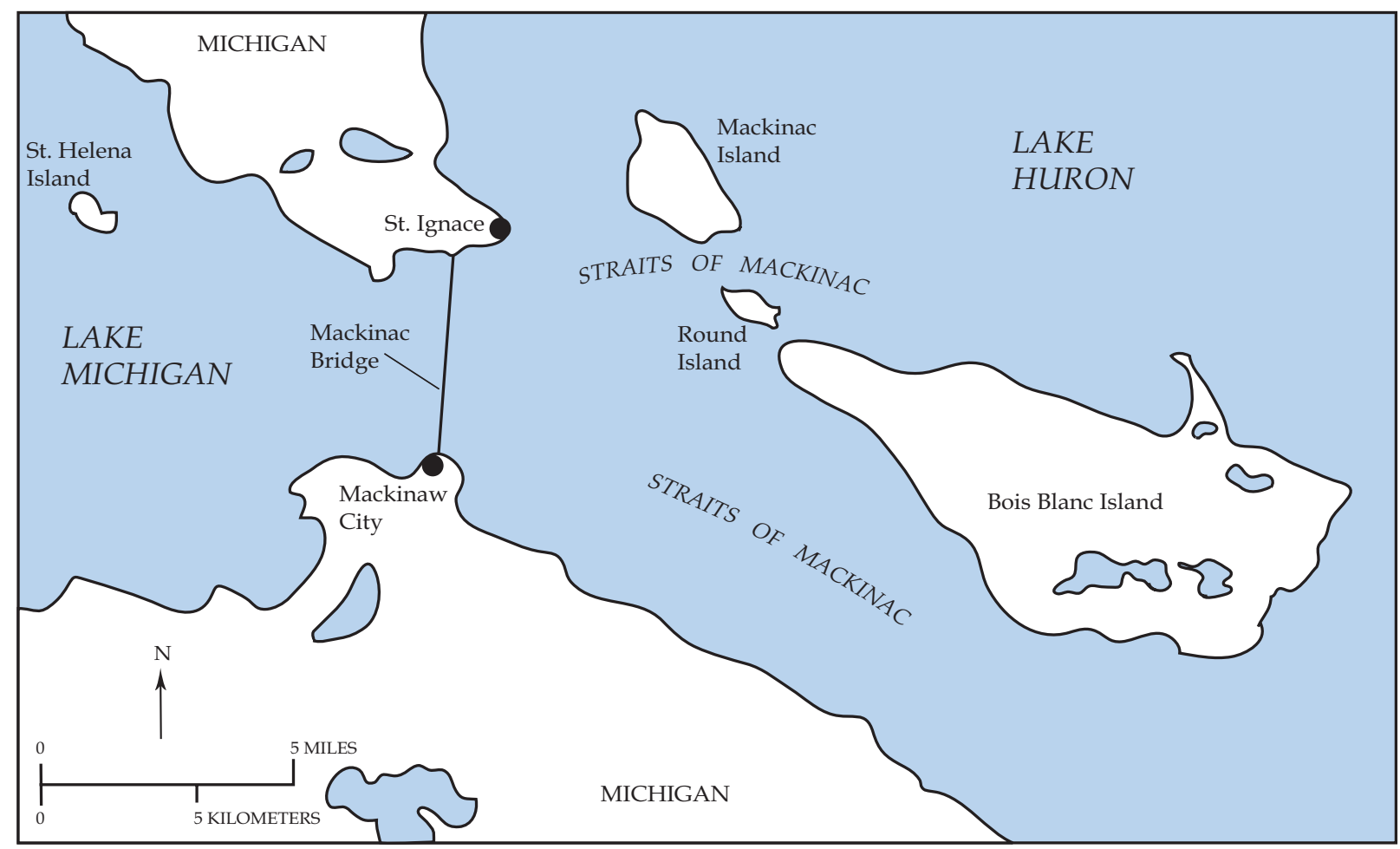

Base from U.S. Geological Survey 1:24,000 quadrangles.

Figure 8. Straits of Mackinac, Michigan.

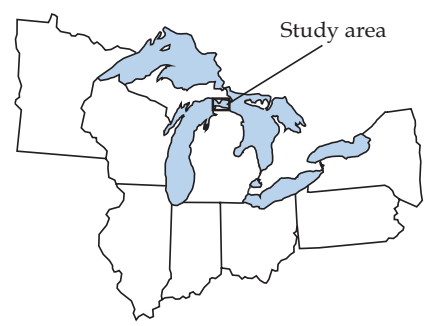

\section{Evaporation}

Lake Ontario outflow is measured at the Moses-Saunders power dam, near the cities of Cornwall, Ontario, and Massena, New York. This dam is 112 mi downstream from where the St. Lawrence River leaves Lake Ontario at Kingston.

The Moses-Saunders power dam is generally considered the downstream terminus of the Great Lakes and Lake Ontario Basins. Since records have been kept, monthly Lake Ontario outflows have averaged 246,000 ft $3 / \mathrm{s}$. Average monthly flows have been as high as 357,000 ft's and as low as $154,000 \mathrm{ft}^{3} / \mathrm{s}$ (based on data reported by Croley and others, 2001).
The Great Lakes are the single largest source of fresh surface water on Earth and cover a vast area. Large amounts of water evaporate from this surface: consider that water lost to evaporation exceeds the total amount of runoff into the Great Lakes (fig. 3; based on data presented by Croley and others, 2001).

Evaporation is a highly seasonal phenomenon on the Great Lakes. The general pattern consists of very high evaporation rates in fall and winter and very low evaporation rates in spring and summer (fig. 15). During winter, cold air moves over the relatively warm lakes. As the air warms, it is able 


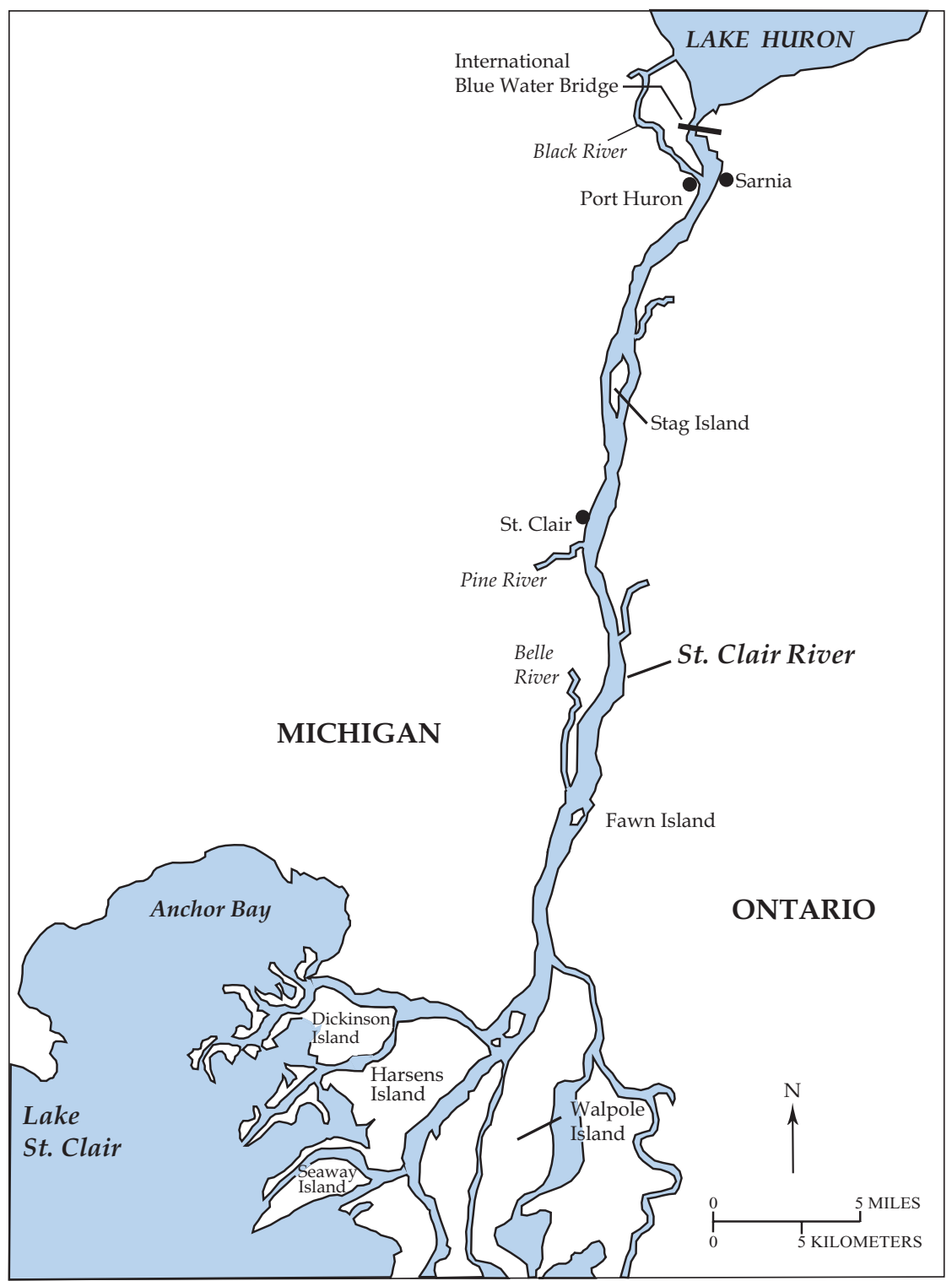

Base from Coordinating Committee on Great Lakes Basic Hydraulic and Hydrologic Data, 1994.

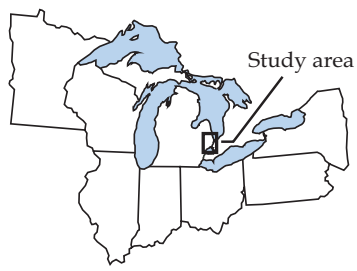

Figure 9. St. Clair River near St. Clair, Michigan. 


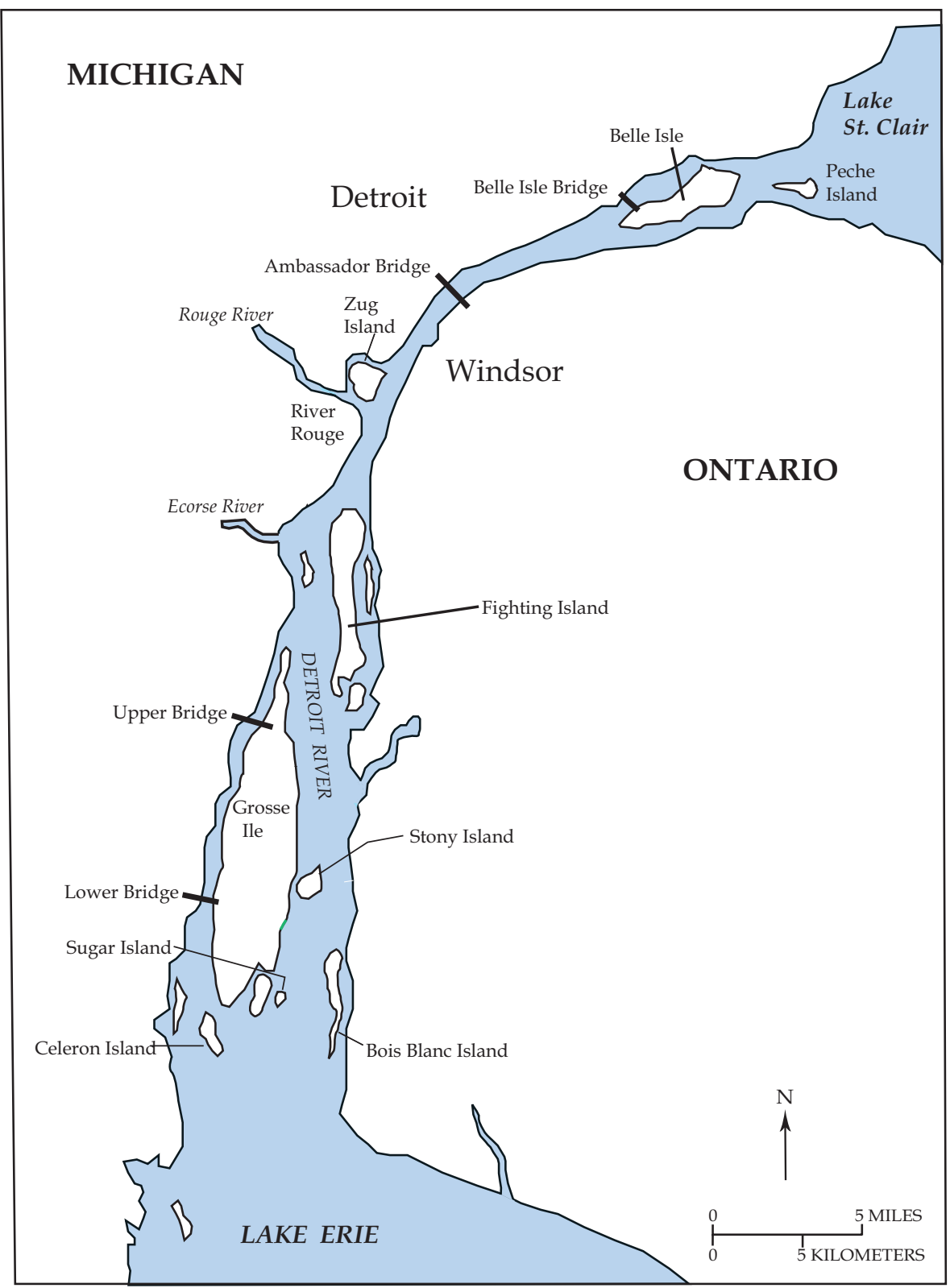

Base from Coordinating Committee on Great Lakes Basic Hydraulic and Hydrologic Data, 1994.

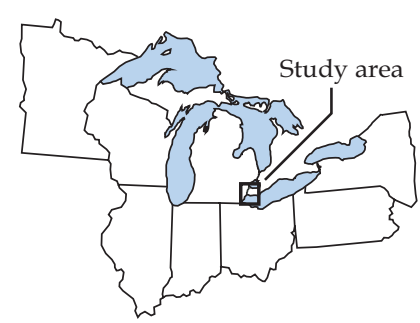

Figure 10. Detroit River near Detroit, Michigan. 


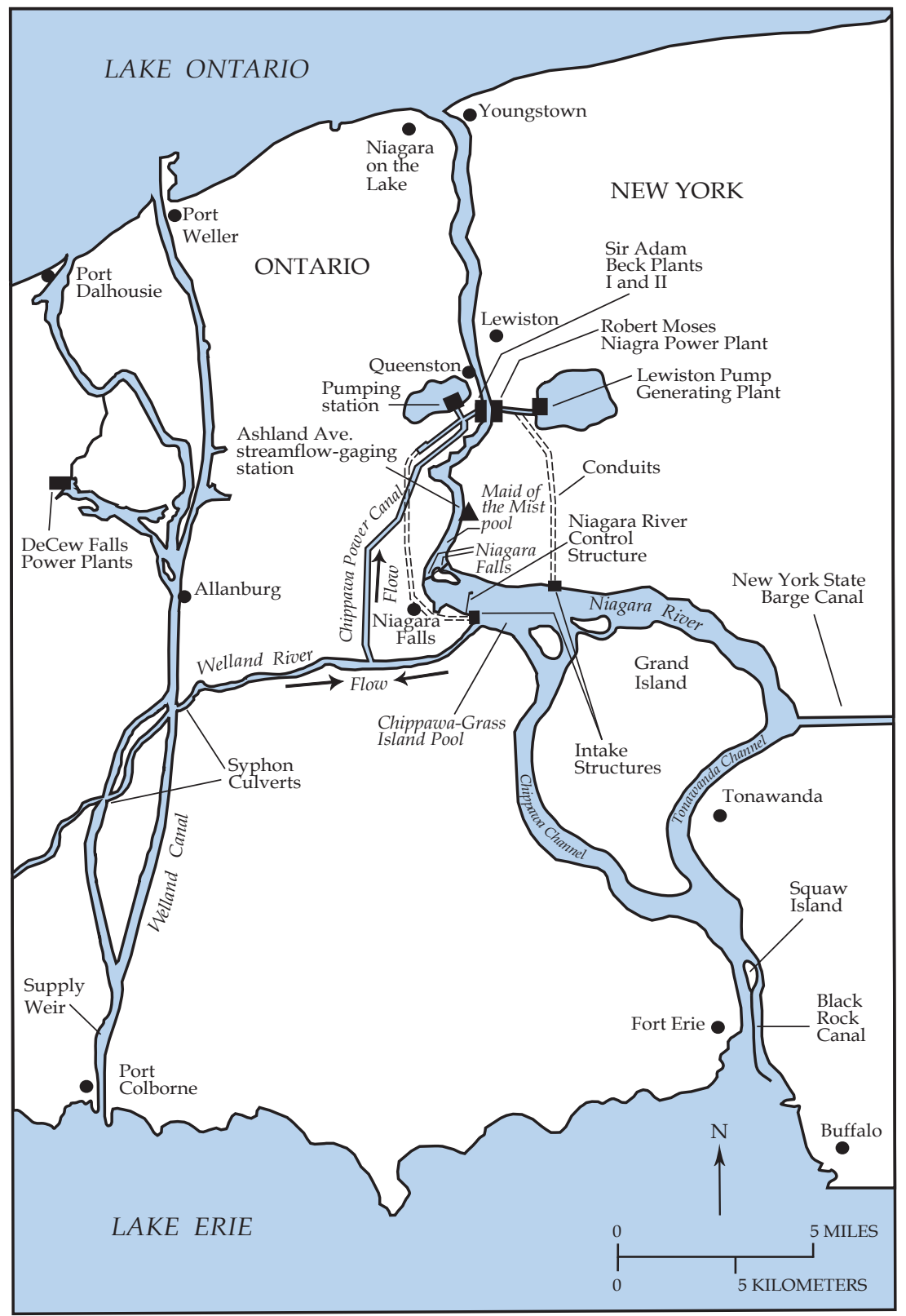

Base from the International Joint Commission, 1985.

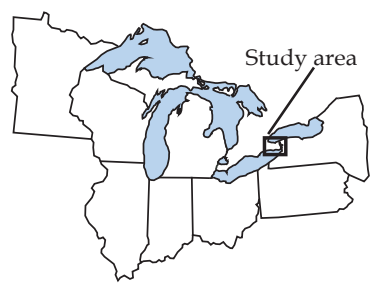

Figure 11. Welland Canal diversion, Ontario. 


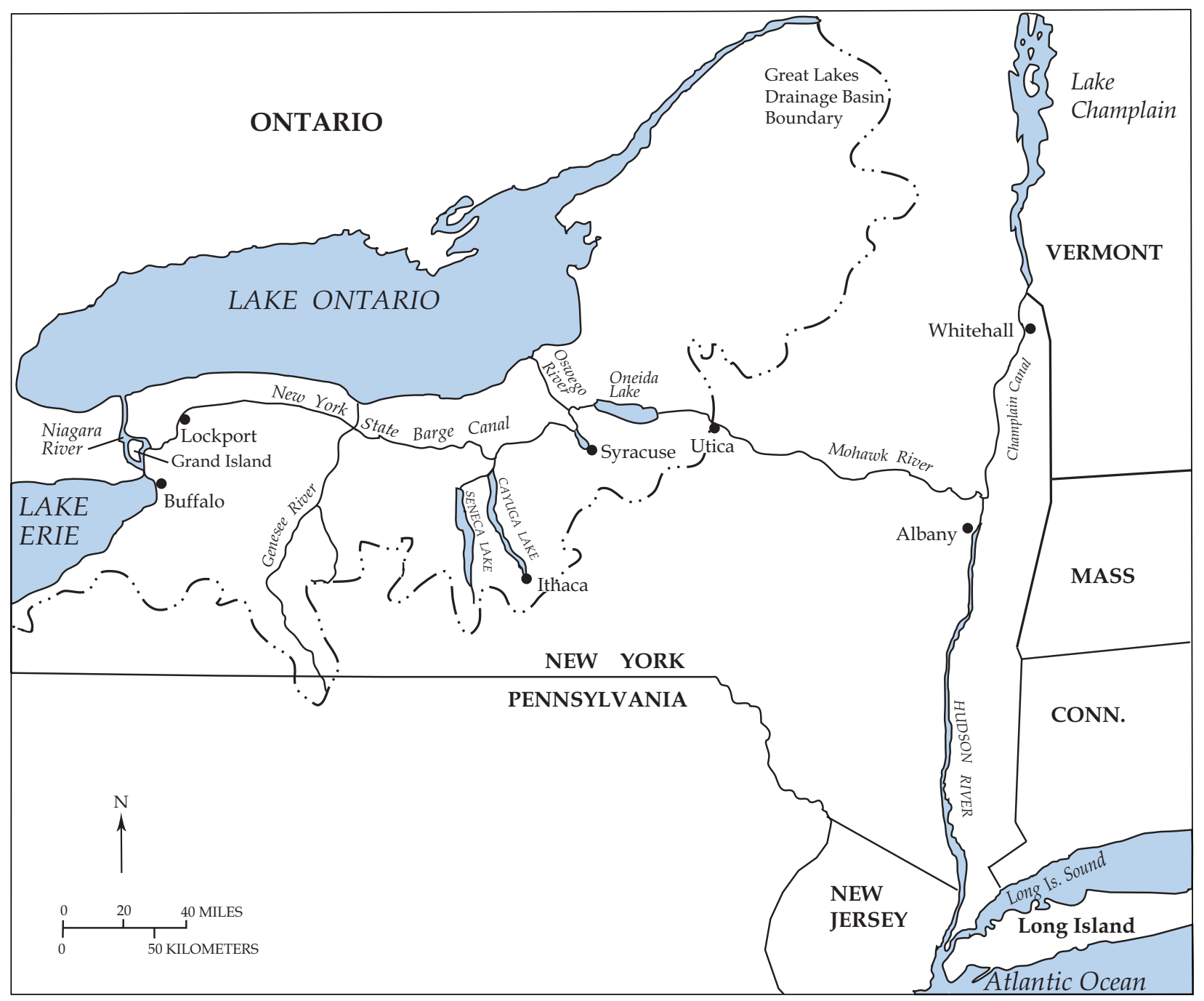

Base from the International Joint Commission, 1985.

\section{EXPLANATION}

- ..- GREAT LAKES DRAINAGE BOUNDARY

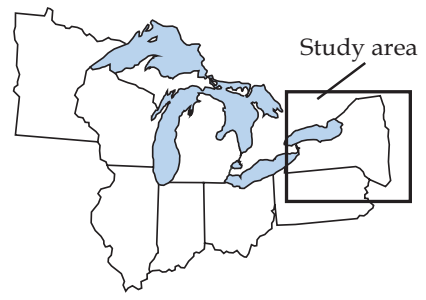

Figure 12. The New York State Barge Canal diversion near Buffalo, New York. 


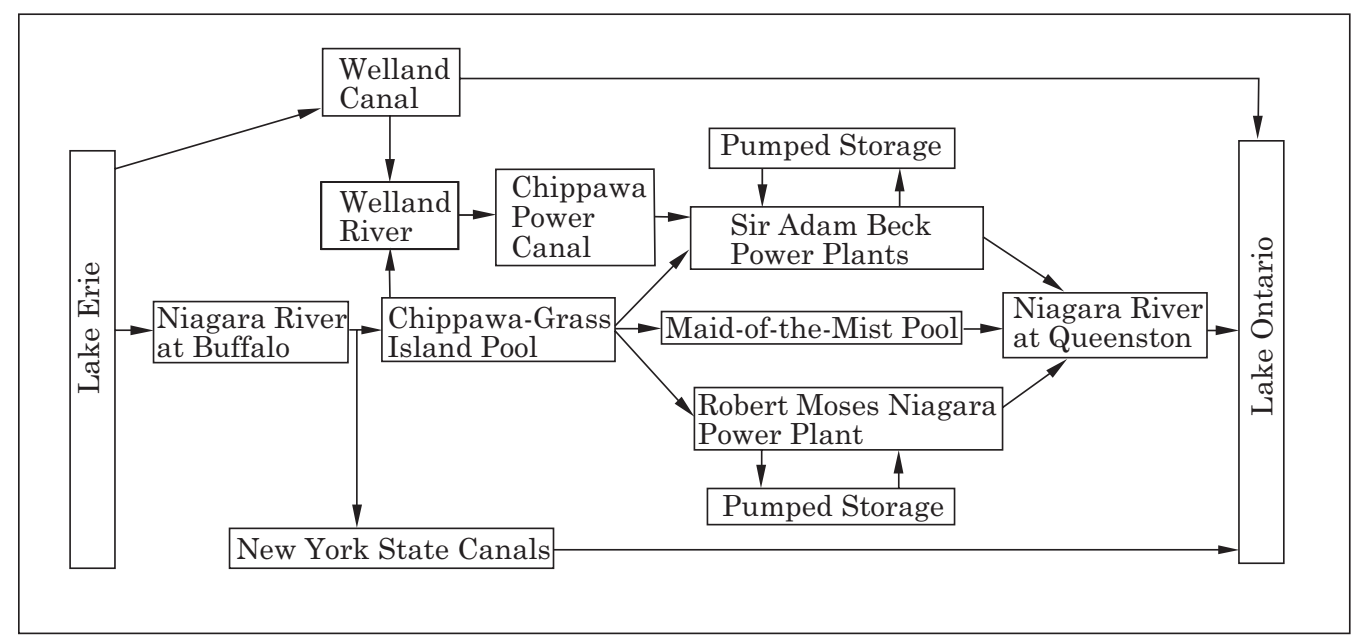

Figure 13. Flow pattern from Lake Erie to Lake Ontario. (Modified from Coordinating Committee on Great Lakes Basic Hydraulic and Hydrologic Data, 1994.)

to absorb more moisture, causing evaporation to increase. Evaporation rates lessen as ice covers parts of the Great Lakes in winter (Eichenlaub 1979, p. 141-173).

Ice formation on the Great Lakes varies greatly from lake to lake and from year to year. Lake Erie is the shallowest lake and has 90 percent ice cover in an average year. In contrast, deeper Lake Ontario has only 24 percent ice cover in an average year. Complete freezing of the Great Lakes is a rare occurrence; 1979 is the only year on record when all of the lakes froze over nearly completely (Assel and others, 1983, table 6-1).

\section{Diversions}

The first of three major diversions out of the Great Lakes (from west to east) is the Chicago diversion (fig. 16). The canal system intakes at Chicago draw water from Lake Michigan for municipal water supply, navigation, and dilution of effluent from several water reclamation plants near the city. The water is diverted into the Des Plaines and Calumet Rivers in the upper Mississippi River Basin.

Total authorized annual diversion of Lake Michigan water by the State of Illinois has varied historically, though it has been set at an annual average of $3,200 \mathrm{ft}^{3} / \mathrm{s}$ since 1967 . Actual annual flows have at times exceeded this amount, although diverted flows have been reduced below this threshold since 1994 in an effort to maintain a long-term average of 3,200 ft $3 / \mathrm{s}$ or less (table 1). The quantity of water diverted at Chicago is relatively small when considered in the context of the Great
Lakes water balance: it is approximately equal to 4 percent of the amount of water that evaporates from Lakes MichiganHuron, less than 2 percent of the outflow from Lakes Michigan-Huron, and slightly more than 1 percent of Lake Ontario outflow (based on data reported by Croley and others, 2001). However, the water withdrawn from the Chicago diversion has lowered the water level of Lakes Michigan-Huron by 2.5 in. and of Lake Erie by 1.7 in. (International Joint Commission, 1985 , p. 15).

Two other diversions, the New York State Barge Canal (NYSBC, fig. 12), and the Welland Canal (fig. 11), divert major amounts of water into Lake Ontario from Lake Erie and the Niagara River, respectively. One important difference between these two canals and the Chicago diversion is that the Chicago diversion is an interbasin diversion, transferring water from the Great Lakes Basin to a non-Great Lakes Basin. Water is diverted from the Niagara River to supply the NYSBC. All the water passing through the NYSBC flows to Lake Ontario, except for small, non-quantifiable amounts lost to evaporation and seepage. The long-term Great Lakes water balance is not affected by the NYSBC, nor does the NYSBC have any hydraulic effect on any Great Lake.

The Welland Canal is used for hydropower production and permits shipping to bypass the Niagara River and Falls and move between Lakes Erie and Ontario. Water enters the canal from Lake Erie at Port Colborne, Ontario, about $15 \mathrm{mi}$ west of the head of the Niagara River, and flows north. Most of the water is diverted from the canal for power production at the OPG DeCew plants in St. Catharines, Ontario, and then enters Lake Ontario at Port Dalhousie, Ontario, about $9 \mathrm{mi}$ 


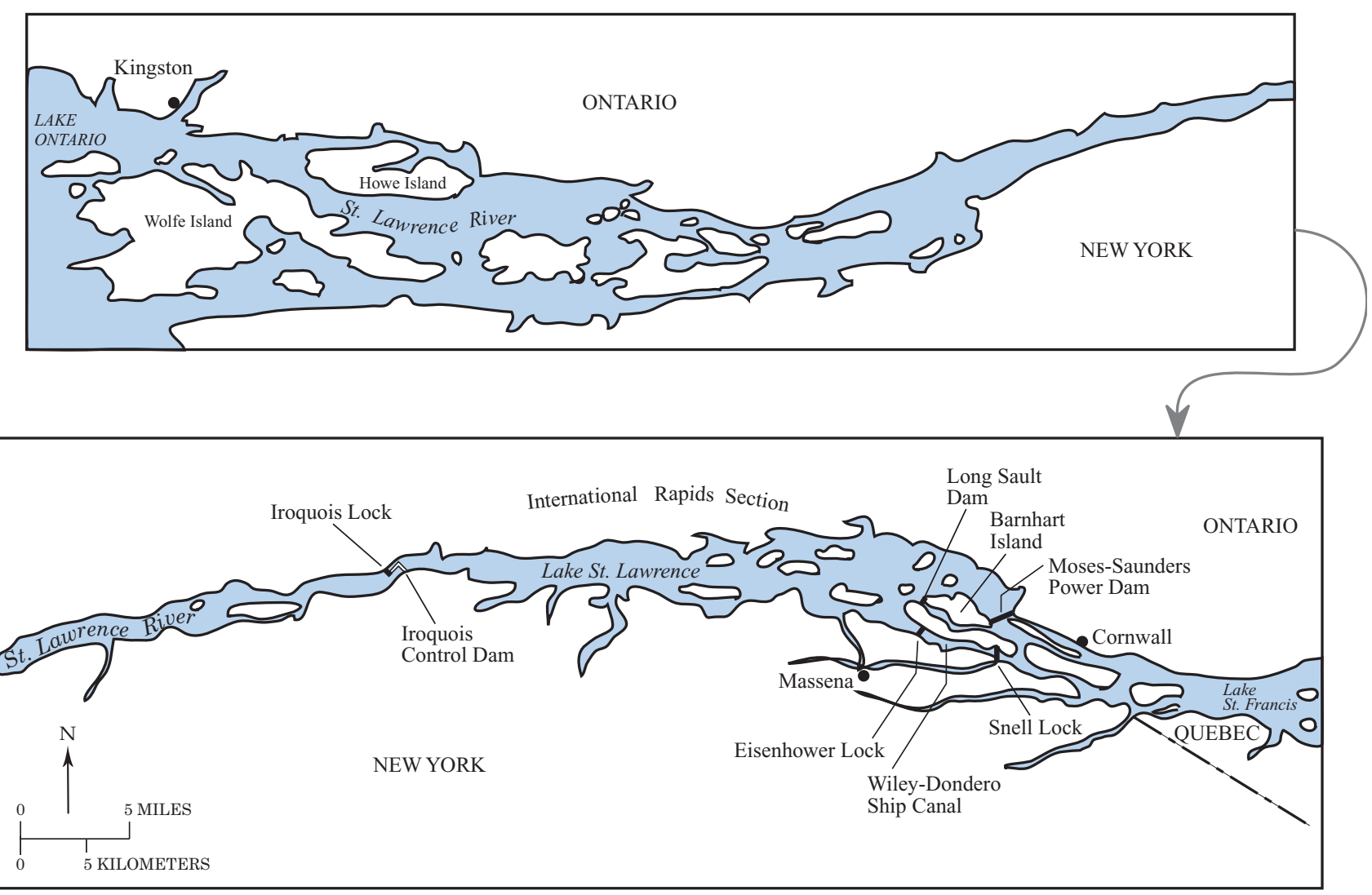

Base from Coordinating Committee on Great Lakes Basic Hydraulic and Hydrologic Data, 1994.

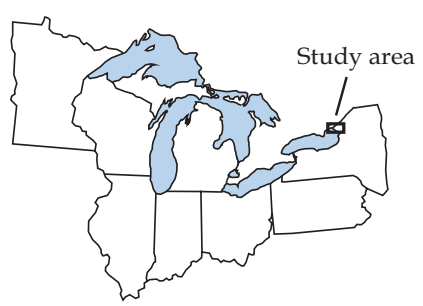

Figure 14. St. Lawrence River downstream from Kingston, Ontario, to Lake St. Francis.

west of the mouth of the Niagara River (fig. 11). The Welland Canal discharges into Lake Ontario at Port Weller, Ontario, a location about $7 \mathrm{mi}$ west of the mouth of the Niagara River. Some of the water entering the Welland Canal is diverted into the Welland River at Welland, Ontario, where it flows eastward until it joins westbound Welland River flow. At this point, combined flow is routed into a canal and flows north to Sir Adam Beck powerplants I and II and is discharged into the Niagara River at Queenston, Ontario. Water entering the Welland Canal during 1973 through 2001 has averaged $8,400 \mathrm{ft}^{3} / \mathrm{s}$, more than 2.5 times the flow through the Chicago diversion. This increase in Lake Erie outflow capacity has drawn down Lake Erie by approximately 5.3 in. Because the level of Lake Erie naturally affects the level of Lakes Michigan-Huron, the Welland Canal diversion has lowered those lakes by 2.2 in. By regulation agreements, this has resulted in lowering Lake Superior by 0.7 in (International Joint Commission, 1985, p. 18). All the water passing through the Welland Canal returns to Lake Ontario, except for small, non-quantifiable amounts lost to evaporation and seepage. The Welland Canal does not affect the long-term water balance of the Great Lakes. A schematic of Lake Erie outflow is shown in figure 13. Other diversions of water out of the Great Lakes exist (International Joint Commission, 1999, p. 10), but are relatively small and not considered in this report. 


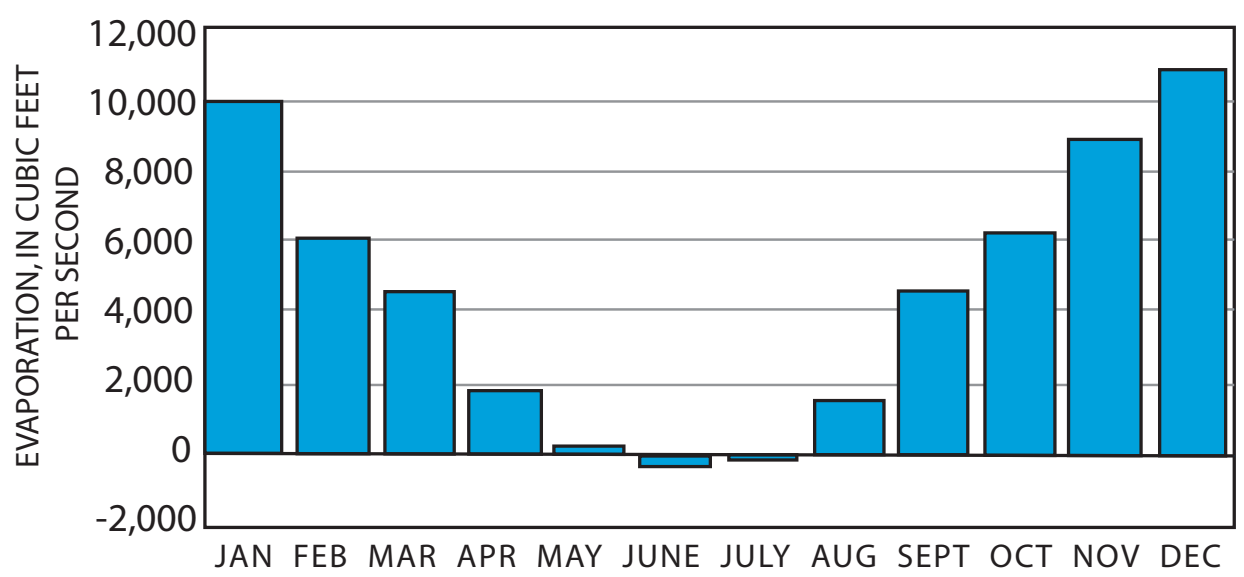

Figure 15. Monthly evaporation rates of Lake Superior. (From Great Lakes Commission, 2003.)

\section{Consumptive Use}

Water withdrawn or withheld from the Great Lakes Basin and assumed to be lost or otherwise not returned to the Great Lakes Basin because of evapotranspiration, incorporation into products, or other processes is termed consumptive use. Consumptive use is a very small component of the water balance and is not considered in this report. A comprehensive discussion of consumptive use is included in chapter 3 of the GLC report, "Toward a Water Resources Management Decision Support System for the Great Lakes-St. Lawrence River Basin” (2003).

\section{Change in Storage}

Once inflow and outflow of each lake have been assessed, calculation of change in storage of the Great Lakes renders a complete water balance. Change-in-storage calculations are based on a net change in lake stage and the surface area of each Great Lake. As stated in the introduction, the Great Lakes have a very large capacity to store water. A relatively small change in lake stage can represent a vast amount of water that is being held by or released from the lake.

The effect of changes in lake levels on surface area of the Great Lakes is assumed to be negligible. As water levels drop, the lakes cover less area. However, the large surface area of the Great Lakes mitigates any effect changing water levels have on total surface area. A change in lake level resulting in an average loss or gain of approximately $500 \mathrm{ft}$ of shorefront would be needed to change the area of the lakes by 1 percent. For this reason, change in the surface area of the Great Lakes caused by changing water levels is not considered when quantifying change in storage or any other component in the Great Lakes water balance.
The magnitude of change in storage is highly variable. At times, levels of the Great Lakes may be stable, and the change in storage term can be close to zero. At other times, however, the change in storage term can be positive or negative and greater than any other component of the water balance. Between 1900 and 2000, Lake Superior monthly net change in storage ranged from $-184,000 \mathrm{ft}^{3} / \mathrm{s}$ in October 1952 to $+303,100 \mathrm{ft}^{3} / \mathrm{s}$ in May 1950 (based on data reported in Croley and others, 2001).

\section{Methods for Quantifying Components and Potential Uncertainties}

The Great Lakes water balance is a compilation of literally thousands of daily measurements of many hydrologic and atmospheric parameters. Additionally, numerous approaches to assess each component are available, and each approach introduces a different amount of potential uncertainty to the water balance. Types of uncertainties discussed in this section include measurement uncertainties, model uncertainties, and monitoring gaps.

Currently (2004), the uncertainty of most water-balance components is impossible to assess. For example, the overall uncertainty in runoff estimates cannot be calculated. In gaged areas, both the magnitude of streamflow and the uncertainties in estimates for individual stream gages constantly fluctuate in response to ever-changing hydrologic conditions. These fluctuations are also unique to each gage. In ungaged areas, little is known about the reliability of current estimates. 


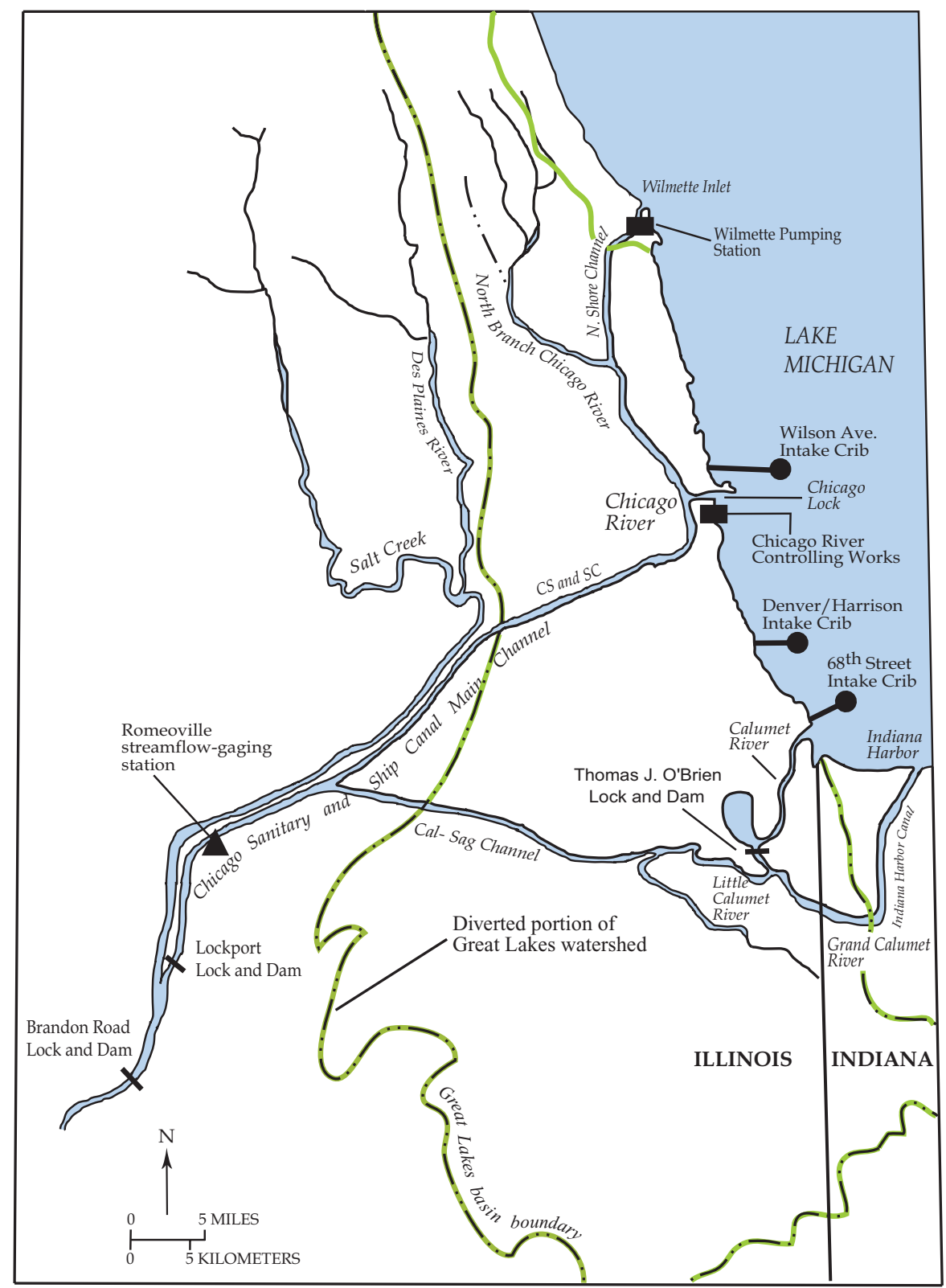

Base from the International Joint Commission, 1985.

\section{EXPLANATION}

- -.- GREAT LAKES BASIN BOUNDARY

DIVERTED PORTION OF GREAT LAKES WATERSHED

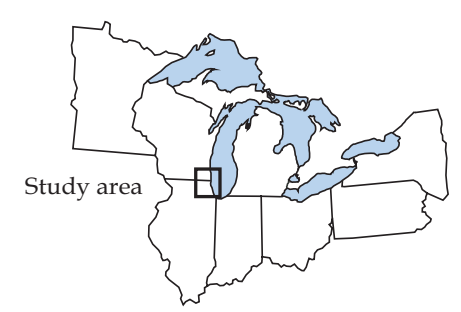

Figure 16. Chicago diversion near Chicago, Illinois. 
Table 1. State of Illinois annual diversion flows, certified by the U.S. Army Corps of Engineers, Chicago District $\left[\mathrm{ft}^{3} / \mathrm{s}\right.$, cubic feet per second].

\begin{tabular}{cccc}
\hline $\begin{array}{c}\text { Accounting } \\
\text { year }\end{array}$ & $\begin{array}{c}\text { Certified Flow } \\
\left(\mathrm{ft}^{3} / \mathrm{s}\right)\end{array}$ & $\begin{array}{c}\text { Accounting } \\
\text { year }\end{array}$ & $\begin{array}{c}\text { Certified Flow } \\
\left(\mathrm{ft}^{3} / \mathrm{s}\right)\end{array}$ \\
\hline 1981 & 3,106 & 1991 & 3,555 \\
1982 & 3,087 & 1992 & 3,409 \\
1983 & 3,613 & 1993 & 3,841 \\
1984 & 3,432 & 1994 & 3,064 \\
1985 & 3,472 & 1995 & 3,197 \\
1986 & 3,751 & 1996 & 3,108 \\
1987 & 3,774 & 1997 & 3,114 \\
1988 & 3,376 & 1998 & 3,060 \\
1989 & 3,378 & 1999 & 2,909 \\
1990 & 3,531 & & \\
\hline
\end{tabular}

This underscores the difficulty of this study. Runoff is a tangible component of the water balance. Other parts of the water balance, such as evaporation, are diffuse and invisible. It is intuitive that runoff should be the easiest component to understand, yet it is not even clear how accurately it is measured.

In such cases where estimating a single uncertainty for a water-balance component is impossible, a range of reasonable monthly estimate uncertainty is stated. This range is based on the professional judgment of members of the Status Assessment of Water Resources Technical Subcommittee 2, assembled in support of the GLC report "Toward a water resources management decision support system for the Great Lakes-St. Lawrence River Basin" (2003). The term "reasonable" is used to signify a 90percent confidence that the true magnitude of the quantity being estimated lies within a given percentage of the estimated value.

\section{Inflows}

Uncertainty of estimates of inflow to the Great Lakes depends on the methods used to quantify each component and on the nature and magnitude of each inflow component. Only two diversions of water into the Great Lakes Basin will be considered in this section-the Long Lac and Ogoki diversions. The methods used for quantifying connecting-channel flow and its potential uncertainty will be described in the outflows section.

\section{Over-Lake Precipitation}

Over-lake precipitation is a very large component of the Great Lakes water balance, larger than either runoff or evaporation. Yet, opportunities to verify current estimates of over-lake precipitation with direct observations of over-lake precipitation have been few. Understanding the uncertainty of over-lake precipitation estimates is perhaps the single largest obstacle to determining the uncertainty of the Great Lakes water balance. Improving over-lake precipitation estimates also may represent the single largest opportunity to improve estimates of the overall water balance.

Uncertainty of over-lake precipitation estimates has two main sources, instrumentation uncertainty and inaccuracies in modeling. Precipitation measurement remains an inexact science. Precipitation gages are not perfect. Gages tend to underestimate precipitation largely because of wind-induced turbulence near the opening of the gage and adhesion of moisture to the internal walls of the gage. Bias can range from 5 percent to 40 percent for monthly precipitation estimates (Groisman and Legates, 1994). Generally, accuracy is in inverse proportion to temperature and wind velocities; rain is more accurately gaged than snowfall, and wind exacerbates gaging problems. Legates and DeLiberty (1993) estimate that biases in monthly gagemeasured precipitation in the U.S. part of the Great Lakes Basin vary from 10 to 14 percent; the authors also point out that the uncertainty in gaging is not constant from year to year. Overall, uncertainty in gaged precipitation is highly dependent on wind conditions and amount of snowfall recorded in each specific year.

Modeling the amount and timing of precipitation over a system as highly variable as Great Lakes is no easy task. Currently (2004), estimates of over-lake precipitation are based on numerous nearshore precipitation measurements and the Thiessen weighting method (Croley and Hartmann, 1985). In effect, the precipitation falling over the lakes is assumed to be equal to the amount of precipitation recorded at the nearest land-based gaging station. The weather stations used to define the Thiessen polygons in current precipitation estimates are all on land, near the shoreline of each lake (fig. 17; Croley, 1998, p. 49). Stations on peninsulas or on islands should represent over-lake conditions better than stations on the mainland, but these are few in comparison to the number of mainland stations. Because of the lack of direct observations of over-lake precipitation, it is not possible to accurately assess the magnitude of uncertainty in current studies that report over-lake precipitation.

The lack of direct measurements of over-lake precipitation is potentially very significant. Weather in the Great Lakes Basin is highly variable, and much of the variability of precipitation takes place where the lakes meet the land. An excellent example of this variability is lake-effect snow. In fall and winter, cold air masses frequently move across the Great Lakes from the north and west. As these air masses move over a Great Lake, the relatively warm lake heats the air, permitting more evaporation from the lake surface. When the air mass moves inland, the cooler land surface cools the air mass and causes the additional moisture to precipitate as lake-effect snow. The net effect is for precipitation to be dramatically different over the lakes than it is on the land areas nearby. In this example, conditions on the upwind side of a Great Lake would be similar to over-lake conditions (dry). However, if a land-based gage on the downwind side of the lake were to catch lake-effect snow, the result could be substantial overestimation of over-lake precipitation. Another example of this kind of variability is caused by convective thunderstorms. In summer, the relatively cool lakes tend not 


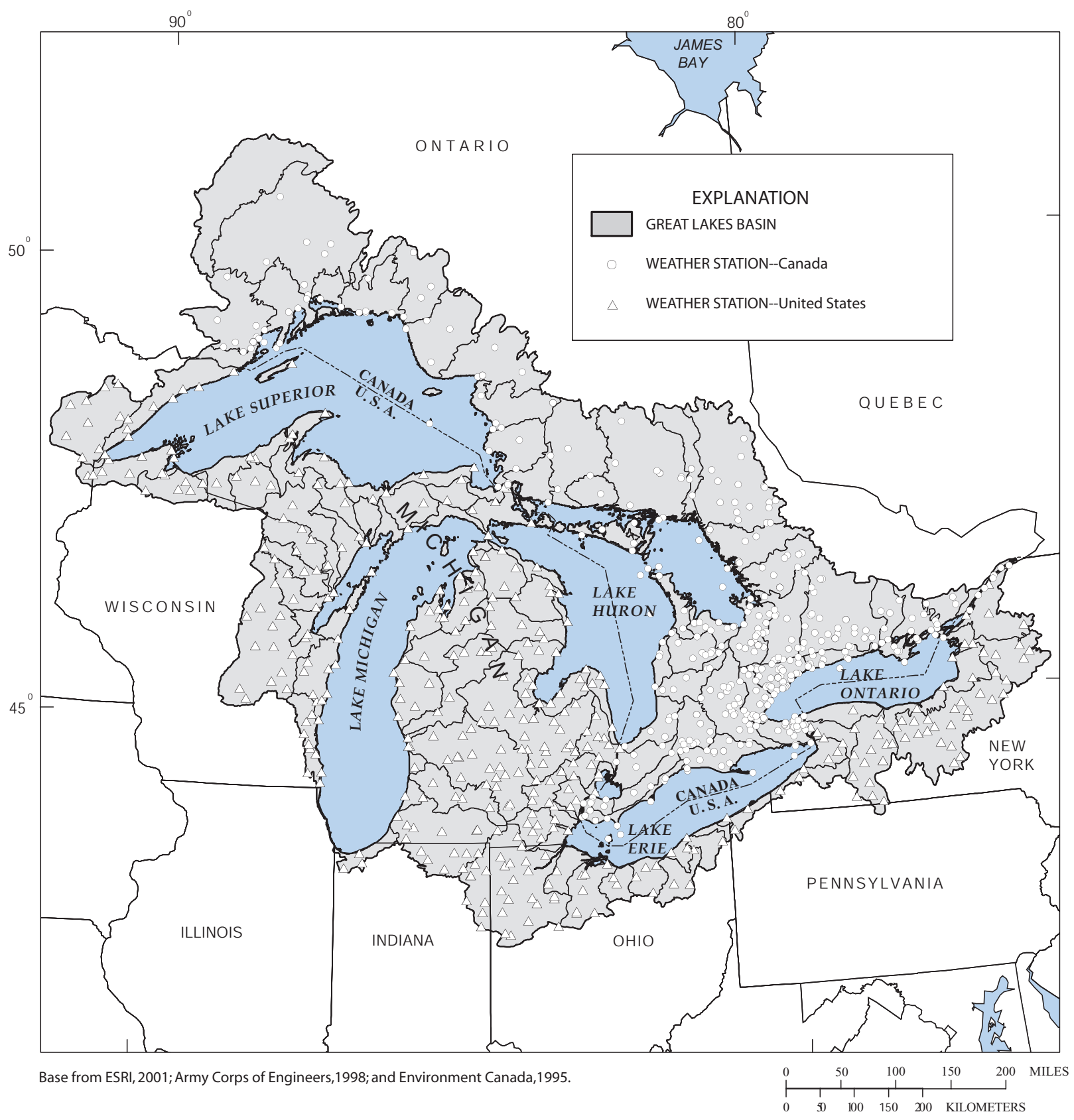

Figure 17. Weather stations in the Great Lakes Basin. (Canadian data from Ontario Climate Center, 2002; U.S. data from National Climatic Data Center, 2002.) 
to generate or sustain convective thunderstorms; however, these storms can form and persist over land. If a land-based precipitation gage captures rainfall from convective storms that dissipate a short distance offshore, then the result would be overestimation of over-lake precipitation. A thorough discussion of these and other meteorological phenomena are given in Eichenlaub (1979).

Two potential tools for assessing precipitation over the Great Lakes are Doppler radar and weather buoys. Doppler radar, which has emerged in recent years as a useful tool in weather monitoring and forecasting, permits direct estimation of precipitation over the surface of the lake. The U.S. National Weather Service (NWS) currently maintains a network of Doppler radar stations in the Great Lakes Basin that could be used to estimate over-lake precipitation. Environment Canada (EC) is currently installing Doppler radar stations or retrofitting existing radar stations with a Doppler capacity. The entire over-lake area of the Great Lakes could be monitored by means of these networks. Radar-based precipitation estimates would not be without problems. Like traditional gage measurements, warm-weather precipitation is more reliably measured than cold-weather precipitation. Currently (2004), no datasets of Doppler-based Great Lakes precipitation are readily available. Despite these problems, use of Doppler radar technology to estimate over-lake precipitation could help researchers assess the variability in precipitation over the lakes.

The U.S. National Oceanic and Atmospheric Administration (NOAA) and EC operate a network of buoys throughout the Great Lakes that could potentially be outfitted with equipment to monitor precipitation. The accuracy of precipitation gages on buoys is affected by wave action, and therefore is likely to be highly variable. Buoy-based precipitation measurements could be worse than land-based gages, particularly in the fall and winter; but under ideal conditions, buoy-based precipitation measurements could possibly be used to help verify or corroborate current models. Because buoys are removed from the lakes each winter, year-round over-lake precipitation monitoring would not be possible with buoys.

Given the general uncertainty of monthly precipitation estimates from land-based gaging networks and possible differences in over-lake and over-land precipitation, the uncertainty is likely to be more than 15 percent and could be as high as 45 percent during some winters. Three steps would need to be taken to permit a better assessment of precipitation uncertainty. First, uncertainty and bias inherent to the binational Great Lakes gaging network would need to be quantified. Second, reliability of the Thiessen polygon approach would need to be evaluated with reference to accurate over-lake precipitation estimates. Third, possibilities of using Doppler radar and buoy-based precipitation measurements to verify the accuracy of current techniques would need to be explored.

\section{Runoff}

Runoff includes streamflow and direct overland flow to the Great Lakes. Streamflow is calculated for gaged areas and ungaged areas. Official data, published by EC and the USGS, describe streamflow in gaged basins. All active stream gages in the Great Lakes Basin are shown in figure 18. These agencies do not publish basinwide data for ungaged areas. Some researchers generate estimates of runoff in ungaged areas to calculate total runoff to the Great Lakes.

\section{Gaged Areas}

Streamflow is generally not continuously measured; instead, a stage-discharge or velocity-discharge relation is established to estimate streamflow on a continuous basis. In these methods, streamflow is measured directly at many stream stages or velocities. These data are used to develop a regression relation that mathematically relates the stage or velocity of a stream and its discharge. Continuous records of stage or velocity can be used to determine streamflow on an ongoing basis. Some degree of uncertainty exists in these stage-discharge and velocity-discharge relations. Uncertainty may result from improperly measuring streamflow or from not recording the stage or velocity of the stream accurately. The USGS and the Meteorological Survey of Canada (MSC, formerly known as the Water Survey of Canada) take measures to minimize inaccuracy in these measurements.

Specialized gaging procedures and quality-assurance procedures followed by reporting agencies attempt to prevent biases and inaccuracies in calculated stage-discharge and velocity-discharge relations. Over time, the flow characteristics of a stream-and, consequently, the stage-discharge and velocity-discharge relation-tend to change. When field measurements of stage and discharge or velocity and discharge consistently fall outside the tolerances of the measuring agency for the existing stage-discharge or velocity-discharge regression, that agency will develop a new regression relation. If short-term or seasonal factors such as vegetation growth, ice cover, or debris in the river are influencing streamflow, correction factors are applied to the stage or velocity measurements using the shifting control method (Rantz and others, 1982). Streamflow is then based on these adjusted stage measurements.

Special hydrologic conditions can affect the uncertainty of streamflow estimation. For example, floods present a special problem to estimating discharge. If a stream overflows its banks, the accuracy with which streamflow can be estimated decreases significantly. Compounding the problem is the fact that flood streamflows may be many times greater than the normal streamflow of the stream. So, the inaccuracies during a relatively short flood event (hours to weeks) may amplify the total uncertainty in longer-term runoff estimates significantly (days to years).

Records of streamflow are often temporally incomplete. When temporal data gaps occur, they must be replaced somehow by estimated streamflows. Many estimation methods exist, but all introduce additional uncertainty to the streamflow record. Once a best estimate of streamflow at gaging stations is determined, streamflow data are published by the USGS (Blumer and others, 1999, p. 8) and the MSC. 


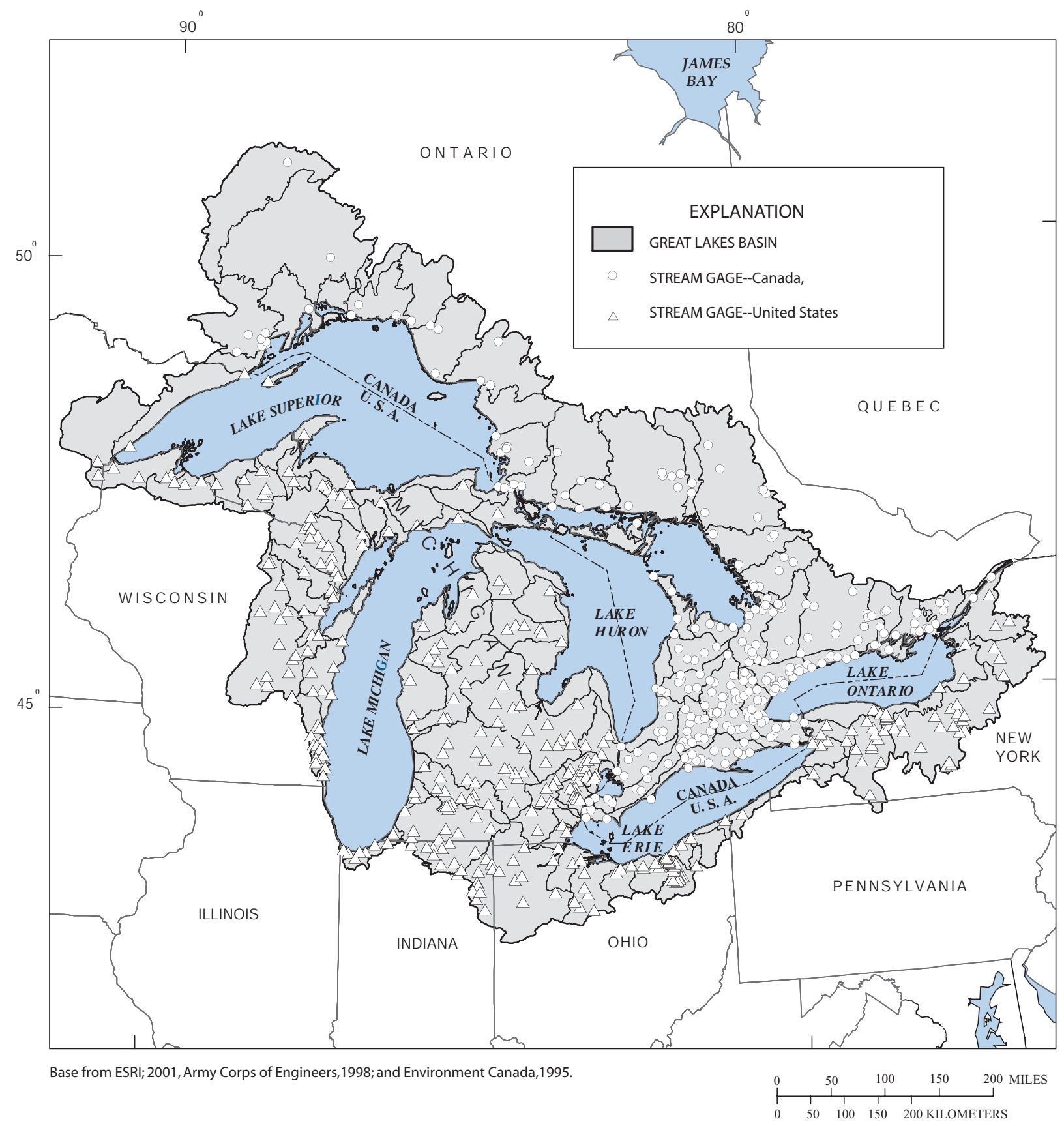

Figure 18. Stream gage locations in the Great Lakes Basin. (Canadian data from Meteorological Service of Canada, 2002.) 
Statistical statements exist to describe uncertainty in streamflow estimates at individual stream gages, but no estimates of the total uncertainty in the Great Lakes stream gaging network are available. The USGS provides a statement of accuracy of its published data for individual stream gages. The streamflow estimates are rated as "excellent," "good," or "fair." These terms signify confidence that 95 percent of the reported daily streamflows are within 5 percent, 10 percent, or 15 percent of their true values, respectively. Sometimes a "poor" rating is given, indicating that 95 percent of the reported daily streamflows are believed to be more than 15 percent from their true values (Blumer and others, 1999, p. 10). Even with these statements of uncertainty, there is considerable difficulty in calculating the total uncertainty in streamflow estimates across the entire Great Lakes Basin. Many hundreds, or thousands, of gages need to be considered, and the uncertainty associated with each gage changes over time and is frequently independent of uncertainty observed at other gages. Additionally, the magnitude of streamflow at each stream gage is not uniform, or constant, and also must be considered in estimates of total uncertainty of streamflow in gaged areas of the Great Lakes Basin.

\section{Ungaged Areas}

Records of streamflow in the Great Lakes Basin are spatially incomplete for two reasons. First, gaging stations are usually several miles inland, rather than at stream mouths, leaving spatial gaps in data to describe streamflow in areas near the lakes. The inland locations of stream gages are due mainly to fluctuating water levels in the Great Lakes, which adversely affect the stage-discharge and velocity-discharge relation if stream gages are close to the mouth of the stream. Wind set-up and seiche exacerbate this problem. Factors dictating proper placement of stream gages are outlined more thoroughly in Rantz and others (1982, p. 5-8). Second, not every tributary to the Great Lakes is gaged. Neither the USGS nor the MSC reports values for runoff in ungaged areas. Rather, ungaged runoff is calculated in individual studies (for example, Croley and others, 2001; Quinn and Kelly, 1983). Table 2 gives the percentages of each Great Lake Basin that is gaged (modified from Lee, 1992, table 2.0).

Table 2. Percentage of Great Lakes Basin area that is ungaged, 1992 [\%, percent].

\begin{tabular}{cccccc}
\hline $\begin{array}{c}\text { Lake } \\
\text { Superior }\end{array}$ & $\begin{array}{c}\text { Lake } \\
\text { Michigan }\end{array}$ & $\begin{array}{c}\text { Lake } \\
\text { Huron }\end{array}$ & $\begin{array}{c}\text { Lake St. } \\
\text { Clair }\end{array}$ & $\begin{array}{c}\text { Lake } \\
\text { Erie }\end{array}$ & $\begin{array}{c}\text { Lake } \\
\text { Ontario }\end{array}$ \\
\hline $34 \%$ & $24 \%$ & $43 \%$ & $50 \%$ & $22 \%$ & $25 \%$ \\
\hline
\end{tabular}

Runoff from ungaged areas, including direct overland flow to the Great Lakes, is usually estimated by means of the runoff-to-area ratio observed in other parts of the basin. In individual basins that are partially gaged, a multiplier is commonly applied to streamflows at a particular gage within the basin to compensate for any difference in runoff between the gaging station and the stream mouth (Lee, 1992). In completely ungaged basins, the area-to-runoff ratio for gaged areas of nearby basins is used. Currently, no standard approach is officially recognized by either MSC or USGS for estimating streamflow in ungaged areas.

\section{Uncertainty In Total-Runoff Calculations}

Estimating the uncertainty in total-runoff calculations is currently difficult or impossible; however, steps could be taken to permit an estimate of this uncertainty. First would be to develop a statistical statement of the total uncertainty of streamflow estimates for all stream gages in a given Great Lake Basin. Due to the highly variable nature of streamflow estimation uncertainty over space and time, this would need to be calculated annually, if not monthly. Second would be to thoroughly examine the reliability of current methods used to estimate runoff in ungaged areas and develop a statement of uncertainty for these estimates. Lacking these kinds of information and procedures, it is currently possible to state only a reasonable range of uncertainty in current monthly runoff estimates, which is likely to be 15 percent to 35 percent.

\section{Ground-Water Discharge}

Most water-balance studies of the Great Lakes ignore ground-water discharge to the Great Lakes or treat it as part of the residual in calculations. Though many studies have attempted to estimate direct ground-water discharge, to date (2004) no large-scale attempt to actually measure groundwater seepage throughout the Great Lakes has been done. A major reason for not studying ground-water discharge is the massive effort required to actually measure seepage along the estimated 6,820 mi of mainland Great Lake and connectingchannel shoreline (Coordinating Committee, 1977). Moreover, preliminary estimates show that ground-water inputs to the Great Lakes are not likely to be a large component of the water balance.

According to Grannemann and Weaver (1999), past estimates of total ground-water inputs to Lake Michigan range from about $800 \mathrm{ft}^{3} / \mathrm{s}$ to about $6,700 \mathrm{ft}^{3} / \mathrm{s}$. On the basis of all available data and information, these researchers estimated total direct seepage into Lake Michigan to be $2,700 \mathrm{ft}^{3} / \mathrm{s}$, approximately equivalent to $2 \mathrm{ft}^{3} / \mathrm{s}$ per mile of shoreline. Grannemann and Weaver also advised that data are insufficient for estimates of ground-water seepage to the other Great Lakes, although estimated seepage rates from other studies are much smaller than those for Lake Michigan. Direct net ground-water seepage into the other Great Lakes could likely range from $0.5 \mathrm{ft}^{3} / \mathrm{s}$ to $2.0 \mathrm{ft}^{3} / \mathrm{s}$ per mile of shoreline. This amount is much smaller than that for other water-balance components, such as evaporation and direct precipitation, but 
it would be approximately the same magnitude of the Chicago diversion for each Great Lake. Ground-water inputs to the Great Lakes water balance remain an unmonitored component in the water balance.

\section{Diversions}

The flow through the Long Lac diversion is calculated as it passes through Long Lake Control Dam. This dam is a two-sluiceway structure with stop locks. Accounting of these flows is well established, is based on a stable rating curve, and is assumed to be very accurate. Water diverted from the Ogoki River flows through the Summit Control Dam. Flows through the Summit Dam are calculated on the basis of stage measurements made immediately downstream from the structure. The stream channel is stable in this section of the stream and has not changed much since the dam was built in the 1940s. Data for flows through Summit Control Dam are considered to be very accurate.

Uncertainty in diversion flows results from evaporative loss and the time lag as diverted water is in transit to Lake Superior. Data for diversion flows are generated at the point of diversion, and are representative of water diverted into the Lake Superior Basin but not necessarily the amount of water actually diverted into Lake Superior. Some quantity of the diverted water must evaporate between the points of diversion and Lake Superior, but this amount is unknown and could be negligible.

Possibly of greater significance is the use of same-month diversion data to represent the amount of water diverted into Lake Superior. Flow through the Long Lac and Ogoki diversions varies seasonally, with average June diversion flows being approximately 2.2 and 3.2 times greater than April diversion flows, respectively (according to data presented in Croley and others, 2001). There is considerable lag time from when diverted flows are measured and when they actually reach Lake Superior. In this time the component of streamflow attributable to the diversion will likely be moderated in relation to the timing of diversion flows at the point of diversion. Using same-month diversion data from the points of diversion may not properly represent the timing of water diversion to Lake Superior from the Long Lac and Ogoki diversions. Ogoki-diversion flows have an especially long journey to Lake Superior. The water diverted from the Ogoki River is channeled into the Little Jackfish River, which flows through Lake Nipigon. Lake Nipigon is a particularly large lake, covering more than 1,741 $\mathrm{mi}^{2}$ (Environment Canada, 2003), with a maximum depth of greater than $400 \mathrm{ft}$. After leaving Lake Nipigon, water flows to Lake Superior. The total travel time is likely a matter of years.

Understanding of the Long Lac and Ogoki diversions is currently insufficient to permit an exact estimation of uncertainty. The largest issue to resolve is the effect of using same-month, point-of-diversion data to represent the amount of water diverted into Lake Superior. Additionally, any evaporative loss of diversion water not accounted for by the current accounting system will add to the uncertainty in diversion flow data. A reasonable range of uncertainty in monthly Long Lac and Ogoki diversion flows is $10-30$ percent, without consideration of time-lag uncertainty.

\section{Outflows}

Uncertainty in estimates of outflows from the Great Lakes is dependent on the methods used to quantify each component and on the nature and magnitude of each outflow component. Only one diversion draws enough water to necessitate consideration in the Great Lakes water balance-the Chicago diversion.

\section{Connecting-Channel Flow}

The accurate measurement of connecting-channel flow is critical for reliable water-balance and NBS calculations by use of the residual method. Past study by Quinn (1979) indicates that the standard error in connecting-channel-flow measurements may be as low as 3-5 percent. However, many sources of uncertainty in calculating Great Lake outflow and inflow are unaccounted for in error analyses of flow measurements. This report takes a more detailed look at each individual connecting channel. The uncertainty in calculated flows for each connecting channel is dealt with on a river-by-river basis, because each channel has a unique set of properties and challenges regarding accurate calculation of flow.

\section{Lake Superior Outflow}

Lake Superior outflow through the St. Marys River is calculated as the sum of flows through several control structures at the twin cities of Sault Ste. Marie, Ontario and Michigan. Careful examination of figure 7 is helpful in understanding the accounting of flow in the St. Marys River. The components of outflow are (1) three hydropower plants, (2) the U.S. and Canadian Soo Navigation Locks, (3) the international dam known as the Compensating Works, including flow for fisheries habitat, and minor amount of water used for (4) municipal, and (5) industrial uses.

Historically, flows have been calculated at these structures primarily for the purpose of partitioning water allotments rather than for water-balance accounting. Calculating flow through so many structures undoubtedly adds to the technical complexity of accounting for net outflow from Lake Superior. Nevertheless, this accounting system has been used to estimate net outflow from Lake Superior for two main reasons. First, considerable resources are already being devoted to measuring flows here, and the current accounting system is considered adequate for regulatory needs. Second, calculating flow here dramatically lessens the difficulty of determining flow during winter. At any other point on the St. Marys River, wintertime ice prevents accurate measurement of flows. 
The largest component of flow through the St. Marys River at Sault Ste. Marie is the water flowing through the three hydropower plants. Two of these plants, the Edison-Sault and U.S. Government hydropower plants, are on the U.S. side of the river; the third, the Great Lakes Power Limited hydropower plant, is on the Canadian side. Accurate measurement of the powerplant flows is especially important to Lake Superior outflow estimates. Each plant calculates its diverted flow independently. In 2000, it was discovered that the reported flow through the U.S. Power and Edison Sault Electric Company power plants did not agree with flow measurements conducted by the Corps of Engineers and Environment Canada. The flows at the U.S. Government plant were being under-reported by about 9 percent (International Lake Superior Board of Control, 2001). The under-reporting at the Edison Sault Electric Company plant varied with the flow; smaller errors occurred at higher flows. This problem was detected as a result of an existing measurement program to verify flows, flow records have been corrected, and measures are being taken to prevent such miscalculations in the future (International Lake Superior Board of Control, 2002, 2003). Reported flows at the Great Lakes Power Limited plant were found to be within 7 percent of the independently measured values, with a mean error near zero, and are considered relatively accurate. Pending the successful implementation of new flow estimation practices at the U.S. Government hydropower plant, measurement of flows through the three powerplants will be relatively accurate, likely within 5 percent.

The next largest flow of St. Marys River water is through the Compensating Works. This dam is used to maintain water levels on Lakes Superior and Michigan-Huron close to historical levels and to prevent dramatic water-level fluctuations. The structure consists of 16 gates that can be opened and closed according to regulatory needs. A minimum of one-half gate $\left(2,830 \mathrm{ft}^{3} / \mathrm{s}\right)$ is kept open at all times to ensure sufficient water flow for fish spawning in the St. Marys Rapids. In practice, flow is regulated primarily by adjusting flow through the powerplants. Only when the powerplants are running at capacity is the flow increased by opening additional gates on the Compensating Works. The gates on the Compensating Works require regular maintenance, and leakage through the gates is inevitable. The U.S. Army Corps of Engineers (USACE) considers leakage to be $25 \mathrm{ft}^{3} / \mathrm{s}$ per gate and incorporates this flow in Lake Superior outflow calculations.

Significant amounts of water also flow through the Soo Navigation Locks. Of the four U.S. locks, only two are still in use: the Poe Lock and the MacArthur Lock. The Poe and MacArthur Lock chambers transfer a total of 2,825,000 $\mathrm{ft}^{3}$ and $1,413,000 \mathrm{ft}^{3}$ per lockage, respectively, less the water displaced by the ship in the lock. The one Canadian lock is much smaller than the U.S. locks and is primarily used for recreational boating. Flows through the locks are entered into the overall flow accounting for Lake Superior outflow. There has been no official statement of how accurate this system is. The seals on the lock doors also are prone to leakage, although to a lesser degree than the doors on the Compensating Works. Because of the relatively small amount of leakage, this quantity of water is not considered in Lake Superior outflow calculations. Uncertainty may result from not considering leakage from the locks.

The remaining components of flow through the St. Marys River are small diversions for municipal and industrial use. These quantities also are measured and incorporated into the total estimated St. Marys River flow. The accuracy of these measurements is likely to be adequate. These flows are so small that allocating significant resources to improve their measurement is impractical, especially when uncertainties regarding leakage through the locks and Compensating Works remain unquantified.

One approach to quantify the total uncertainty in Lake Superior outflow estimates is to assess the uncertainty in each component and sum the uncertainties. At this time, such an estimate is problematic. The largest impediment to making an accurate uncertainty determination is the unquantified leakage through the locks and Compensating Works. Until this flow is quantified, an accurate statement of uncertainty is difficult. However, the uncertainty in calculated monthly St. Marys River flow is likely to be greater than 5 percent and less than 15 percent.

An alternative to the current method of calculating Lake Superior outflow is to measure the river at another location. If accurately measured, researchers could assess and monitor long-term shifts in the uncertainty of the current accounting system. This method is not likely to be useful during winter because of ice-affected flows through the St. Marys River. However, a comparison of summertime flow estimates at the Soo structures with observations at an alternative location would be useful to verify the accuracy of current accounting methods during ideal conditions. One potential location to measure flows for the purpose of comparison is at the narrow section of the St. Marys River between Pointe aux Pins, Ontario, and Brush Point, Michigan (fig. 6).

\section{Lakes Michigan-Huron Outflow}

Water flows from Lakes Michigan-Huron to Lake Erie through the St. Clair River-Detroit River waterway (fig. 9). Unlike Lake Superior outflow, there are no control structures in this system, and flow must be measured in the existing river channel. Ice jams can severely complicate flow accounting in this river system and present major potential for uncertainty in calculated flows.

Three agencies currently estimate monthly flows through the St. Clair River-Lake St. Clair-Detroit River system; NOAA, USACE, and EC. Each of these three agencies has slightly differing methods of estimating these flows. Also, these agencies estimate river flow at many locations along the rivers. The uncertainty in all three agency estimates is largely due to the nature of stage-fall-discharge estimates. Most notably, ice floes and ice jams affect this relation and increase the uncertainty of flow calculations in the winter. Periodically, the three agencies meet and decide on which estimate is most accurate for each month. The agreed-upon value is then 
considered official. Generally, the values are in relatively close agreement during non-ice periods. The average range of MayNovember monthly values of flow from the three agencies is between 3.5 and 4 percent.

Estimating wintertime flows through this system can be considered the weak link in the chain of Lake Huron outflow accounting. The usual stage-fall-discharge equations used for the rivers cannot be applied to ice-affected flows, so alternative equations have been developed by each agency. The accuracy of these estimates remains unknown, although uncertainty is clearly higher than during periods of non-ice-affected flows. Official data for ice-affected flows are agreed upon in the same manner as non-ice-affected months, but the accuracy of these data is uncertain.

Measuring wintertime flow on the St. Clair River near Fort Gratiot using an Acoustic Doppler Current Profiler (ADCP) could be the best method to measure Lake Huron outflow during winter. Use of ADCP would allow the river to be gaged at one specific, ideal location. The St. Clair River near the gage at Fort Gratiot is relatively narrow, drops quickly, and flows swiftly, which prevents ice from forming and affecting flow. Flow velocities also are highly variable here, in response to changing flow volumes in the river.

Recent advances in instrumentation, including the use of ADCP technology by USACE and the renovation of many gaging stations on the St. Clair River by NOAA, may improve uncertainty in flow estimates. The function of ADCP measurements is to supply more reliable data on streamflow when developing stage-fall-discharge equations. The function of improving gaging stations at many locations on the river is to supply a wide range of reliable stage data when developing stage-fall-discharge equations. It is not yet clear if the placement of the ADCP is suitable to allow improved measurement of St. Clair River flow. Similarly, it is unclear which of the renovated gaging stations will supply the most useful data for stage-fall-discharge equations.

Useful flow estimates of lower St. Clair and Detroit Rivers could be generated using a computer model recently developed at the USGS (Holtschlag and Koschik, 2001). This model is capable of accurately estimating water levels and the distribution of flows throughout the St. Clair-Detroit River system, given accurate measurements of flow at model boundaries. The most important boundary in the USGS model is flow through the St. Clair River near the gaging station at Fort Gratiot, near the headwaters of the river. Additional flow boundaries include numerous tributary streams to the St. ClairDetroit River waterway, net atmospheric and ground-water inflow to Lake St. Clair, and water level at the mouth of the Detroit River near Bar Point, Ontario.

The USGS model could be used to estimate flows throughout the St. Clair-Detroit River waterway without investing a great deal of additional resources. Many of the inputs to this model, namely river stage measurements and tributary streamflows, are already being monitored and represent no additional allocation of resources. The current ADCP operated by the USACE also may be able to provide informa- tion necessary to estimate flow through the St. Clair River near the Fort Gratiot gaging station. However, the current ADCP is mounted vertically in the river channel. Because the USGS model is a horizontal 2-D model, a horizontally mounted $\mathrm{ADCP}$ would provide more relevant data. Also, the location of the ADCP is several miles downstream from the Fort Gratiot gaging station. It is unclear if river flows measured at this location will be adequate for use with the USGS model.

Estimating the uncertainty in Lakes Michigan-Huron outflow estimates is difficult or impossible. The close agreement in monthly non-ice-affected-flow estimates between USACE, NOAA, and EC (within 3.5-4.0 percent) indicates that relatively little uncertainty exists in these estimates. However, monthly estimates of ice-affected flows have much more uncertainty. At worst, uncertainty in monthly estimates of iceaffected flows could be many times the magnitude of non-iceaffected flows. It is not clear how much this affects average monthly estimates of Lakes Huron-Michigan outflow, because the existence and severity of ice on these rivers is highly variable over space and time. Also, it is not yet certain to what degree estimates have been improved by recent improvements in instrumentation. Without this information, only a reasonable range of uncertainty in current monthly runoff estimates can be stated, which is likely to be in the range of 5 percent to 15 percent.

\section{Lake Erie Outflow}

Lake Erie outflow is calculated by adding Niagara River flow at Buffalo to the flow entering the Welland Canal as it leaves Lake Erie (figs. 11 and 13). The Niagara River at Buffalo is not an ideal place to measure flows accurately, so flows at Buffalo are estimated based on several measurements made downstream. Periodic discharge measurements are made immediately upstream from the generating stations at Queenston, Ontario, and Lewiston, New York. Niagara River stage is measured at the Ashland Avenue gage near the downstream end of the Maid-of-the-Mist Pool below Niagara Falls

(fig. 11). These stage data are used together with the periodic discharge measurements to determine flow at the Maid-ofthe-Mist pool based on a stage-discharge relation. Flow at the Maid-of-the-Mist pool is combined with the outflow from the Sir Adam Beck 1 and 2 and the Robert Moses Niagara powerplants. The sum of these flows provides total Niagara River flow near Queenston. To calculate Niagara River flow at Buffalo, local inflow (between Buffalo and the Maid-of-the-Mist pool) and the amount of water diverted into the Niagara River from the Welland Canal are subtracted from the Queenston flows; then, the amount of water diverted into the NYSBC is added.

The amount of water entering the Welland Canal is based on a stage-discharge rating for flow through the Welland Canal Supply Weir combined with calculated flow through Lock 8, both in Port Colborne. The calculated Welland Canal flow at this point is considered to be the actual amount of diverted water. 
Eight distinct flows are calculated or estimated and then combined to determine Lake Erie outflow (nine different flows if the Sir Adam Beck powerplants 1 and 2 are considered separately). All components of this accounting system are labeled in the schematic in figure 13 and represented in equations 3-5.

$$
\begin{aligned}
& \mathrm{E}_{\mathrm{O}}=\mathrm{N}_{\mathrm{Buf}}+\mathrm{W}_{\mathrm{E}} \\
& \mathrm{N}_{\mathrm{Buf}}=\mathrm{N}_{\mathrm{MoM}}+\mathrm{P}_{\mathrm{B} 1 \text { and } 2}+\mathrm{P}_{\mathrm{RM}}-\mathrm{R}-\mathrm{W}_{\mathrm{d}}+\mathrm{B}_{\mathrm{c}} \\
& \mathrm{W}_{\mathrm{E}}=\mathrm{W}_{\mathrm{w}}+\mathrm{W}_{\mathrm{L} 8}
\end{aligned}
$$

Substitution of equations 4 and 5 into equation 3 yields equation 6 :

$$
E_{O}=N_{M o M}+P_{B \text { land2 }}+P_{R M}-R-W_{d}+B_{c}+W_{w}+W_{L 8}
$$

where $\mathrm{E}_{\mathrm{O}}$ is Lake Erie outflow,

$N_{B u f}$ is Niagara River flow at Buffalo,

$N_{M o M}$ is Niagara River Maid-of-the-Mist pool outflow, $W_{E}$ is Welland Canal flow at Lake Erie,

$W_{w}$ is Welland Canal flow through the supply weir structure,

$W_{L 8}$ is Welland Canal Lock 8 flow,

$W_{d}$ is Water diverted from the Welland Canal into the Welland River,

$P_{B 1 \text { and } 2}$ is flow through Sir Adam Beck 1 and 2 powerplants,

$P_{R M}$ is flow through Robert Moses powerplant,

$R$ is local inflow, and

$B_{c}$ is New York State Barge Canal flow.

This accounting system likely reduces the total uncertainty in Lake Erie outflow estimates but complicates assessment of total uncertainty. One interesting feature of these flow components is that only one of these flows is subject to ice and weed retardation, the Niagara River flow at the Maid-of-theMist pool.

Niagara River flows below the Maid-of-the-Mist pool $\left(N_{M o M}\right)$ are computed with stage measurements that are compared to an accepted stage-discharge relation curve. The types of uncertainty associated with this method of computing flow are basically the same as with other computations based on stage-discharge relations. Uncertainty in these measurements is currently unknown but is likely to average between 5 percent and 15 percent, depending on the degree to which ice and weeds affect the system. Maid-of-the-Mist pool outflow is the largest component of the Lake Erie outflow computation, constituting slightly less than 60 percent of the total Lake Erie outflow.
The outflow from the Sir Adam Beck 1 and 2 powerplants $\left(P_{B \text { 1and } 2}\right)$ and the Robert Moses Niagara powerplant $\left(P_{R M}\right)$ is based on power/output efficiency calculations. Ontario Power Generation (OPG) and New York Power Authority (NYPA) determine plant discharges using rating tables for generators. Detailed uncertainty analysis of flow through Sir Adam Beck 2 performed by OPG estimates uncertainty to be 2.33 percent (Ontario Power Generation, written communication, 2003). Uncertainty in Sir Adam Beck 1 and Robert Moses Niagara flow estimates is presumably similar. The sum flow through the three powerplants accounts for about 40 percent of the calculated Lake Erie outflow.

For accounting purposes, the amount of water diverted into the NYSBC $\left(B_{c}\right)$ has traditionally been assumed to be $1,100 \mathrm{ft}^{3} / \mathrm{s}$ during the navigation season. A lack of knowledge about how representative this value is of actual withdrawals for the NYSBC constitutes a significant data gap.

The amount of water diverted from the Welland Canal to the Niagara River $\left(W_{d}\right)$ is subtracted in equations 4 and 6 to avoid double counting this water as it flows through the Sir Adam Beck powerplants farther downstream. This flow is normally assumed to be $700 \mathrm{ft}^{3} / \mathrm{s}$. As a result of a recent test program by the City of Welland and the local conservation authority, however, the assumption was reduced to $460 \mathrm{ft}^{3} / \mathrm{s}$. When this change became known, flow records were revised to the beginning of 2002. An improved method of determining this diversion from the Welland Canal has been implemented (Len Falkiner, Environment Canada, written communication, 2004).

Local inflow $(R)$ into the Niagara River between Lake Erie and Queenston is taken into account by assigning a monthly value for runoff to each month rather than estimating local runoff each month on an ongoing basis. The reason for this practice is that streamflow records in the Niagara River Basin are inadequate to determine local inflow directly. The Coordinating Committee decided to assign an average monthly runoff value to each month of the year. The values assigned to each month are based on runoff records from the Grand River in Ontario and the Genesee River in New York during 1913-60. This procedure is described by the Coordinating Committee (1976, p. 14-15). Direct runoff to the Niagara River represents less than one half of 1 percent of the total calculated Lake Erie outflow. Because local runoff data are unavailable, there is currently no way of judging how well this system estimates local runoff.

Flow from Lake Erie to the Welland Canal is calculated by means of a stage-discharge relation based on measurement programs at the Welland Canal Supply Weir $\left(\mathrm{W}_{\mathrm{w}}\right)$ and calculated flow through Lock $8\left(\mathrm{~W}_{\mathrm{L} 8}\right)$. Flow through the 10 valves at the weir has been calibrated by the USACE and EC and is reviewed every few years. Rating equations have been developed that take into account the valve openings, the head differential from above and below the weir, and the elevation of Lake Erie. Flow through Lock 8 is computed as the number of lock cycles times the capacity of the lock relative to the head differential. Hydraulic assists to shipping also are added and 
taken into consideration in the lock flow accounting. Official Welland Canal data reports do not show whether this system considers the amount of water that each ship displaces in the lock. If water displacement is not taken into consideration, Welland Canal flow will be overreported. The uncertainty in Welland Canal component of Lake Erie outflow is currently unknown but is likely to be in the range of 10 percent to 20 percent. The uncertainty in Welland Canal flow data could potentially be reduced by use of acoustic velocity metering (AVM) technology. The value of reducing the uncertainty in Welland Canal flow estimates to improving Lake Erie outflow estimates is questionable, however, because the total flow through the Welland Canal accounts for less than 5 percent of Lake Erie outflow.

Overall, the uncertainty of the Lake Erie outflow calculation is dominated by the uncertainty in the calculated Maidof-the-Mist outflow and discharges from the powerplants. Taking this into consideration, the total uncertainty in Lake Erie outflow is likely to be between 4 to 10 percent. Use of ADCP technology to measure the Niagara River could possibly reduce the uncertainty to some extent. The accuracy of estimates of the smaller components has the potential to be improved substantially; the practicality of this is questionable, however, because improvement of total uncertainty of Lake Erie outflow would likely be negligible.

\section{Lake Ontario Outflow}

Water flows from Lake Ontario to the Atlantic Ocean through the St. Lawrence River. Flow through the river is measured at the Moses-Saunders powerplant. Detailed uncertainty analysis of flow through the Moses-Saunders facility performed by OPG estimates uncertainty to be 1.24 percent (Ontario Power Generation, written communication, 2003). This degree of accuracy is possible because nearly 100 percent of the river flows through the 32 turbines of the power dam, and the turbine hydraulics are very well known. The flows are not subject to change due to ice floes, weed effects, or changes in the river channel.

Estimated flow at the Moses-Saunders powerplant is generally taken as Lake Ontario outflow even though this site is 112 mi downstream from the outlet of Lake Ontario at Kingston, Ontario. No attempt is made to compensate for local runoff between Kingston and Cornwall; from a management perspective, it may be convenient or even desirable to treat the Moses-Saunders hydropower plant as the downstream terminus of the Lake Ontario Basin. Overall, uncertainty in Lake Ontario outflow estimates at Moses-Saunders is less than 2 percent.

\section{Evaporation}

Evaporation from the Great Lakes is perhaps the single most difficult process in the Great Lakes hydrologic cycle to understand. Added to this difficulty is the size of the Great Lakes. Quantifying evaporation over parts of the lakes that may be tens of miles away from land is a difficult task. Considering that evaporation is greater in magnitude than runoff, assessing the current understanding of evaporation from the Great Lakes is of great importance.

Evaporation from the Great Lakes is not directly measured, but it is estimated by means of the Great Lakes Evaporation Model, which was developed at the Great Lakes Environmental Research Laboratory (GLERL) (Croley, 1989a, b; 1992; Croley and Assel, 1994). This model incorporates observations on many atmospheric and hydrologic parameters and generates an estimate for evaporation from the surface of each lake, plus Georgian Bay. Most of the data used for the model are collected at weather stations near the shoreline of the Great Lakes; however, the model also uses remotely sensed data in the form of satellite-based surface-water temperatures. The model is a "lumped" model of heat storage, meaning that it estimates average evaporation rates for an entire body of water. Unlike a distributed model of a water body, the Great Lakes Evaporation Model does not estimate evaporation at specific points on the Great Lakes.

Uncertainty has been estimated for many of the input variables of the Great Lakes Evaporation Model, but no official statement of the accuracy of evaporation estimates is currently available. Any attempt to verify the model using discrete (point) evaporation estimates made over a Great Lake must attempt to identify an average evaporation rate for the entire Lake. In a system as large as the Great Lakes, this can be a daunting challenge technically, logistically, and financially. Such a jump from discrete data to an average evaporation rate for the entire lake also would introduce considerable uncertainty to the estimate being used to verify the model. Consequently, verifying the Great Lakes Evaporation Model is not a straightforward task.

One facet of the model that could be verified is the validity of using shore-based meteorological measurements to represent over-lake conditions. It is conceivable that the evaporation model could be run two times a month for verification purposes; first, using the current system of shore-based measurements and second, using measurements made over the lake using buoys or other research platforms. Comparing the resulting evaporation estimates would reveal biases resulting from variations in the input data. Such a comparison would be useful to assess the adequacy of current methods of generating input data for the evaporation model.

An accurate estimate of uncertainty in the Great Lakes Evaporation Model is difficult to make at this time. However, for the purpose of considering evaporation estimate uncertainty in NBS estimates, an uncertainty range of 10 percent to 35 percent is assumed.

If it is deemed necessary to improve current evaporation estimates, there are at least two basic approaches: improving input data for the current model and improving or replacing the current model. The clearest way to improve the current evaporation model is to improve the quality of the input data. Greater use of over-lake or remotely sensed measurements on a year-round basis deserves some consideration. 
The second approach to improving evaporation estimates is to use an improved evaporation model. Many distinct methods for estimating evaporation have been developed, and the accuracies differ considerably (Winter and others, 1995). The more reliable methods tend to require a greater variety of input data and more extensive instrumentation; therefore, if more resources were devoted to monitoring the physical hydrology of the Great Lakes, a more reliable model could possibly be developed.

\section{Diversions}

Of the numerous diversions of water from the Great Lakes, only two are large enough to significantly affect the water balance: the Chicago diversion, which transports water out of the Great Lakes Basin; and the Welland Canal, which transports water from Lake Erie to Lake Ontario. The Welland Canal is treated as part of Lake Erie outflow in the water balance. For this reason, uncertainties in measuring Welland Canal flows are discussed at length in the "Connecting-Channel Flow" section of this report. Only the Chicago diversion will be discussed in this section.

Currently, accounting for water diverted from Lake Michigan at Chicago considers (1) pumpage from Lake Michigan that is used for domestic purposes and routed out of the basin, (2) runoff that is redirected to flow out of the basin, and (3) direct diversions through three lakefront control structures. Domestic wastewater is treated and routed into the Chicago Sanitary and Ship Canal (CSSC) system. Construction of the Chicago diversion has rerouted the runoff from $673 \mathrm{mi}^{2}$ of Great Lakes Basin to flow out of the basin. Water is diverted directly from Lake Michigan at three locations, the Chicago River Controlling Works, the Thomas J. O'Brien Lock and Dam, and the Wilmette pumping station (U.S. Army Corps of Engineers, 2001, p. 7).

The accounting system for the Chicago diversion is summarized in equation 7 . This system is the product of a considerable history of litigation and is intended to satisfy a U.S. Supreme Court decree that limits diversion flows attributable to the State of Illinois. Figure 16 illustrates the points of withdrawal, and the points of measurement of the Chicago diversion.

$$
D_{c}=Q_{R}+D_{m}-R_{D P}-Q_{G W}-I_{G W}
$$

where $D_{c}$ is total discharge from the Chicago diversion,

$Q_{R}$ is measured streamflow at Romeoville,

$D_{m}$ is municipal and miscellaneous discharge of diversion water not measured at the Romeoville gaging station,

$R_{D P}$ is runoff from the Des Plaines River that discharges into the CSSC upstream from Romeoville gaging station,

$Q_{G W}$ is the portion of the flow at Romeoville that originated as ground water that was pumped for Illinois municipal use and discharged to the CSSC or attributed to ground-water seepage into the canal, and

$I_{G W}$ is Indiana water discharge to the CSSC from the Calumet River system and the Calumet Sag Channel.

More than 90 percent of all flows diverted at Chicago pass the gaging station at Romeoville and are measured by AVM. Diverted flows not captured in this channel include treated wastewater discharged from communities that do not release their wastewater into the canal. Domestic and miscellaneous discharge of diversion water is estimated and added to the streamflow at Romeoville (U.S. Army Corps of Engineers, 2001, p. 7).

Flow measured at the Romeoville gaging station also captures non-Great Lakes Basin water from three sources (U.S. Army Corps of Engineers, 2001, p. 8). Before Chicago diversion accounting can be complete, these three sources must be discounted from the Romeoville flows. First, stormwater discharge from the Des Plaines River Basin is captured in the Chicago stormwater system, treated, and discharged to the CSSC upstream from the gaging station at Romeoville. The routing of this water is not apparent on the map in figure 16 , but this stormwater must still be subtracted from Romeoville flows. The second source of non-Great Lakes water in Romeoville gaged flows is ground water. Ground-watersupply effluent from Illinois and ground-water seepage into tunnels that flow to the CSSC are considered to be "non-Great Lakes Basin water" under the U.S. Supreme Court decree that regulates Chicago diversion accounting. Third, Indiana water supply that is discharged to the CSSC from the Calumet River system and the Calumet Sag Channel is discounted. This also is an accounting detail attributable to the U.S. Supreme Court decree that dictates the legal accounting of the diversion.

There are four primary categories of uncertainty in the official Chicago diversion accounting. First is the uncertainty associated with the measurement of CSSC flows at Romeoville. These flows are measured directly with an AVM. Such measurements are commonly believed to be reliable within 5 percent. The second category of uncertainty is in the estimates of discharge from several water-treatment plants in the system. Flows through the treatment plants are closely monitored by means of water balances and then usually compared to recorded flows to ensure accuracy (U.S. Army Corps of Engineers, 2001, p. 8). This system is generally accepted as being effective, and the uncertainty is likely to be in the range of 5 percent-10 percent, although the actual uncertainty has not been officially established. The third category of uncertainty in the Chicago diversion accounting system is the estimation of the ground-water component of Romeoville streamflow. Most of this component is measured as ground water pumped for Chicago water supplies, and some of it is calculated as seepage into the system (U.S. Army Corps of Engineers, 2001). The quantity of water in this category is comparatively small, so the uncertainty in its estimation is of minor importance to the total uncertainty of the accounting 
method. The fourth and final category of uncertainty is the estimation of water supplies from Indiana. These flows are not gaged; they fluctuate as the elevation of Lake Michigan changes, and they are probably the least understood flows in the Chicago diversion system.

The official Chicago diversion accounting dictated by the U.S. Supreme Court applies directly to Illinois and does not count diversion flows arising from three specific sources. The first source is pumpage of Lake Michigan waters by U.S. Federal facilities. The second source is diverted flow from Indiana. Finally, ground water pumped from inside the Great Lakes Basin that is ultimately diverted outside the Great Lakes Basin (U.S. Army Corps of Engineers, 2001, Appendix B, p. 21-23). According to data reported by USACE (2001, p. 21), the sum of these three flows in water year 1995 totaled 4 percent of the total diversion flow accountable to Illinois. Therefore, certified flow statistics systematically underestimated the total flow of water diverted at and near Chicago by 4 percent for water year 1995. The magnitude of this bias is believed to be similar in other years of reporting.

There also are two small over deductions in certified diversion flow statistics. Mathematically, diversion amounts should be deducted by the quantity of consumptive use within the basin; that is, water consumed inside the basin should not count toward water diverted out of the basin. Currently (2004), engineers are unable to calculate consumptive use well enough to estimate a fair and reliable deduction; therefore, this amount is not deducted in certified Chicago diversion flows (U.S. Army Corps of Engineers, 2001, p. 23-24). This unknown but small amount should not contribute significantly to the total uncertainty in the Chicago diversion. The second over deduction happens when runoff to the Chicago diversion is counted 100 percent as diverted water; despite the belief that evapotranspiration would diminish the amount of runoff that would naturally reach Lake Michigan. The degree to which these over deductions are significant is a matter of debate. For example, Croley and others (2001) consider the current accounting of diverted runoff to cause a significant overstatement in the amount of water removed from Lake Michigan. For a more in-depth discussion of the Chicago diversion computation procedures, the reader is directed to the latest Chicago District USACE publication titled, "Lake Michigan diversion accounting, water year [YEAR] annual report” (for example, U.S. Army Corps of Engineers, 2001).

For the purpose of illustrating the importance of Chicago diversion accounting uncertainty in NBS estimates, a reasonable range of uncertainty in the official Chicago diversion accounting method is assumed to be in the range of 5 percent to 10 percent. There is also a 4 percent under-reporting bias related to water diverted away from Lake Michigan through Indiana.

\section{Change in storage}

Net change in storage is calculated as the product of the measured change in lake stage and surface area of each lake. Therefore, the uncertainty in change-in-storage calculations depends on the accurate measurement of these two parameters. Estimates of the surface area of the Great Lakes exist in Coordinating Committee (1977, table 1). Some amount of uncertainty is present in these data, but these measurements are generally taken as adequate to calculate change in storage on the Great Lakes. Uncertainty in lake-stage measurements is responsible for some uncertainty in change-in-storage estimates. Thermal expansion and contraction of water also contributes to uncertainty in estimates of change in storage.

Computation of lake-stage data is complicated primarily by two processes-isostatic rebound and wind set-up and seiche. The USACE adjusts its computation of average lake stage for isostatic rebound, so this factor is not believed to contribute a significant amount of uncertainty to change-in-storage estimates. The previously described phenomena of wind set-up and seiche can cause great variability in lake stage at different parts of a lake. The method used to correct for these factors is to measure lake stage at selected locations and average the values in a weighted fashion to determine an average lake stage (Croley, 1987a, 1987b). The locations of all active lake gages are shown in figure 19. The Marine Environmental Data Service (MEDS) and the National Ocean Service (NOS, a division of NOAA) report Great Lakes stage measurements at individual gages throughout the basin. The uncertainties of these agencies' stage data are $10 \mathrm{~mm}$ (0.39 in) and $5 \mathrm{~mm}(0.20 \mathrm{in})$ at individual gages, respectively. However, it is a weighted average of many gages around a given Great Lake that yields the "true" lake stage that is used in change-in-storage calculations.

The USACE reports "normalized daily mean" water levels of the Great Lakes. These average daily values, which are generated from a coordination of the measurements of selected U.S. (NOS) and Canadian (MEDS) gages, consider the heterogeneous effect of isostatic rebound on the gage network. Beginning-of-month (BOM) lake stage is based on these USACE data and is determined by averaging the first day of the month with the last day of the previous month (Lee, 1992). The resulting BOM values are used to calculate monthly change in storage. The USACE does not publish an official statement of uncertainty in these data (Neff and Killian, 2003). However, statistically speaking, the uncertainty in these average stage data should be substantially smaller than the uncertainty of any one gage measurement. The uncertainty in the normalized daily mean lake-stage data is likely to be in the range of $2.0 \mathrm{~mm}$ (0.079 in). Croley (1987a, 1987b) points out that uncertainty from wind set-up is greatest in the fall and winter, when wind is more common than in spring or summer. Uncertainty is likely to be greater in individual months with nonideal weather and hydrologic conditions.

Whatever the uncertainty of the BOM mean stage, it must be remembered that change in storage is based on two separate BOM stage measurements (beginning and end of month measurements) and that both uncertainties must be summed statistically. 


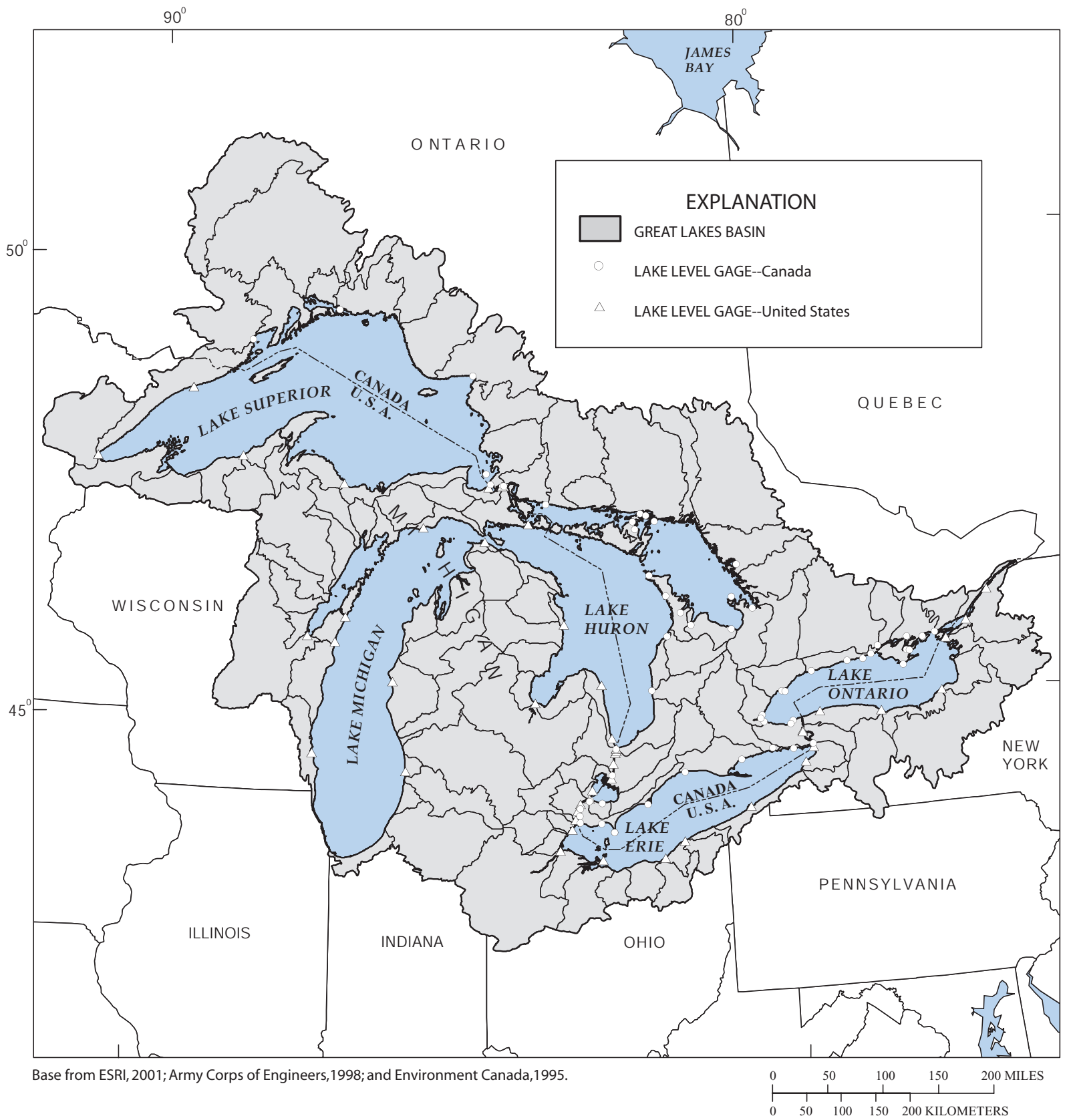

Figure 19. Locations of lake level gages in the Great Lakes basin.

(Canadian data from Marine Environmental Data Service, 2002; U.S. data from National Ocean Service, 2002.) 
Specifically, the uncertainty of the change-in-storage calculation increases beyond the uncertainty of one stage measurement. The statistical sum of the uncertainties related to lake-stage measurement data is likely to be within the range of $\pm 3 \mathrm{~mm}$ (0.118 in).

One fundamental assumption in the change-in-storage calculation is that the thermal expansion or contraction of water is negligible. Water physically expands and contracts slightly in response to changes in temperature. Some researchers have shown that this fluctuation can become significant during some months of the year. Meredith (1975) and Quinn and Guerra (1986) used water-column temperature data to calculate monthly rates of thermal expansion of water in Lake Erie. Their results show that change in storage caused by thermal expansion and contraction can be as high as $106 \mathrm{~m}^{3} / \mathrm{s}\left(3,743 \mathrm{ft}^{3} / \mathrm{s}\right.$; Meredith, $1975)$ and $131 \mathrm{~m}^{3} / \mathrm{s}\left(4,626 \mathrm{ft}^{3} / \mathrm{s}\right.$; Quinn and Guerra, 1986) for some months. Based on the area of Lake Erie presented in Coordinating Committee (1977), these rates are equivalent to a change in lake stage of approximately $10 \mathrm{~mm}$ (0.39 in) in one month. Lee (1992, p. 9 and 11) notes that significant error in change-in-storage estimates can result if thermal expansion of water is not considered and recommends that it be considered in NBS calculations.

Incorporating thermal expansion and contraction of the Great Lakes into change-in-storage calculations could be done two ways. The first and most simple method would be to use the estimated water-column data generated by the Great Lakes Evaporation Model, described previously, to calculate the thermal expansion or contraction of each Great Lake. The second way would require extensive monitoring of water-column temperatures. On the basis of published estimates of rates of thermal expansion of water in Lake Erie, it is possible that this process is insignificant during most months, but could cause an uncertainty of $10 \mathrm{~mm}(0.39 \mathrm{in})$ in monthly change-in-storage calculations in a worst-case scenario.

Changes in salinity of water and depth also affect water density and are therefore of theoretical concern. However, these factors affect the Great Lakes system either very little or on time scales that are long term. For these reasons, changes in water density due to these factors are not considered here.

The two largest impediments to the development of an accurate uncertainty estimate are (1) the lack of an official statement of uncertainty in USACE-generated normalized daily mean stage data and (2) the need for additional information on the thermal expansion and contraction of the Great Lakes. In the absence of this information, it is apparent that for most months the uncertainty in monthly change-in-storage calculations could be as low as $3 \mathrm{~mm}$ (0.12 in), but for some months the uncertainty could be as high as $12 \mathrm{~mm}(0.47 \mathrm{in})$.

\section{Current Approaches to Deriving Net Basin Supply}

NBS can be thought of qualitatively as the net amount of water entering a Great Lake. This section describes the two methods of calculating NBS and considers how the uncertainties in the water-balance equation affect each method. A tabular comparison of the uncertainties also is given.

Two distinct approaches, the residual method and the component method, can be used to determine NBS. The methods differ in the water-balance components used to determine NBS. Each approach is better suited for certain situations than the other. Understanding the difference between the two methods is a key to maximizing the accuracy of NBS estimates. Mathematical expressions of the complete accounting of NBS for each method are given in equations 8 and 10. Simplified, commonly used expressions, in which terms considered to be negligible are omitted, are given in equations 9 and 11 . Omission of these terms has substantial implications for the uncertainty of NBS estimates. The reader should be aware that both methods consider several components of the water balance, and that "components of the water balance" should not be confused with "the component method." Readers also are directed to Lee (1992) for additional information on the two methods.

Component NBS calculation - full

$N B S=P+R-E+G$

Component NBS calculation - commonly used

$N B S=P+R-E$

Where $P$ is over-lake precipitation,

$R$ is runoff to a Great Lake,

$E$ is evaporation from the lake surface, and

$G$ is ground-water flux into a Great Lake (net).

Residual NBS calculation - full

$N B S=O-I+\Delta S-\Delta S_{t}+D_{o}-D_{i}$

Residual NBS calculation - commonly used

$N B S=O-I+\Delta S+D_{o}-D_{i}$

Where $O$ is outflow from a given Great Lake,

$I$ is inflow from an upstream Great Lake (the water balance for Lake Superior does not have an I term),

$\Delta S$ is change in water storage of a Great Lake,

$\Delta S_{t}$ is change in water storage caused by thermal expansion or contraction of the water body,

$D_{o}$ is diversion of water out of a basin, and

$D_{i}$ is diversion of water into a basin.

Note the similarity between the residual method equations (10 and 11) and the traditional water-balance equation (Inflow = Outflow $+\Delta$ Storage). In fact, these equations are conceptually the same. Also, note that the residual method NBS is equal to the component method NBS; subtracting one from the other should yield zero.

Consumptive use requires mention with regard to these equations. Consumptive use represents water that is supplied to a basin but is frequently removed before it can be accounted for by 
other terms of the water balance. In many instances, but not all, it should be added to both the residual and the component NBS equations. For example, if water is removed from the headwaters of a river and consumed, it should be added to residual and component NBS estimates. However, if water is removed directly from a Great Lake and consumed, the quantity of water should be added to the residual NBS, but not to the component NBS, because the component method has already accounted for this water as runoff or precipitation. This point is somewhat moot and perhaps is best ignored in practice; no estimates of NBS attempt to account for consumptive use, and the magnitude of consumptive use is relatively small.

\section{Component NBS}

The component method calculates NBS by considering the actual inputs and outputs of each lake, without regard to connecting-channel flow or change in storage. Usually, the component NBS is calculated simply as $N B S=P+R-E$. The disadvantage to this method is that runoff, direct precipitation, and evaporation tend to be the elements of the water balance prone to the greatest percentage of uncertainty. The advantage to this method is that it avoids the need to measure flow through the connecting channels and change in storage. Even though the uncertainty in connecting-channel flow can be a relatively small percentage, the amount of flow being measured is relatively large, which can result in large total uncertainties.

Although it is theoretically not necessary to consider diversion flow when using the component method, existing datasets of runoff and diversion flows necessitate their consideration. Streamflow entering Lake Superior from the Nipigon and Aquasabon Rivers include water diverted from the Ogoki and Long Lac diversions, respectively (figs. 4 and 5). There is no way to accurately measure runoff from these rivers without inadvertently measuring Ogoki and Long Lac diversion flows. However, it is possible to subtract Ogoki and Long Lac diversion flows from the total runoff to Lake Superior. This method yields the true Great Lakes Basin runoff from the Nipigon River with the least possible uncertainty.

Flows through the Chicago diversion are dealt with differently than flows through the Ogoki and Long Lac diversions in component method NBS calculations. The simplest way to account for the Chicago diversion is to calculate runoff for all areas within the Lake Michigan Basin, including areas that are now diverted to the Mississippi River Basin at Chicago. Runoff from the Chicago area can be calculated using data provided in the latest Chicago District USACE publication titled, "Lake Michigan diversion accounting, water year [YEAR] annual report" (for example, U.S. Army Corps of Engineers, 2001). These runoff data can then be used to calculate NBS using the component method (eq. 9). A different way to account for Chicago diversion flows when calculating NBS using the component method is used by some authors (Croley and others, 2001, p. 7-8).

Because the Welland Canal diversion is an interbasin diversion between Lake Erie and Lake Ontario, it is not treated as a diversion in either method of NBS estimation. In residual NBS estimates, it is lumped together with Niagara River flows to generate total Lake Erie outflow. The component method does not consider Welland Canal flows in any way.

Ground-water discharge to the Great Lakes and consumptive use within the Great Lakes Basin comprise part of NBS, but are generally assumed to be negligible. These components are not considered in any existing NBS calculations. As shown elsewhere in this report, these assumptions may introduce some uncertainty to NBS estimates.

GLERL computes NBS on the basis of the component method and publishes the results periodically. The most recent published NBS data are in Croley and others (2001). The Midwestern Regional Climate Center (MRCC) also publishes a forecast of Great Lakes NBS based on the component method on their Web site (http://mcc.sws.uiuc.edu); this Web site is briefly described in Neff and Killian (2003, p. 21, 27).

\section{Residual NBS}

The residual method of calculating NBS considers connecting-channel inflow and outflow and the change in storage of each lake. For a complete accounting of NBS, adjustments need to be made to account for the change in storage caused by thermal expansion, diversions into and out of the Great Lakes, and consumptive use. Usually, however, thermal expansion and consumptive use are considered to be negligible and are treated as zero (equations 10-11).

The advantage to calculating NBS with the residual method is that only water levels on the Great Lakes and flows in the connecting channels need to be measured to generate an estimate of NBS. This is both convenient and a relatively straightforward way to calculate NBS. The main problem with this method is that connecting-channel flows and change in storage in the Great Lakes system are very large in relation to NBS estimates. This issue is amplified in the lower reaches of the Great Lakes system. Therefore, even a small degree of uncertainty in the connectingchannel flow and change-in-storage estimates can cause a large degree of uncertainty in the calculated NBS. Quinn and Guerra (1986) showed that a 5-percent error in Lake Erie connectingchannel flow can result in a disproportionately large error in NBS calculation.

The way diversions are accounted for is the second problem with residual-method NBS estimates. Ideally, only the part of the diversion that actually affects a lake would be counted in equations 10 and 11. However, this is not always possible, and agencies reporting residual-method NBS estimates simply consider diversion flow data as is, without making adjustments in their calculations. This practice adds uncertainty to the NBS estimates.

\section{Relative Magnitude of Uncertainties in NBS Estimates}

Tables 3-7 and figures 20-21 summarize the findings of this report and illustrate how uncertainty in estimates of individual 
Table 3. Summary of monthly component and net basin supply (NBS) uncertainty for Lake Superior [ft $3 / \mathrm{s}$, cubic feet per second; in, inches; mm, millimeters; \%, percent; N/A, not applicable].

\begin{tabular}{|c|c|c|c|c|c|}
\hline \multirow{2}{*}{$\begin{array}{c}\text { Lake Superior } \\
\text { Component of water balance }\end{array}$} & \multirow{2}{*}{$\begin{array}{r}\text { Average } \\
\text { magnitude } \\
\mathrm{ft}^{3} / \mathrm{s}\end{array}$} & \multicolumn{4}{|c|}{$\begin{array}{l}\text { Average monthly } \\
\text { estimate uncertainty }\end{array}$} \\
\hline & & Low & High & Low $\left(\mathrm{ft}^{3} / \mathrm{s}\right)$ & $\operatorname{High}\left(\mathrm{ft}^{3} / \mathrm{s}\right)$ \\
\hline Connecting-channel inflow & N/A & N/A & N/A & N/A & N/A \\
\hline Connecting-channel outflow & 79,118 & $5 \%$ & $15 \%$ & 3,956 & 11,868 \\
\hline Change in storage & N/A & 0.12 in $(3 \mathrm{~mm})$ & 0.47 in $(12 \mathrm{~mm})$ & 3,356 & 13,422 \\
\hline Over-lake precipitation & 73,047 & $15 \%$ & $45 \%$ & 10,957 & 32,871 \\
\hline Runoff & 55,619 & $15 \%$ & $35 \%$ & 8,343 & 19,467 \\
\hline Evaporation & 54,233 & $10 \%$ & $35 \%$ & 5,423 & 18,982 \\
\hline Long Lac diversion & 1,412 & $10 \%$ & $30 \%$ & 141 & 424 \\
\hline Ogoki diversion & 4,035 & $10 \%$ & $30 \%$ & 404 & 1,211 \\
\hline Ground water & Unknown & $100 \%$ of $850 \mathrm{ft}^{3} / \mathrm{s}$ & $100 \%$ of $3,500 \mathrm{ft}^{3} / \mathrm{s}$ & 850 & 3,500 \\
\hline Component NBS & 70,398 & $11 \%$ & $31 \%$ & 7,567 & 21,848 \\
\hline Residual NBS & 73,671 & $4 \%$ & $12 \%$ & 2,656 & 9,164 \\
\hline
\end{tabular}

Table 4. Summary of monthly component and net basin supply (NBS) uncertainty for Lakes Michigan-Huron [ft3/s, cubic feet per second; in, inches; mm, millimeters; \%, percent; N/A, not applicable].

\begin{tabular}{|c|c|c|c|c|c|}
\hline \multirow{2}{*}{$\begin{array}{c}\text { Lakes Michigan-Huron } \\
\text { Component of water balance }\end{array}$} & \multirow{2}{*}{$\begin{array}{r}\text { Average } \\
\text { magnitude } \\
\mathrm{ft}^{3} / \mathrm{s} \\
\end{array}$} & \multicolumn{4}{|c|}{$\begin{array}{c}\text { Average monthly } \\
\text { estimate uncertainty }\end{array}$} \\
\hline & & Low & High & Low $\left(\mathrm{ft}^{3} / \mathrm{s}\right)$ & $\operatorname{High}\left(\mathrm{ft}^{3} / \mathrm{s}\right)$ \\
\hline Connecting-channel inflow & 75,430 & $5 \%$ & $15 \%$ & 3,772 & 11,315 \\
\hline Connecting-channel outflow & 183,810 & $5 \%$ & $15 \%$ & 9,191 & 27,572 \\
\hline Change in storage & N/A & 0.12 in $(3 \mathrm{~mm})$ & 0.47 in $(12 \mathrm{~mm})$ & 4,796 & 19,182 \\
\hline Over-lake precipitation & 106,610 & $15 \%$ & $45 \%$ & 15,992 & 47,975 \\
\hline Runoff & 95,170 & $15 \%$ & $35 \%$ & 14,275 & 33,310 \\
\hline Evaporation & 83,410 & $10 \%$ & $35 \%$ & 8,341 & 29,194 \\
\hline Chicago diversion & 3,200 & $5 \%$ & $10 \%$ & 160 & 320 \\
\hline Ground water & Unknown & $\begin{array}{r}100 \% \text { of } 1,625 \\
\mathrm{ft}^{3} / \mathrm{s}\end{array}$ & $100 \%$ of $6,500 \mathrm{ft}^{3} / \mathrm{s}$ & 1,625 & 6,500 \\
\hline Component NBS & 118,370 & $10 \%$ & $28 \%$ & 11,765 & 33,478 \\
\hline Residual NBS & 111,580 & $5 \%$ & $16 \%$ & 5,629 & 18,084 \\
\hline
\end{tabular}


Table 5. Summary of monthly component and net basin supply (NBS) uncertainty for Lake Erie [ft3 $/ \mathrm{s}$, cubic feet per second; $\mathrm{m}^{3} / \mathrm{s}$, cubic meters per second; in. inches; mm, millimeters; \%, percent; N/A, not applicable].

\begin{tabular}{|c|c|c|c|c|c|}
\hline \multirow[b]{2}{*}{ Component of water balance } & \multirow{2}{*}{$\begin{array}{r}\begin{array}{r}\text { Average } \\
\text { magnitude }\end{array} \\
\mathrm{ft}^{3} / \mathrm{s} \\
\end{array}$} & \multicolumn{4}{|c|}{$\begin{array}{c}\text { Average monthly } \\
\text { estimate uncertainty }\end{array}$} \\
\hline & & Low & High & $\begin{array}{r}\text { Low } \\
\left(\mathrm{ft}^{3} / \mathrm{s}\right) \\
\end{array}$ & $\begin{array}{r}\text { High } \\
\left(\mathrm{ft}^{3} / \mathrm{s}\right) \\
\end{array}$ \\
\hline Connecting-channel inflow & 188,333 & $5 \%$ & $15 \%$ & 9,417 & 28,250 \\
\hline Connecting-channeloutflow & 206,202 & $4 \%$ & $10 \%$ & 8,248 & 20,620 \\
\hline Change in storage & N/A & 0.12 in $(3 \mathrm{~mm})$ & $0.47 \mathrm{in}(12 \mathrm{~mm})$ & 1,049 & 4,197 \\
\hline Over-lake precipitation & 25,497 & $15 \%$ & $45 \%$ & 3,825 & 11,474 \\
\hline Runoff & 21,189 & $15 \%$ & $35 \%$ & 3,178 & 7,416 \\
\hline Evaporation & 26,027 & $10 \%$ & $35 \%$ & 2,603 & 9,109 \\
\hline Ground water & Unknown & $100 \%$ of $400 \mathrm{ft}^{3} / \mathrm{s}$ & $100 \%$ of $1,600 \mathrm{ft}^{3} / \mathrm{s}$ & 400 & 1,600 \\
\hline Component NBS & 20,659 & $14 \%$ & $41 \%$ & 2,871 & 8,417 \\
\hline Residual NBS & 17,869 & $36 \%$ & $101 \%$ & 6,412 & 17,991 \\
\hline
\end{tabular}

Table 6. Summary of monthly component and net basin supply (NBS) uncertainty for Lake Ontario [ft $3 / \mathrm{s}$, cubic feet per second; in, inches; mm, millimeters; \%, percent; N/A, not applicable]

\begin{tabular}{|c|c|c|c|c|c|}
\hline \multirow{2}{*}{$\begin{array}{c}\text { Lake Ontario } \\
\text { Component of water balance }\end{array}$} & \multirow{2}{*}{$\begin{array}{r}\text { Average } \\
\text { magnitude } \\
\mathrm{ft}^{3} / \mathrm{s}\end{array}$} & \multicolumn{4}{|c|}{$\begin{array}{l}\text { Average monthly } \\
\text { estimate uncertainty }\end{array}$} \\
\hline & & Low & High & Low $\left(\mathrm{ft}^{3} / \mathrm{s}\right)$ & $\operatorname{High}\left(\mathrm{ft}^{3} / \mathrm{s}\right)$ \\
\hline Connecting-channel inflow & 206,202 & $4 \%$ & $10 \%$ & 8,248 & 20,620 \\
\hline Connecting-channel outflow & 246,461 & $1.5 \%$ & $2 \%$ & 3,697 & 4,929 \\
\hline Change in storage & N/A & 0.12 in $(3 \mathrm{~mm})$ & 0.47 in $(12 \mathrm{~mm})$ & 777 & 3,108 \\
\hline Over-lake precipitation & 18,081 & $15 \%$ & $45 \%$ & 2,712 & 8,136 \\
\hline Runoff & 37,539 & $15 \%$ & $35 \%$ & 5,631 & 13,139 \\
\hline Evaporation & 14,091 & $15 \%$ & $45 \%$ & 2,114 & 6,341 \\
\hline Ground water & Unknown & $100 \%$ of $300 \mathrm{ft}^{3} / \mathrm{s}$ & $100 \%$ of $1,250 \mathrm{ft}^{3} / \mathrm{s}$ & 300 & 1,250 \\
\hline Component NBS & 41,530 & $8 \%$ & $21 \%$ & 3,370 & 8,546 \\
\hline Residual NBS & 40,259 & $12 \%$ & $27 \%$ & 4,631 & 10,951 \\
\hline
\end{tabular}


water-balance components affects uncertainty in monthly NBS estimates. Each table presents estimates of the reasonable range of percent uncertainty of each component as determined elsewhere in this report. The total uncertainty of each component is calculated by multiplying percent uncertainty by the long-term average magnitude of each component as determined from data reported by Croley and others (2001). In the case of ground water, the total uncertainty is 100 percent of net seepage. The range of total seepage for each lake is based on reasonable rates of seepage per mile of shoreline $\left(0.5 \mathrm{ft}^{3} / \mathrm{s}-2.0 \mathrm{ft}^{3} / \mathrm{s}\right)$ and the lengths of shoreline of each lake as reported by the Coordinating Committee (1977). Uncertainties related to consumptive use are not reflected here. Data given for total uncertainty in NBS estimates is the statistical sum of the uncertainties of each compo-

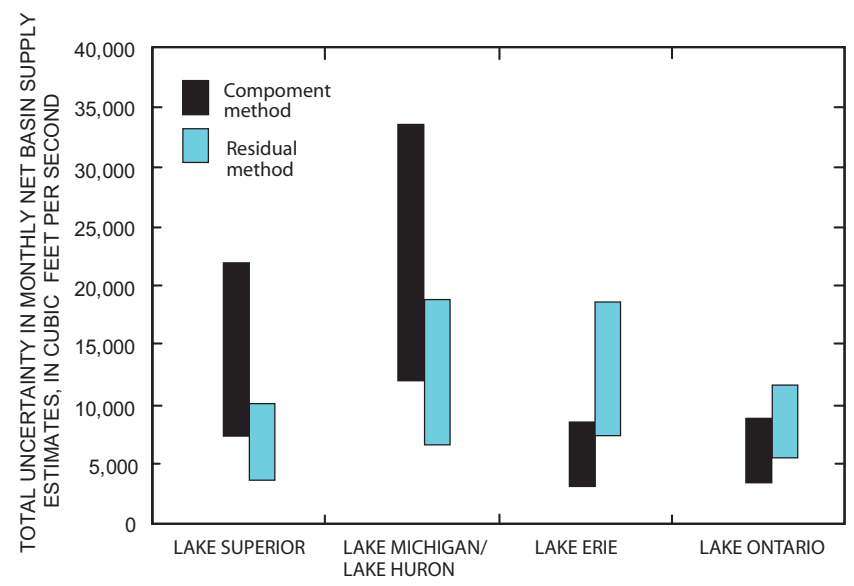

Figure 20. Total uncertainty in monthly net basin supply estimates for each method and each Great Lake, expressed as flow rate.

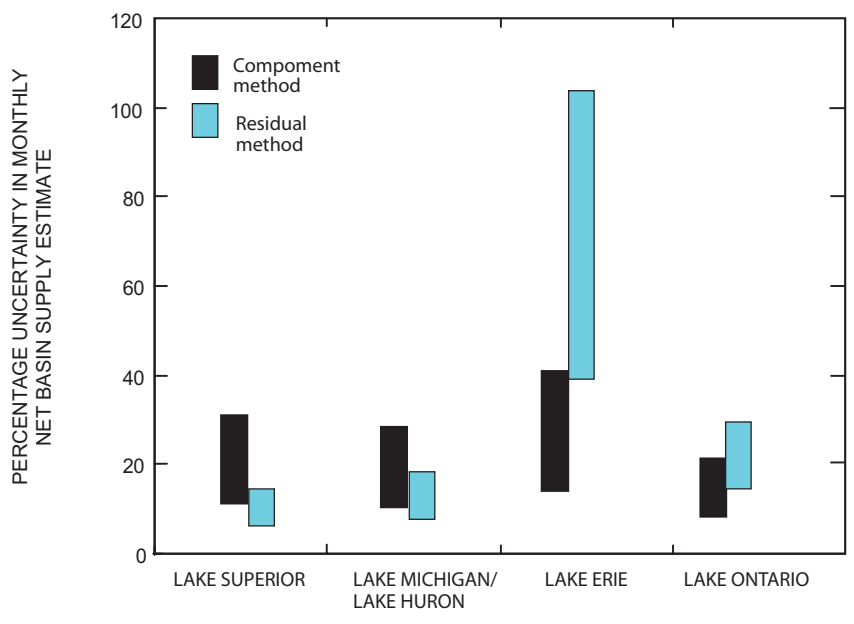

Figure 21. Percentage uncertainty in monthly net basin supply estimates for each method and each Great Lake. nent, according to the methods explained in Hill (1998, p. 46-47). Total uncertainty in NBS estimates is presented both as an amount of flow and as a percent of the long-term average monthly NBS. Percent uncertainty in NBS is given for comparative purposes and should be interpreted with caution. During months with small NBS, the percent uncertainty could be greater than these tables indicate. Likewise, during months with large NBS, the percent uncertainty could be less than these tables indicate.

As these results indicate, each of the two methods used to calculate NBS is better suited to particular situations. The residual method produces NBS estimates with the least amount of uncertainty for Lakes Superior and MichiganHuron. In contrast, the component method of calculating NBS provides the least amount of uncertainty for Lakes Erie and Ontario. There also is a large range in uncertainty for NBS estimates calculated with the two methods. The component method yields NBS estimates for Lake Superior with about $2 \frac{1}{2}$ times greater uncertainty than the residual method does. However, for Lake Erie, the component method yields NBS estimates with less than half the uncertainty of residual NBS estimates.

Table 7a. Summary of net basin supply (NBS) uncertainty, expressed as a percent of long term average monthly NBS.

\begin{tabular}{lrrrr}
\hline & \multicolumn{2}{c}{ Component } & & \\
\multicolumn{1}{c}{ Method } & \multicolumn{2}{c}{ Residual Method } \\
Lake & Low & High & Low & High \\
\hline Superior & 11 & 31 & 4 & 12 \\
Michigan-Huron & 10 & 28 & 5 & 16 \\
Erie & 14 & 41 & 36 & 101 \\
Ontario & 8 & 21 & 12 & 27 \\
\hline
\end{tabular}

Table 7b. Summary of net basin supply (NBS) uncertainty, expressed in cubic feet per second.

\begin{tabular}{lrrrr}
\hline & \multicolumn{2}{c}{ Component } & & \\
\multicolumn{1}{c}{ Method } & \multicolumn{2}{c}{ Residual Method } \\
Lake & Low & High & Low & High \\
\hline Superior & 7,567 & 21,848 & 2,656 & 9,164 \\
Michigan-Huron & 11,766 & 33,479 & 5,630 & 18,084 \\
Erie & 2,871 & 8,417 & 6,412 & 17,991 \\
Ontario & 3,370 & 8,546 & 4,631 & 10,951 \\
\hline
\end{tabular}




\section{Summary and Conclusions}

In June 2001, eight U.S. state governors and two Canadian province premiers signed an Annex to the 1985 Great Lakes Charter. The Annex calls for, among other things, hydrologic data and information to support a new decision standard regarding proposals to withdraw water from the Great Lakes Basin. None of the existing Great Lakes hydrologic monitoring networks were designed to support such a system. An understanding of the limitations of the many monitoring networks in the context of Annex 2001 is both unknown and fundamental to the design and implementation of a successful decision-making standard. This report was written in response to this need, addresses several important questions regarding the status of existing hydrologic monitoring networks, and assesses uncertainty in the Great Lakes water balance.

This report is a product of Technical Subcommittee 2 (TSC2) of the Water Resources Management Decision Support System (WRMDSS) project supported by the Great Lakes Protection Fund, prepared by the U.S. Geological Survey in cooperation with the Great Lakes Commission. TSC2 was charged with providing a status assessment of water-resources information and availability. Most of the work of TSC2 was designed to evaluate the quantity and quality of water-resources data and information on a lakewide or systemwide scale. Specifically, the work and other publications resulting from TSC2 focused on flows and levels in the context of net basin supplies (NBS) to each Great Lake. Additional information is available from two other project reports: "The Great Lakes Water Balance: Data Availability and Annotated Bibliography of Selected References" (Neff and Killian, 2003) and "Great Lakes Monthly Hydrologic Data" (Croley and others, 2001).

This report describes the Great Lakes hydrologic system, and methods used to quantify individual components of the water balance. Specific water-balance components discussed include connecting channel flow, runoff, over-lake precipitation, evaporation, groundwater inputs, change in storage, and diversions in and out of the Great Lakes. Potential sources of uncertainty are identified and, where appropriate, alternate or additional data, models, and estimation methods suitable for reducing uncertainties are discussed. Finally, approximate uncertainties in monthly estimates of all water-balance components are identified and compared within the context of monthly NBS estimates.

Throughout this report, the term "uncertainty" is used qualitatively to describe errors and biases associated with measurements, calculations, and estimates. All measurements and calculations have uncertainty associated with them. Uncertainty does not necessarily indicate errors or flaws in monitoring. In some cases, uncertainty in a measurement or calculation may be present despite state-of-the-art instrumentation or estimation methods. Also, this report discusses uncertainties within the context of monthly data and monthly NBS estimates. This context is used because the Great Lakes water balance is most commonly described on a monthly time scale, and is frequently used to calculate NBS. It is not known if monthly data, or if the concept of NBS, is well suited to the information needs of Annex 2001.

Results indicate that average uncertainties in monthly estimates of individual water-balance components may range from 1.5 percent to 45 percent. This may result in monthly net basin supply uncertainties of approximately $2,600 \mathrm{ft}^{3} / \mathrm{s}$ to $33,500 \mathrm{ft}^{3} / \mathrm{s}$ for individual Great Lakes. These results reflect estimates of uncertainty, rather than an absolute determination of uncertainty. It is not possible to conclusively determine uncertainties in the Great Lakes water balance for two reasons. First, the Great Lakes hydrologic system is highly variable and uncertainty of water-balance estimates is in a constant state of flux. Second, for several reasons it is not possible to conclusively determine uncertainty in estimates of individual components. In some instances, such as evaporation estimates, methods used to estimate a water-balance component preclude an effective assessment of uncertainty. In other cases, such as over-lake precipitation, there is a substantial data gap that prevents effective assessment of uncertainty. A lack of external review among agencies responsible for reporting hydrologic data in the Great Lakes Basin also complicates the determination of uncertainty in water-balance component estimates. Therefore, TSC2 used its best professional judgment to estimate ranges of uncertainty for monthly estimates of levels and flows.

This report identifies several data gaps and information needs that prevent a more conclusive determination of water-balance components. The greatest data gap is a lack of over-lake weather monitoring. Improvements to weather monitoring over the surface of the lakes could help researchers better assess over-lake rainfall and evaporation. A second need is for improvement in wintertime connecting-channelflow estimates, particularly on the St. Clair and Detroit Rivers. Third, improvements in estimates of ungaged basin runoff could reduce the uncertainty of runoff estimates. Fourth, current accounting of interbasin diversions may not properly describe each diversion's impact on the water balance. As data gaps are filled, information needs are met, and external review of hydrologic data increases, uncertainty in estimates of waterbalance components will diminish.

\section{Acknowledgments}

This report is a result of cooperative efforts of members of Technical Subcommittee 2 of the Water Resources Management Decision Support System (WRMDSS) project, who defined the scope of work reported herein, provided substantive data and information, and reviewed all drafts of the report. In addition, members of the Project Management Team and Stakeholder Advisory Committee of the WRMDSS project reviewed and provided comment on drafts of the report. All these people and their agencies contributed significant staff time and other resources to this effort and they are named in the final report of the WRMDSS project, "Toward a Water 
Resources Management Decision Support System for the Great Lakes-St. Lawrence River Basin" (Great Lakes Commission, 2003).

This report has benefited from significant input and collaboration from Dick Bartz (Ohio Department of Natural Resources), Jim Bredin (Michigan Department of Environmental Quality), Andy Buschbaum (National Wildlife Federation), Ian Cameron (Ontario Ministry of Natural Resources), Len Falkiner (Environment Canada), Roger Gauthier (U.S. Army Corps of Engineers), Reg Gilbert (Great Lakes United), James Hebenstreit (Indiana Department of Natural Resources), Dan Injerd (Illinois Department of Natural Resources), Jim Japs (Minnesota Department of Natural Resources), George Kuper (Council of Great Lakes Industries), David Ladd (formerly of Michigan Department of Environmental Quality), Wendy Larson (Limno-Tech), Bob Metcalfe (Ontario Power Generation), Sarah Miller (Canadian Environmental Law Association), Nanette Noorbakhsh (U.S. Army Corps of Engineers), and Chuck Southam (Environment Canada). The assistance and advice of the Great Lakes Commission staff-Dan Blake, Tom Crane, Mike Donahue, and Becky Lameka-has been invaluable. Finally, the authors appreciate the thoughtful technical reviews of Tom Croley (National Oceanic and Atmospheric Administration) and Daniel Feinstein (U.S. Geological Survey), the careful editorial reviews of Mike Eberle and Leah Hout (U.S. Geological Survey), and the illustration and layout work of Sharon Baltusis (U.S. Geological Survey).

\section{References Cited}

Assel, R.A., Quinn, F.H., Leshkevich, G.A., and Bolsenga, S.J., 1983, Great Lakes Ice Atlas: Ann Arbor, Mich., Great Lakes Environmental Research Laboratory, NOAA atlas No. 4.

Blumer, S.P., Behrendt, T.E., Ellis, J.M., Minnerick, R.J., LeuVoy, R.L., and Whited, C.R., 1999, Water resources data, Michigan, water year 1998: U.S. Geological Survey Water-Data Report MI-98-1, 477 p.

Clark, R.H., and Persoage, N.P., 1970, Some implications of crustal movement in engineering planning: Canadian Journal of Earth Sciences, v. 7, p. 628-633.

Coordinating Committee on Great Lakes Basic Hydraulic and Hydrologic Data, 1976, Lake Erie outflow 1860-1964 with addendum 1965-1975: Chicago, Ill., and Cornwall, Ont., $20 \mathrm{p}$.

Coordinating Committee on Great Lakes Basic Hydraulic and Hydrologic Data, 1977, Coordinated Great Lakes physical data: Detroit, Mich., and Burlington, Ont., 12 p.
Coordinating Committee on Great Lakes Basic Hydraulic and Hydrologic Data, 1988, Lakes Michigan-Huron outflowsSt. Clair and Detroit Rivers 1900-1986: Detroit, Mich., and Burlington, Ont., 57 p.

Coordinating Committee on Great Lakes Basic Hydraulic and Hydrologic Data, 1994, Hydraulic discharge measurements and regimen changes on the Great Lakes connecting channels and the international section of the St. Lawrence River - 1841-1993 main report and appendix A: Detroit, Mich., and Burlington, Ont..

Croley, T.E., II, 1987a, Minimizing long-term wind set-up errors in estimated mean Erie and Superior lake levels: Ann Arbor, Mich., Great Lakes Environmental Research Laboratory, NOAA Technical Memorandum ERL GLERL-64, $40 \mathrm{p}$.

Croley, T.E., II, 1987b, Wind set-up error in mean lake levels: Journal of Hydrology, v. 92, p. 223-243.

Croley, T.E., II, 1989a, Lumped modeling of Laurentian Great Lakes evaporation, heat storage, and energy fluxes for forecasting and simulation: NOAA Technical Memorandum ERL GLERL-70, 48 p.

Croley, T.E., II, 1989b, Verifiable evaporation modeling on the Laurentian Great Lakes: Water Resources Research, v. 25, no. 5, p. 781-792.

Croley, T. E., II, 1992, Long-term heat storage in the Great Lakes: Water Resources Research, v. 28, no. 1, p. 69-81.

Croley, T.E., II, 1998, Hydrological scenario development, in Lavender, B., Smith, J.V., Koshida, G., and Mortsch, L.D., eds., Binational Great Lakes-St. Lawrence basin climate change and hydrologic scenarios report: Downsview, Ont., Environment Canada Environmental Adaptation Research Group, chap. 4, p. 45-88.

Croley, T.E., II, and Assel, R.A., 1994, A one dimensional ice thermodynamics model for the Laurentian Great Lakes: Water Resources Research, v. 30, no. 3, p. 625-639.

Croley, T.E., II, and Hartmann, H.C., 1985, Resolving Thiessen polygons: Journal of Hydrology, v. 76, p. 363-379.

Croley, T.E., II, Hunter, T.S., and Martin, S.K., 2001, Great Lakes monthly hydrologic data: NOAA Technical Report TM-083, 13 p. [Update from Croley, T.E. II, and T.S. Hunter, 1994, Great Lakes monthly hydrologic data: NOAA Technical Report \#TM-083, 12 p.]

Derecki, J.A., and Quinn, F.H., 1986, Record St. Clair River ice jam of 1984: Journal of Hydraulic Engineering, v. 112, no. 12 , p. 1182-1194.

Eichenlaub, V.L., 1979, Weather and climate of the Great Lakes region: Notre Dame, Ind., University of Notre Dame Press, $335 \mathrm{p}$. 
Environment Canada, The atlas of Canada: Ottawa, Ontario, accessed on September 30, 2003, at URL http://atlas.gc.cal sitelenglish/facts/lakes.html\#OM

Government of Canada and U.S. Environmental Protection Agency, 1995, The Great Lakes-An environmental atlas and resource book ( $3^{\text {rd }}$ ed.): Toronto, Ont., and Chicago, Ill., $46 \mathrm{p}$.

Grannemann, N.G., and Weaver, T.L., 1999, An annotated bibliography of selected references on the estimated rates of direct ground-water discharge to the Great Lakes: U.S. Geological Survey Water-Resources Investigations Report 98-4039, 24 p.

Great Lakes Commission, 2003, Toward a water resources management decision support system for the Great LakesSt. Lawrence River basin-Status of data and information on water resources, water use, and related ecological impacts: Great Lakes Commission, Ann Arbor, Mich., 142 p.

Groisman, P.Y., and Legates, D.R., 1994, The accuracy of United States precipitation data: Bulletin of the American Meteorological Society, v. 75, no. 3, p. 215-217.

Hill, M.C., 1998, Methods and guidelines for effective model calibration: U.S. Geological Survey Water-Resources Investigations Report 98-4005, 90 p.

Holtschlag, D.J., and Koschik, J.A., 2001, A two-dimensional hydrodynamic model of the St. Clair and Detroit Rivers within the Great Lakes Basin: U.S. Geological Survey Water-Resources Investigations Report 01-4236, 60 p.

International Joint Commission, 1985, Great Lakes diversions and consumptive uses - a report to the governments of the United States and Canada under the 1977 Reference: Ottawa, Ontario and Washington DC, 82p.

International Joint Commission, 1999, Protection of the waters of the Great Lakes: Ottawa, Ont., and Washington, D.C., $40 \mathrm{p}$.

International Lake Superior Board of Control, 2001, SemiAnnual Progress Report to the International Joint Commission Covering the period September 14, 2000 to March 7, 2001, International Joint Commission, Washington and Ottawa.

International Lake Superior Board of Control, 2002, SemiAnnual Progress Report to the International Joint Commission Covering the period September 21, 2001 to March 18, 2002, International Joint Commission, Washington and Ottawa.

International Lake Superior Board of Control, 2003, SemiAnnual Progress Report to the International Joint Commission Covering the period March 5, 2003 to September 15, 2003, International Joint Commission, Washington and Ottawa, $10 \mathrm{p}$.
International Niagara Working Committee, 2001, Report to the International Niagara Board of Control on the 2000-2001 operation of the Lake Erie-Niagara River Ice Boom: Buffalo, N.Y., and Burlington, Ont., 14 p.

Larsen, C.E., 1987, Geological history of Glacial Lake Algonquin and the upper Great Lakes: U.S. Geological Survey Bulletin 1801, 36 p.

Lee, D.H., 1992. Computation of net basin supplies-A comparison of two methods, in International Joint Commission levels reference study: Ann Arbor, Mich., Great Lakes Environmental Research Laboratory, Final Report Subtask 19.1.2a, $18 \mathrm{p}$.

Legates, D.R., and DeLiberty, T.L., 1993, Estimates of biases in precipitation gage measurements-An example using the United States raingage network, in Groisman, P.Y., and Legates, D.R., eds., 1994, Proceedings from the eighth symposium on meteorological observations and instrumentation: Anaheim, Calif., American Meteorological Society. J48-J51, figure 1, p. 219.

Manninen, C., and Gauthier, R., 1999, Living with the lakesUnderstanding and adapting to Great Lakes water level changes: Ann Arbor, Mich., and Detroit, Mich., Great Lakes Commission and U.S. Army Corps of Engineers, 39 p.

Meredith, D.M., 1975, Temperature effects on Great Lakes water balance studies: Water Resources Bulletin, v. 11, no. 1, p. 60-68.

Neff, B.P., and Killian, J.R., 2003, The Great Lakes water balance: data availability and annotated bibliography of selected references: U.S. Geological Survey WaterResources Investigations Report 02-4296, 37 p.

Quinn, F.H., 1988, Detroit River flow reversals: Journal of Great Lakes Research, v. 14, no. 4, p. 383-387.

Quinn, F.H., 1979, Relative accuracy of connecting channel discharge data with application to Great Lakes studies: Journal of Great Lakes Research, v. 5, no. 1, p. 73-77.

Quinn, F.H., and Derecki, J.A., 1990, Comparison of measured and simulated flows during the 15 December 1987 Detroit River flow reversal: Journal of Great Lakes Research, v. 16, no. 3 , p. 426-435.

Quinn, F.H., and Guerra, B., 1986. Current perspectives on the Lake Erie water balance: Journal of Great Lakes Research. v. 12 no. 2 , p. $109-116$.

Quinn, F.H., and Kelly, R.N., 1983. Great Lakes monthly hydrologic data: NOAA Data Report ERL GLERL-26, 79 p.

Rantz, S.E., and others, 1982, Measurement and computation of streamflow: U.S. Geological Survey Water-Supply Paper 2175, v. 2., 631 p. 
U.S. Army Corps of Engineers, 2001, Lake Michigan diversion accounting water year 1998 annual report: Chicago District, $11 \mathrm{p}$.

Winter, T.C., Rosenberry, D.O., and Sturrock, A.M., 1995, Evaluation of 11 equations for determining evaporation for a small lake in the north central United States: Water Resources Research, v. 31, no. 4, p. 983-993.

Xu, C-Y., and Singh, V.P., 1998, A review on monthly water balance models for water resources investigations: Water Resources Management, v. 12, p. 31-50. 


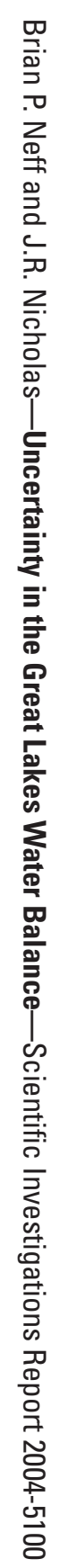

9 Printed on recycled paper 